Portland State University

PDXScholar

Summer 8-29-2016

\title{
A Landscape Approach to Determining and Predicting Juvenile Coho Salmon (Oncorhynchus kisutch) Movement Timing and Growth Patterns Prior to Ocean Entry
}

Amelia Lee Johnson

Portland State University

Follow this and additional works at: https://pdxscholar.library.pdx.edu/open_access_etds

Part of the Aquaculture and Fisheries Commons, and the Environmental Sciences Commons Let us know how access to this document benefits you.

\section{Recommended Citation}

Johnson, Amelia Lee, "A Landscape Approach to Determining and Predicting Juvenile Coho Salmon (Oncorhynchus kisutch) Movement Timing and Growth Patterns Prior to Ocean Entry" (2016).

Dissertations and Theses. Paper 3155.

https://doi.org/10.15760/etd.3149

This Thesis is brought to you for free and open access. It has been accepted for inclusion in Dissertations and Theses by an authorized administrator of PDXScholar. Please contact us if we can make this document more accessible: pdxscholar@pdx.edu. 
A Landscape Approach to Determining and Predicting Juvenile Coho Salmon

(Oncorhynchus kisutch) Movement Timing and Growth Patterns Prior to Ocean Entry

\title{
by
}

Amelia Lee Johnson

A thesis submitted in partial fulfillment of the requirements for the degree of

\author{
Master of Science \\ in \\ Environmental Science and Management
}

Thesis Committee:

Angela Strecker, Chair

Michael T. Murphy

Mariska Obedzinski

Portland State University

2016 


\section{Abstract}

Coho salmon (Oncorhynchus kisutch) rely on unique habitats during the winter season, which may dictate how much individuals may growth and when migration from freshwater rearing habitat to the ocean occurs. Here I analyze movement timing and growth patterns for coho salmon through a field-based study and a literature review. For the field portion, I examined hatchery-stocked juvenile coho salmon across four stream basins in the Russian River watershed, California to determine the relative importance of climate, landscape, and fish size metrics in predicting movement and growth patterns over a winter rearing and spring smolt outmigration time period (December 2014 - June 2015). I observed three unique movement strategies: winter parr movement, spring smolt movement, and inter-tributary movement. Movement was predicted in relation to daily temperature and precipitation, followed by in-stream and upslope basin conditions in random forest modeling. Specifically, fish that moved later were associated with basins that contained higher productivity and low-gradient floodplain habitats, while fish that moved earlier came from streams that lacked invertebrate prey and had limited lowgradient rearing habitat. Fish size and timing of movement were the primary predictors of growth, with relatively larger fish in the spring growing faster than fish that were relatively smaller prior to winter. These relationships suggest that hatchery-release fish are still highly influenced by environmental conditions once released, especially in terms of initial seasonal movement, and that watershed conditions should be considered when utilizing hatchery-rearing programs to supplement wild fish populations. 
In North America, coho salmon populations are distributed from Alaska through California, and may exhibit unique movement and growth patterns in relationship to population-scale vulnerability (Endangered Species Act listing), basin area, and availability and types of rearing habitat. For the second part of my thesis, I conducted a literature review to assess what factors are commonly considered in predicting movement and growth patterns for these fish, as well as the types (season and life stage) and number of movement strategies reported. Eighteen studies were summarized, of which sixteen identified unique movement strategies, ranging from one to four. Despite a wide range of basin areas and latitudes, winter parr and spring smolt movements were commonly observed, with authors primarily relating these behaviors to in-stream habitat and fish size metrics. Additionally, growth was linked positively and primarily with off-channel winter rearing, which may outweigh the importance of fish size in predicting growth when high quality rearing habitats are available during the winter season.

Recognizing movement timing diversity and its drivers can help recover threatened coho salmon populations. More widely distributed populations may have unique phenotypic expressions based on localized genetic and environmental interactions, increasing diversity and overall stability across the population, a concept known as the portfolio effect. Understanding fish-habitat relationships can aid recovery efforts by providing a framework of climatic and watershed conditions that support unique behaviors, even in already severely limited populations. 


\section{Acknowledgements}

This project would not have been possible without generous support from many. I would foremost like to thank my adviser Angela Strecker, for not just offering guidance through graduate school, but for helping me become a better scientist. I would also like to thank my committee members Michael T. Murphy and Mariska Obedzinski for their guidance and support through this process. Additionally, Alan Yeakley took the time to meet and discuss many aspects of this research, and my lab mates Ariana Chiapella, Sam Cimino, Tim Elder, Crysta Gantz, Meredith Holgerson, Meredith Jordan, and Brian McGann, as well as my graduate cohort, all offered encouragement and constructive feedback throughout the research process. California Sea Grant, the Center for Lakes and Reservoirs, and Portland State University all provided financial support, and Portland State University Environmental Science and Management Department staff provided wonderful administrative assistance.

Data collection and analysis would not have been possible on my own. The staff, volunteers, and AmeriCorps members with the Russian River Coho Salmon Captive Broodstock Program were essential to this research: they monitored and collected the salmon data utilized in this project as well as assisted with research design, invertebrate and habitat data collection, and provided equipment and office support. I would also like to thank Oliviah Franke, Kim Hack, and Steve Wells for their enthusiasm and assistance with invertebrate laboratory work. 
Finally, getting to and making it through graduate school would not have been possible with the support of family, friends, and mentors along the way. All provided incredible moral support through the process, and I could not have done it without them. 


\section{Table of Contents}

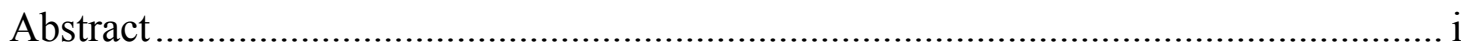

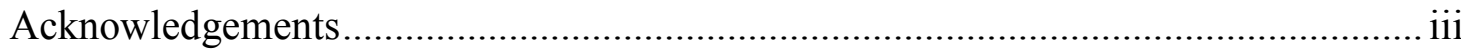

List of Tables ................................................................................................... vii

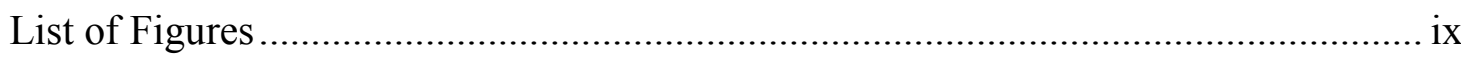

Chapter $1:$ Introduction ......................................................................................... 1

Chapter 2 : Landscape and fish size predictors of juvenile coho salmon (Oncorhynchus

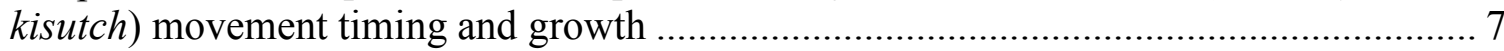

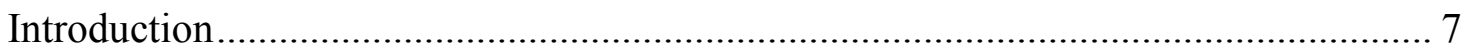

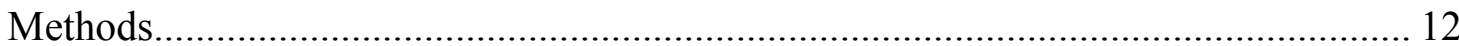

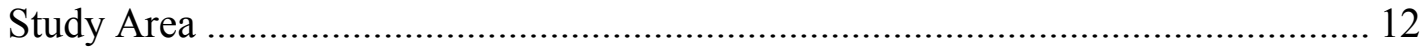

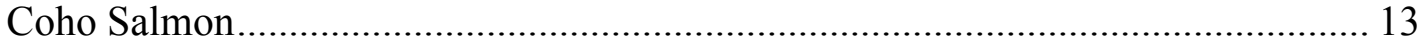

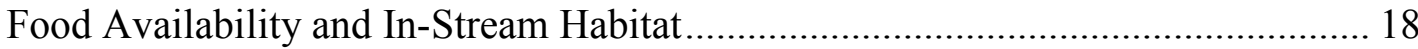

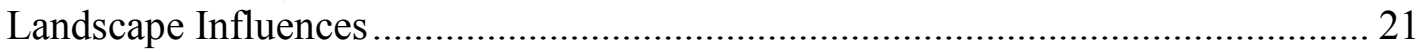

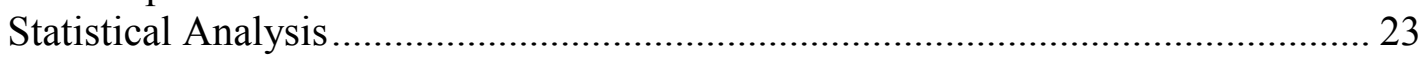

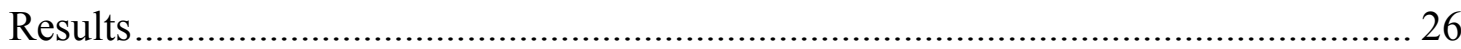

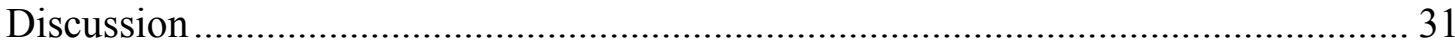

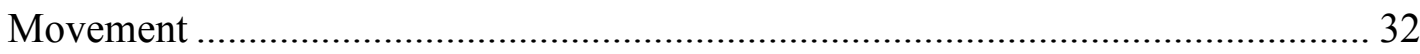

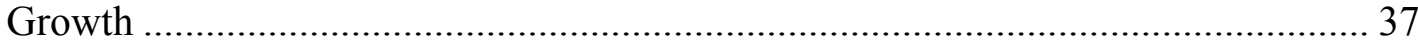

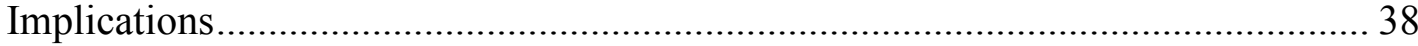

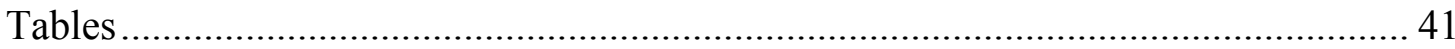

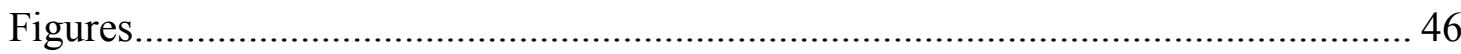

Chapter 3 : Documenting diversity: Evidence of multiple life history strategies across the

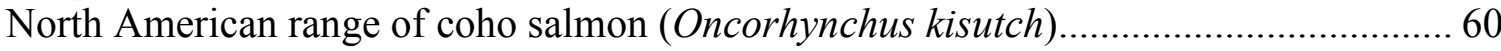

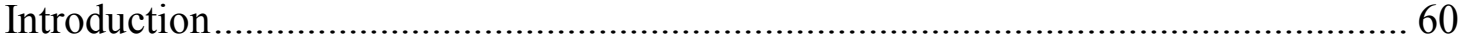

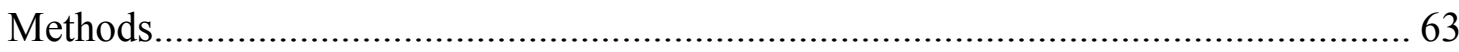

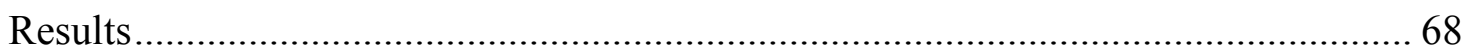

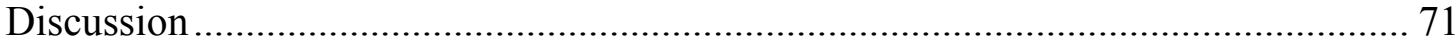

Commonalities and Gaps in Knowledge .................................................... 71

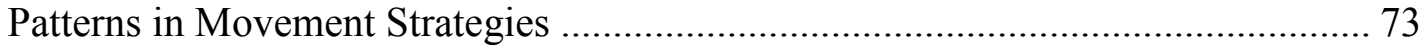

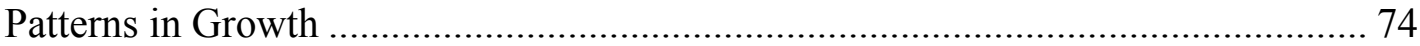

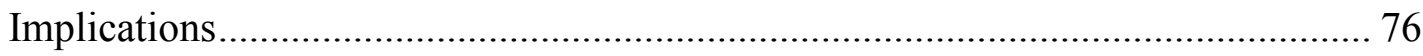

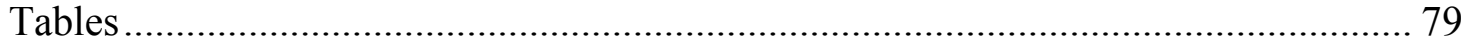

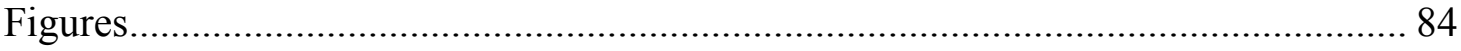

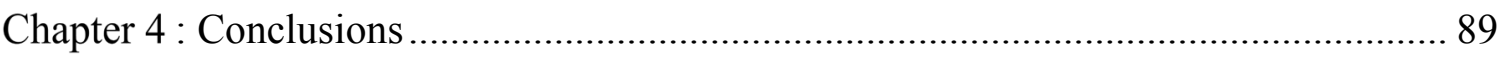

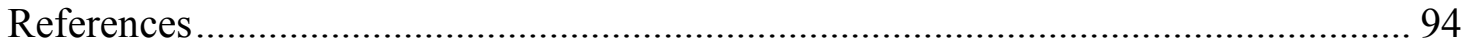

Appendix A: PIT antenna site design and detection metrics ............................... 106

Appendix B: Landscape and in-stream habitat methods and data summaries........... 107 
Appendix C: PCA supporting data for Chapter 2 and Chapter 3 results .................. 115

Appendix D: Random forest model supporting data ............................................ 121

Appendix E: Directional classification supporting data ....................................... 122 


\section{List of Tables}

Table 2.1. Summary statistics for release groups per study stream, including mean and standard deviation of pre-winter fish size variables. All measurements were completed at the hatchery during the measurement date range. Release date is when fish were released into each study stream. $\mathrm{K}=$ (pre-winter wet weight $(\mathrm{g}) * 100$ ) / (pre-winter absolute fork length (mm)) (Weatherley and Rogers 1978). $\mathrm{MN}=$ Mean, $\mathrm{SD}=$ Standard Deviation, FL $=$ fork length, $\mathrm{K}=$ Condition factor, DUT $=$ Dutch Bill Creek, GRE $=$ Green Valley Creek, MIL $=$ Mill Creek, WIL $=$ Willow Creek.

Table 2.2. Summary statistics by landscape and in-stream variable type across all basin types $(\mathrm{n}=11)$. Methods in Appendix B. SPC = Slope Position Classification, TWI = Topographic Wetness Index, $\mathrm{SD}=$ standard deviation, $\mathrm{BMI}=$ benthic macroinvertebrate abundance, Dev. $=$ Development, $\mathrm{CV}=$ coefficient of variation . 42

Table 2.3. Summary statistics for the subset of fish detected per release group, where fish size variables are from pre-winter measurements. All detected individuals were measured at the hatchery prior to release into each study stream. No upstream detections are recorded for DUT since only one PIT antenna site was present. $\mathrm{MN}=$ Mean, $\mathrm{SD}=$ Standard Deviation, $\mathrm{FL}=$ fork length, $\mathrm{K}=$ Condition factor, Det. = Detection, $\mathrm{DUT}=$ Dutch Bill Creek, GRE = Green Valley Creek, MIL = Mill Creek, WIL = Willow Creek.

Table 2.4. Summary statistics for the subset of fish recaptured at spring migrant traps per original release group. All pre-winter measurements were taken at the hatchery prior to release in each study stream and all spring measurements took place at the spring migrant smolt traps. $\mathrm{PW}=$ pre-winter measurement, $\mathrm{MN}=$ Mean, $\mathrm{SD}=$ Standard Deviation, $\mathrm{FL}=$ fork length, Weight $=\mathrm{WT}, \mathrm{K}=$ Condition factor, Rel. $=$ Relative, $\mathrm{GR}=$ growth rate, $\mathrm{DUT}$ $=$ Dutch Bill Creek, GRE $=$ Green Valley Creek, MIL = Mill Creek, WIL = Willow Creek.

Table 2.5. Random forest regression model summaries.

Table 3.1. Variable descriptions utilized in principle component analysis (PCA). Not all variables used in all analyses: rearing habitat effect used separately from pre-winter fork length effect. Binary variables are based on whether or not that study included that variable. Effects are based on significance of variable: positive effect (1), negative effect $(0)$, or no significant effect $(0.5)$ on response variable.

Table 3.2. Summary of study locations, population characteristics, and study timelines, organized north to south based on basin mouth latitude $(n=18)$. Study years listed are for the beginning year (fall) rather than the end of a study year (spring). If multiple basins were included in a study, latitude and basin area values listed are the mean, and population status is for the most vulnerable population. Land use includes historical and current practices. Precip = Precipitation, $\mathrm{R}=$ Rain, $\mathrm{SN}=$ Snowmelt, GL = glacier-melt, Pop. $=$ Population, $\mathrm{NL}=$ Not listed, $\mathrm{SC}=$ Species of Concern, $\mathrm{Th}=$ Threatened.. 
Table 3.3. Potential drivers of movement and/or growth patterns considered per study. $\mathrm{X}$ 's equate to yes and blank cells equate to no, studies organized north to south based on basin mouth latitude, as in Table $3.2(\mathrm{n}=18)$.

Table 3.4. Rearing habitat types documented per movement study, with mean and standard deviation of noted unique juvenile life histories leading to smolt outmigration (n $=17)$. 


\section{List of Figures}

Figure 2.1. The four study stream basins in the Russian River watershed, northern California. Upslope influences on detection sites are delineated per upstream and downstream detection site. Main stem tributaries (Dry Creek and Russian River) are labeled.

Figure 2.2. Diagram of PIT detection and in-stream sampling reach distribution across a stream. Paired antennas improve detection efficiency per site, and were used as the site design for all but one site in this study, the GRE upstream basin detection site. Macroinvertebrate and in-stream physical habitat measurements were composited per habitat unit and across four reaches per study stream to represent microhabitat and reachscale variability. Physical habitat metrics were collected to represent the whole habitat unit, and were thus not collected only at microhabitat sampling points.

Figure 2.3. Distribution of all detected individuals pre-winter (a) absolute fork length ( $\log _{10}$-transformed), (b) pre-winter Condition factor, and (c) pre-winter relative fork length $(\mathrm{n}=1779)$ among the four study streams. Boxplots denote the median value with the box limits extending to the upper (75th percentile) and lower (25th percentile) quartiles. Whiskers extend 1.5 times beyond the interquartile distance of the median, with observations beyond these extents represented as open circles. Letters above study streams represent significantly different pairwise comparisons $(p<0.05)$. 48

Figure 2.4. Individual fish movement day past (a) upstream detection sites $(\mathrm{n}=1291)$ and (b) downstream detection sites $(n=1246)$. Counts are grouped by week-long intervals (gray bars), with day 1 occurring on December 10, 2015 (month included below movement days). Total daily precipitation $(\mathrm{mm})$ per movement day is included for reference (black line).

Figure 2.5. Individual fish movement day past (a) upstream detection sites (three streams, $\mathrm{n}=1291$ ) and $(\mathrm{b})$ downstream detection sites (four streams, $\mathrm{n}=1246$ ). Box and whiskers as in Figure 3. Letters above study streams represent significantly different pairwise comparisons $(p<0.05)$.

Figure 2.6. Individual movement day past downstream detection sites for inter-stream detected fish (three streams, $\mathrm{n}=42$ ) and intra-stream detected fish (four streams, $\mathrm{n}=$ 1246). Movement day is the maximum movement day past downstream detection sites for intra-stream group, and minimum movement day past downstream detection sites for inter-stream groups. Box and whiskers as in Figure 3. Letters above study streams represent significantly different pairwise comparisons $(p<0.05)$.

Figure 2.7. Distribution of (a) absolute fork length (log10-transformed), (b) relative fork length, and (c) growth rate $(\mathrm{n}=219)$ of all spring recaptured individuals among the four study streams. Box and whiskers as in Figure 3. Letters above study streams represent significantly different pairwise comparisons $(p<0.05)$. 52

Figure 2.8. PCA for all basin-scale landscape variables across the three basin types. Site scores are indicated by symbols representing basin type (circle = downstream, triangle = entire basin, square=upstream) and stream name. In-stream variable labels and vectors 
are in blue, vegetation in green, geomorphology in brown, and agriculture and development in red. Full variable descriptions in Appendix B. Abbreviations for instream variables on figure are: mean benthic invertebrate abundance (MN BMI), standard deviation of mean benthic invertebrate abundance (SD BMI), mean in-stream shelter rating (MN Shelter), coefficient of variation of mean in-stream shelter rating (CV Shelter), coefficient of variation in wetted width (CV WW), coefficient of variation in bankfull width (CV BF), coefficient of variation in ratio of wetted width to bankfull width (CV WW:BF). Abbreviations for vegetation on figure are mean \% coverage of: canopy coverage (MN CC), conifer trees (Conifer Forest), deciduous trees (Deciduous Forest), mixed trees (Mixed Forest), herbaceous plants (Herbaceous), shrub and scrub (Shrub), wooded wetlands (Wooded Wetland), herbaceous wetlands (Herbaceous Wetland), bare ground (Barren Land). Abbreviations for geomorphology variables on figure are: Slope (MN Slope, Slope Position Classification Valley (SPC Valley), Low Slope (SPC Low), Flat Slope (SPC Flat), Middle Slope (SPC Mid), Upper Slope (SPC Upper), Ridge (SPC Ridge), Mean Basin Topographic Wetness Index (MN TWI), Standard Deviation of Mean Topographic Wetness Index (SD TWI). Abbreviations for agriculture and development variables on figure are \% cover: open space development (Dev. Open Space), low intensity development (Dev. Low), medium intensity development (Dev. Med), high intensity development (Dev. High), cropland (Cultivated Crops), and impervious surface (Impervious).

Figure 2.9. Variable importance values for upstream movement day random forest model $(\mathrm{n}=1291)$. Variable importance is scaled (mean decrease in model accuracy percentage/standard deviation). Variable name is listed on the $\mathrm{x}$-axis with variable types included on the right-hand side. Variable names included basin type when multiple basins are included in the model for that variable. $\mathrm{K}=$ Condition factor, $\mathrm{FL}=$ fork length, $\mathrm{US}=$ upstream, $\mathrm{DS}=$ downstream, $\mathrm{PC}=$ principal component. 54

Figure 2.10. Partial dependence plot for upstream movement day versus the four most important non-watershed variables $(n=1291)$. a) Upstream daily temperature (degrees Celsius), b) Upstream basin daily precipitation ( $\mathrm{mm})$, c) Pre-winter relative fork length, d) Pre-winter Condition factor. Partial dependence plots depict the impact of one predictor on the response if all other predictors are held constant. 55

Figure 2.11. Variable importance values downstream movement random forest model (n $=758$ ). Variable importance is scaled (mean decrease in model accuracy percentage/standard deviation). Variable names are listed on the $\mathrm{x}$-axis with variable types included on the right-hand side. Variable names included basin type when multiple basins are included in the model for that variable. $\mathrm{FL}=$ fork length, $\mathrm{K}=$ Condition factor, $\mathrm{US}=$ upstream, $\mathrm{DS}=$ downstream, $\mathrm{PC}=$ principal component. 56

Figure 2.12. Partial dependence plot for downstream movement day versus the most important variable (a) through the fourth most important variable (d) $(n=758)$, where a) Upstream movement day, b) Daily downstream basin temperature (degrees Celsius), c) Daily Downstream basin precipitation $(\mathrm{mm})$, d) Daily Upstream basin temperature (degrees Celsius). Partial dependence plots depict the impact of one predictor on the response if all other predictors are held constant. 
Figure 2.13. Variable importance values for the growth rate random forest model $(\mathrm{n}=$ 219). Variable importance is scaled (mean decrease in model accuracy percentage/standard deviation). Variable names are listed on the $\mathrm{x}$-axis with variable types included on the right-hand side. Variable names included basin type when multiple basins are included in the model for that variable. $\mathrm{FL}=$ fork length, $\mathrm{K}=$ Condition factor, $\mathrm{US}=$ upstream, $\mathrm{DS}=$ downstream, $\mathrm{PC}=$ principal component. 58

Figure 2.14. Partial dependence plot for growth rate $(\mathrm{mm} /$ day) versus the most important variable (a) through the fourth most important variable $(d)(n=219)$, where a) pre-winter relative fork length $(\mathrm{mm}), \mathrm{b}$ ) spring relative fork length $(\mathrm{mm}), \mathrm{c})$ downstream movement day, and d) pre-winter Condition factor (ratio of forklength $(\mathrm{mm})$ to body weight $(\mathrm{g})$. .. 59

Figure 3.1. Basin mouth locations and names of the reviewed studies $(n=18)$. .84

Figure 3.2. Directional effects noted across studies for environmental, fish size, and population effects on movement timing. Effect indicates a significant relationship from a reviewed study $(p<0.05)$. A positive effect on movement indicates that as a predictor variable increases in quantity or quality, it is associated with an increase in movement timing, or later (spring) season movement. A negative effect on movement indicates that as a predictor variable increases in quantity or quality, it is associated with a decrease in movement timing, or earlier (winter) seasonal movement $(\mathrm{n}=16)$. 85

Figure 3.3. Directional effects noted across studies for environmental variables, fish size, and population effects on growth. Effect indicates a significant relationship from a reviewed study $(p<0.05)$. A positive effect on growth indicates that as a predictor variable increases in quantity or quality, it is associated with an increase in growth. A negative effect on growth indicates that as a predictor variable increases in quantity or quality, it is associated with a decrease in growth $(\mathrm{n}=16)$.

Figure 3.4. Standardized PCA results for habitat effect on movement strategy $(\mathrm{n}=16)$. Studies are grouped by non-main channel rearing habitat type (main channel when no non-main channel rearing identified). Shortened vector names are Off-Ch $=$ Off-Channel habitat, $\mathrm{ESA}=$ Endangered Species Act listing, $\mathrm{NL}=\mathrm{ESA}$ Not Listed, $\mathrm{SC}=\mathrm{ESA}$ Species of Concern, $\mathrm{Th}=\mathrm{ESA}$ Threatened, Strategies $=$ number of unique movement strategies per study, Main Channel $=$ Main-channel rearing, Trib $=$ tributary-rearing, $\mathrm{P} / \mathrm{L}=$ pond or lake rearing. 87

Figure 3.5. Standardized PCA results for initial fish fork length statistical effect on growth $(\mathrm{n}=8)$. Studies are grouped by non-main channel rearing habitat type (main channel when no non-main channel rearing identified). Shortened vector names are ESA $=$ Endangered Species Act listing, $\mathrm{SC}=\mathrm{ESA}$ Species of Concern, Th $=$ ESA Threatened, Main Channel $=$ Main-channel rearing, $\mathrm{GR}=$ Growth rate, $\mathrm{FL}=$ fish fork length. ......... 88 


\section{Chapter 1 : Introduction}

Freshwater ecosystems support unique and diverse ecological communities as well as provide a multitude of ecosystems services. Human communities rely on freshwater systems to provide drinking and irrigation water, flood buffering, and habitat for commercial fish species while terrestrial and aquatic communities benefit from freshwater food, shelter, and nutrient cycling. However, freshwater systems are some of

the most threatened ecosystems globally (Dudgeon et al. 2006), and a disproportionately large number of aquatic species are considered vulnerable or imperiled (Strayer and Dudgeon 2010). In the United States alone, $47 \%$ of rivers and streams are considered impaired or threatened (United States Environmental Protection Agency 2009), which impacts wildlife by reducing quality habitat and increasing competition for limited resources.

Conserving and restoring freshwater habitat requires an understanding of the spatial- and temporal-scale of influences on physical habitat characteristics (Roni et al. 2008, Bernhardt and Palmer 2011). Large-scale processes, like climate and geologic patterns, influence stream valley gradients and vegetation communities, which in turn influence stream habitat, forming a hierarchical ecosystem structure (Frissell et al. 1986, Montgomery 1999). In-stream habitat patch types and connectivity evolve constantly too, due to seasonal patterns in precipitation and temperature, as well as disturbance events like floods and droughts. These factors affect stream flow regimes, and thus habitat quality and connectivity, establishing shifting habitat mosaics across watersheds (Stanford et al. 2005). 
Habitat connectivity is especially important for highly mobile lotic fish, which must access different habitats to complete their life histories (Schlosser and Angermeier 1995, Fausch et al. 2002). This is especially true for Pacific salmon (Oncorhynchus spp.), which evolved and adapted to the highly dynamic Pacific coastal watersheds, where tectonic activity, fires, landslides, and seasonal climate and productivity patterns all influenced population phenotypic trait persistence (Waples et al. 2008). Natural watershed barriers led to isolation, and the strong tendency of salmon spawners to home to natal streams continually reinforces local adaptations, including timing of spawn and smolt outmigration (Quinn 2005, Waples et al. 2008). Local adaptations extend across a wide geographic range as well. Anadromous Pacific salmon populations occur across the North Pacific from Japan, across Russia, and down western North America. The wide range of marine and freshwater productivities encountered further increases the life history diversity of salmonids (National Research Council 1996, Quinn 2005).

Most Pacific salmon species are anadromous, meaning juvenile fish hatch and rear in freshwater prior to migrating to the ocean, where they grow and mature before returning to stream habitat to spawn (Groot et al. 1995, Quinn 2005). Life history variation occurs among Pacific salmon species due to different life stage residency periods, spatial locations of juvenile rearing, timing of outmigration to the ocean, and spawn timing and size of returning adults (Waples et al. 2001). Life stage transitions are related to fish size and fitness, which in turn are determined by energy available for growth (Dodson et al. 2013, Sloat et al. 2014). Growth is determined by metabolic rate and activity costs, which are governed by temperature, prey caloric quality, and activity 
demands (Hansen et al. 1993, Sloat et al. 2014). Specific to juvenile salmon, foraging and swimming energetic costs are important, and differ based on stream velocity, competition, and predator and prey densities (Fausch 1984, Nielsen 1992, Rosenfeld et al. 2005). Consequently, long-distance movement is influenced by environmental conditions, as individuals maximize their ability to compete for limited resources and reach maturation condition and size, rather than being simply a genetic-controlled response (Olsson et al. 2006).

Freshwater habitat degradation often results in loss of unique habitat types, with low and high gradient streams disproportionately degraded in freshwater systems, reducing estuary, floodplain and ephemeral stream quantity and quality (McClure et al. 2008). Pacific salmon that rely on freshwater habitat for extensive time periods are also disproportionately endangered and threatened compared to salmon that spend more time in marine environments (National Research Council 1996). Climate change is predicted to alter natural stream flow and thermal regimes, further degrading and disconnecting freshwater systems (Meyer et al. 1999, Gibson et al. 2005).

Multiple studies have documented the importance of low and high gradient habitat to juvenile salmonids due to the unique thermal, stream flow, and foraging opportunities that exist there compared to main channel streams. Floodplains provide warmer temperatures, slower stream flows, and greater growth opportunities for fish than main channel stream habitat during winter storm inundation due to their low slope and wetland and riparian forest communities (Sommer et al. 2001, Bellmore et al. 2013). Estuaries are often highly productive environments in comparison to streams because 
warmer estuary temperatures provide high quality growth opportunities for juvenile salmonids (Satterthwaite et al. 2012, Craig et al. 2014). Ephemeral, upper watershed tributaries can also provide high quality habitat to juvenile salmonids when seasonally connected, potentially because of lower resource competition (Wigington et al. 2006).

Life history diversity can increase population resiliency through greater phenotypic trait expression. This is due to greater variation among sub-populations within a population leading to more stability in the overall population, or the portfolio effect (Doak et al. 1998, Tilman et al. 1998). For instance, high annual variability in spawn timing among the many Bristol Bay, Alaska sockeye salmon populations led to a high degree of stability across this large system (Schindler et al. 2010). Greater variability in spatial and temporal habitat use can improve population stability by reducing the impact of localized environmental and biological stressors, like droughts, landslides, or densitydependent factors. Life history diversity relies in part on habitat heterogeneity and the persistence of populations that utilize these unique habitats (Hilborn et al. 2003, Beechie et al. 2006, Waples et al. 2009). Life history diversity is already at risk for Pacific salmon: it is estimated that between 16 and $40 \%$ of historical populations are lost across the North American range, especially in interior and southern basins (National Research Council 1996, Gustafson et al. 2007). Additionally, it is estimated that these local population extinctions have resulted in between a 15 and $33 \%$ decline in phenotypic diversity, quantified as habitat, life history, and genetic variability (Gustafson et al. 2007). 
Increased stability due to life history diversity in spawning adult salmon is well documented in pristine populations (Greene et al. 2010, Schindler et al. 2010) as well as the loss of stability in vulnerable populations (Moore et al. 2010, Carlson et al. 2011). Juvenile life history diversity is also of concern however because most juvenile Pacific salmon rely on freshwater habitat for growth prior to marine residency, and thus population success. Diversity in spatial and temporal habitat use by juvenile fish is especially important for coho salmon $(O$. kisutch), which rely on freshwater and estuarine habitat for one to two years prior to their marine life stage (Shapovalov and Taft 1954, Sandercock 1991). Anthropogenic impacts, including freshwater habitat degradation, have already extirpated or reduced coho salmon populations (Brown et al. 1994, Gustafson et al. 2007). Due to their extensive population loss and lengthy freshwater rearing, many monitoring and restoration activities are focused on coho salmon recovery. This recovery infrastructure and life history strategy make coho salmon an excellent case study to analyze how freshwater habitat distribution relates to population dynamics.

I have two main objectives with this thesis. First, through a field-based study, I will analyze pre-smolt outmigration movement and growth patterns in a southern, hatchery-stocked coho salmon population, examining how these patterns relate to fish size and stream landscape characteristics (Chapter Two). Second, I will consider similarities and differences among coho salmon populations with regards to movement, growth, and their biological and environmental drivers through a literature review (Chapter Three). This literature review will synthesize our understanding of winter and spring pre-smolt migration movement and growth patterns for coho salmon across their 
North American range, as well as consider future research and management actions to conserve and support juvenile movement and growth diversity. 


\section{Chapter 2 : Landscape and fish size predictors of juvenile coho salmon (Oncorhynchus kisutch) movement timing and growth}

\section{Introduction}

Highly mobile populations pose unique problems for conservation and habitat restoration planning, due to the importance of multiple habitats and connections over the life span of these species. This is true for Pacific salmon (Oncorhynchus spp.), a highly mobile fish genus that relies upon freshwater, estuary, and marine habitat to complete their anadromous life history (Groot et al. 1995, Quinn 2005). Mobility across freshwater systems is especially important due to the diversity of habitat types and connections utilized by Pacific salmon over their residency and to complete their life cycle. Many Pacific salmon species, especially in the interior and southern extents of their range, are listed under the Endangered Species Act, some for more than twenty years. Freshwater habitat degradation is considered one of the main reasons for these population declines and lack of recovery (Nehlsen et al. 1991, National Research Council 1996).

Despite a solid understanding in the scientific community of the importance of habitat complexity to Pacific salmon survival, the study of temporal and spatial diversity of habitat use by these fish is still a work in progress. Temporal diversity in habitat use is well documented for spawning Pacific salmon (Greene et al. 2010, Schindler et al. 2010). However, spatial and temporal habitat use by juvenile salmon is also of concern because of the reliance of most species on freshwater rearing habitat prior to marine residency, as well as the importance of freshwater growth to marine survival and reproductive success (Holtby et al. 1990, Quinn 2005). Furthermore, spatial and temporal variability in timing 
of movement and fish size traits supports life history diversity in Pacific salmon (Waples 1991). Understanding drivers of life history diversity can also improve fishery management: conserving habitats that support diverse phenotypic expressions can increase the ability of a population to persist, a concept known as phenotypic management (Watters et al. 2003).

Coho salmon (Oncorhynchus kisutch) in particular rely heavily on freshwater habitat because of their one to two-year residency prior to ocean migration (Shapovalov and Taft 1954, Sandercock 1991). This extended freshwater residency can increase the vulnerability of this species to freshwater habitat loss and degradation, which is evident in the federal Endangered Species Act listing of the four southern evolutionary significant units (ESU) (Brown et al. 1994, National Research Council 1996, Gustafson et al. 2007). It is well understood that, following emergence, juvenile fish (parr) rely upon cold-water, pool habitat to survive through the dry, summer seasons (Sandercock 1991, Nickelson et al. 1992, Reeves et al. 2011). However, winter-rearing strategies are more complicated. Rain events reconnect previously isolated or dry ephemeral streams and lateral floodplain zones, increasing habitat availability, growth, and survival benefits from different habitat types. This is evident in the winter movement of juvenile coho salmon to estuaries, floodplains, and non-natal streams during the winter season (Ebersole et al. 2006, Koski 2009, Bennett et al. 2014). The reasons for these movements may be the increased potential for growth and survival associated with these low velocity, high productivity habitats (Tschaplinski and Hartman 1983, Ebersole et al. 2006, Reeves et al. 2011) or predator avoidance (Dionne and Dodson 2002). 
The mechanisms that govern where and when juvenile coho movements occur are still unclear. Multiple studies have shown that timing of winter and spring movements correlate with fish size prior to the winter, with smaller fish more likely to migrate out of freshwater rearing habitat during the winter and larger fish more likely to wait until the spring to move downstream as smolts (Roni et al. 2012, Rebenack et al. 2015). This may be partly explained by competitive ability: larger individuals can outcompete smaller fish for limited rearing and foraging habitat, decreasing growth potential of smaller fish (Tschaplinski and Hartman 1983, Sandercock 1991, Nielsen 1992).

Rearing habitat may influence both fish size and timing of movement. Multiple studies have observed relatively greater survival and growth of juvenile coho salmon in rearing habitats that provide lower velocity flow, greater productivity, and complex shelter in the form of vegetation, large wood, and undercut banks (Peterson 1982, Tschaplinski and Hartman 1983, Fausch 1984). Moreover, coho salmon preferentially select these habitat types when available during the winter, including upstream migration to small tributaries, side channels, ponds, and alcove habitats (Ebersole et al. 2006, Bennett et al. 2011).

It is well documented that juvenile coho salmon in wild, northern populations exhibit multiple movement strategies within a population prior to smolt outmigration, and that fish size and winter habitat availability may influence timing of movement. However, there is limited research in the southern extent of the coho salmon range where populations are already diminished and supported by hatchery-rearing programs. Southern coho salmon populations may display different movement strategies: estuary 
rearing likely offers different growth potential because of seasonal estuary closures (lagoons) (Emmett et al. 2000, Hayes et al. 2008), while stream temperatures are typically warmer, potentially leading to faster growth and earlier maturation and migration in comparison to northern populations (Morita and Nagasawa 2010, Beacham et al. 2014). Stream productivity is likely more limited as well, since salmon spawner biomass is typically lower in southern latitudes where population abundances are reduced below historical numbers, reducing marine nutrient loading and egg consumption opportunities for growing juvenile fish (Naiman et al. 2002, Hicks et al. 2005, Bentley et al. 2015). Additionally, hatchery-reared populations may exhibit less size variability than wild fish, since spawning location and limited summer habitat can strongly influence prewinter juvenile distribution and size (Ebersole et al. 2009a, Flitcroft et al. 2014). Studies on other Pacific salmon species have also noted variability in timing of outmigration corresponding to variability in stream flow regimes (Zimmerman et al. 2015) and fish size at timing of outmigration associated with latitude (Freshwater et al. 2016). Thus, a better understanding of juvenile coho populations across their entire range is warranted.

In this study I attempt to identify juvenile coho salmon winter-rearing strategies in a southern, endangered hatchery-stocked population, as well as determine the importance of environmental conditions and fish size to coho salmon growth and movement timing through the winter and spring seasons, prior to smolt outmigration. To address this gap in our knowledge, a broodstock-reared population was studied in the Russian River, California, the largest remaining watershed in the southern regional Central California Coast Coho Evolutionary Significant Unit (ESU). Understanding the mechanisms 
influencing growth rates and movement in hatchery populations and human-impacted watersheds could help prioritize habitat restoration efforts aimed at salmon population recovery.

Climate change in western North America is expected to increase temperatures and alter stream flow regimes (Stewart et al. 2004). Specific to California, temperatures and precipitation intensity are predicted to increase, leading to more flood and drought occurrences (Pierce et al. 2013a, 2013b). My study took place during a severe drought, and habitat quality and connectivity may have been reduced in comparison to average rainfall years. This could limit coho salmon movement strategies by reducing habitat connectivity, providing a model of fish responses to future conditions. It is important to understand behavior of coho salmon already experiencing these conditions in order to apply this knowledge to more northerly, intact populations as well as future recovery and restoration management decision making.

To address these questions, movement data for a hatchery-reared coho salmon population in the Russian River watershed were analyzed for the 2014-2015 winter through spring season, covering potential early winter emigration and spring smolt outmigration from the stocking streams. Two main questions were addressed: 1) Are multiple movement seasons evident for coho salmon parr and smolts in a southern, endangered population; and 2) Are individual movement patterns related to fish size metrics, in-stream habitat quality, and landscape characteristics? Previous work has documented early winter pre-smolt movement when off-channel habitat and in-stream habitat quality are low, likely due to limited rearing and growth opportunities 
(Tschaplinski and Hartman 1983, Bennett et al. 2011). Later spring emigration timing has also been associated with higher quality rearing habitat, or greater growth potential (Quinn and Peterson 1996, Bennett et al. 2011). Watershed characteristics can influence in-stream habitat quality as well, with low-gradient, forested and wetland systems more likely to support salmon-rearing habitat (Sharma and Hilborn 2001, Ward et al. 2012). Therefore, I hypothesize that low quality streams (e.g., high gradient, limited vegetation, low productivity with limited prey abundance, and low in-stream habitat variability) and limited rearing habitat will reduce fish rearing and growth opportunities, and lead to earlier, pre-smolt winter movement and lower growth of smolt emigrants. I predict that streams with high quality and abundant rearing habitat (e.g., low gradient, high vegetation coverage, productive, and high in-stream habitat variability) will lead to more growth opportunities across the stream length, supporting later, spring smolt movement patterns and greater growth of smolt emigrants. Incorporating variables that represent fish competitive ability and habitat quality may help address our limited understanding of the interactive effects of habitat quality, location within a watershed, and fish size on spatial and temporal distribution of juvenile coho salmon.

\section{Methods}

Study Area

The Russian River watershed $\left(3850 \mathrm{~km}^{2}\right)$, located in Mendocino and Sonoma Counties in Northern California, drains into the Pacific Ocean (Figure 2.1) (mouth of Russian River at $38^{\circ} 27^{\prime} 2^{\prime \prime} \mathrm{N}$ and $123^{\circ} 7^{\prime} 46^{\prime \prime} \mathrm{W}$ ). The watershed has a Mediterranean 
climate, with the majority of precipitation occurring as rainfall during the winter season, primarily from October through March. Winter stream flows increase during initial precipitation events, and summer flows are maintained from groundwater sources and dam releases on the two main rivers, the Russian River and Dry Creek (Steiner Environmental Consulting 1996, National Marine Fisheries Service 2008). Coho salmon habitat is limited primarily to lower watershed, small, tributary streams due to the dominance of warm-water predator species and increased summer flows in the main stem, riverine habitats (Steiner Environmental Consulting 1996, National Marine Fisheries Service 2008). The watershed includes agriculture, a history of timber harvest, rural, and urban development land uses, as well as a variety of remaining natural ecosystems, including coastal redwood forests, oak woodlands, and seasonal marshes (Steiner Environmental Consulting 1996, Opperman et al. 2005).

\section{Coho Salmon}

The Russian River Coho Salmon Captive Broodstock Program (RRCSCBP) has raised and released juvenile coho salmon across the lower watershed since 2004, with the goal of increasing population numbers and spatial dispersion for this federally endangered species (FISHPRO 2004, National Marine Fisheries Service 2012). All biological data were collected under Section 10(a)(1)(A) Endangered Species Act permit 10094 and California Department of Fish and Wildlife, Scientific Collecting Permit 2043. Four streams that are part of this program are monitored using Passive Integrated Transponder (PIT) tags (Biomark, Boise, Idaho, FDX HPT12, 12.5-mm long) and 
stationary antenna systems: Dutch Bill Creek (DUT), Green Valley Creek (GRE), Mill Creek (MIL), and Willow Creek (WIL) (Figure 2.1). Hatchery-reared juvenile coho salmon were released into streams in June 2014 (WIL) and December 2014 (DUT, GRE, MIL). Prior to release, $\sim 15 \%$ of each stream release group were randomly selected, anesthetized with Tricaine Methanesulfonate (MS-222), PIT-tagged, weighed (g), and measured for length $(\mathrm{mm})$ at the hatchery. PIT-tagged individuals were reared in common tanks at the hatchery and are presumed to have similar growth and survival rates compared to all untagged fish in their respective release groups. Additionally, fish were monitored for tag loss prior to release and genetic diversity was maximized across streams by integrating multiple genetic lineages per release group (Mariska Obedzinski, personal communication). PIT technology is regularly used in studies of fish ecology because of the accurate information it can provide on individual growth, survival, and movement in small streams (Zydlewski et al. 2001, Gibbons and Andrews 2004, Achord et al. 2011).

Fish size was compared among study stream release groups to determine the degree of similarity (Table 2.1). Prior to comparisons, two fish were removed because they represented large outliers, based on their relative length and weight. All data were $\log _{10}$-transformed to improve distribution, although heteroscedasticity was a problem for all variables when data were assessed using Bartlett's test for equal variance. To address heteroscedasticity, the non-parametric Welch's $F$-test was used to compare multiple study stream release group fish sizes, followed by a Games-Howell post-hoc test, which addresses multiple pairwise comparisons when sample sizes and variances are unequal 
(Zimmerman and Zumbo 1993). Fish size variables included pre-winter absolute fish length (fork length, FL), relative fork length (individual fork length in comparison to mean fork length per release group), and Condition factor (K), which was calculated as (pre-winter wet weight * 100) / (pre-winter absolute fork length) (Weatherley and Rogers 1978). Pre-winter absolute fork length and pre-winter Condition were significantly different among all study stream release groups, likely due to the earlier release of WIL fish (FL: $F_{3,4034}=3222.00, p<0.001 ; \mathrm{K}: F_{3,4306}=32.73, p<0.001$ ). To address differences in absolute fork lengths, relative fork lengths were used to standardize fish size across the study streams for analyses (i.e., pre-winter relative fork length: $F_{3,4057}=0.00, p=1.00$ ). This suggests that relative distribution of fork lengths is comparable among the streams. Therefore, relative fork length was used in analysis rather than pre-winter absolute fork length, although absolute values were used to calculate individual growth rates. Despite observing significantly different Condition factor among the four study streams, this variable was still used as a predictor variable because of its potential importance in explaining fitness, growth, and behavior (Bentley and Schindler 2013, Sloat et al. 2014). PIT-tagged coho salmon movement patterns were monitored using stationary PIT antenna arrays that collected data continuously throughout the study period, although detections were limited periodically due to equipment malfunctions (Appendix A). All antenna sites consisted of paired antennas that covered a stream cross-section in a high velocity, shallow riffle habitat, with the exception of the GRE upstream site which was a single antenna (Figure 2.2). Riffle habitats were selected to increase detection efficiency due to shallower water depths and to detect coho salmon moving through a habitat rather 
than remaining fairly stationary for extended periods, which typically occurs in slower flowing pool habitats (Mariska Obedzinski, personal communication).

Fish movement was analyzed based on individual movement day past each antenna site. Three of the four study streams included two antenna sites, so movement was recorded for an individual at both an upstream site and a downstream site (GRE, MIL, and WIL), but at DUT movement was recorded at only the downstream site (Figure 2.2). Timing of movement was calculated as movement day for each individual fish past an antenna site, beginning at day one for all upstream detection sites and a separate day one for all downstream detections. Day one movement is therefore standardized across all streams and represents the first day a fish was detected at any site after all fish were stocked (10 December 2014 for all upstream and downstream sites). Some fish moved prior to all fish being stocked in the study streams; these fish were removed from analyses. Multiple fish could have a movement day value of one, but not all streams necessarily have fish that moved this first day. Movement is also assumed to be downstream, based on comparisons among upstream and downstream detection site timing when both sites were available per stream. Data on timing of movement had unequal variance and sample sizes among study streams. This led to the use of the nonparametric Welch's F-test and the post-hoc Games-Howell test, which are both robust to unequal variances and sample sizes, although less-so for non-normal distributions (Zimmerman 2012).

Three of the four study streams had fish detected that were released in other stream basins in the watershed. These fish were not included in the analysis of timing of 
movement due to the limited sample size for this inter-stream movement group. Instead, timing of movement and fish size for these individuals were compared as a group (interstream movement) in comparison to all other study fish (intra-stream movement).

Because no release stream PIT-tag detection days were available for the inter-stream fish, the earliest detection date was used to calculate movement day for these fish, since this would be the closest detection to when they began their winter movement (i.e., closest date to when they left the stream in which they were stocked). This is not the case for the inter-stream movement data, however, because this day is the first day they were detected moving upstream into a study stream.

All four study streams had downstream migrant smolt traps to capture fish during their spring outmigration. Downstream migrant smolt traps were installed in lower stream habitat in each of the four streams once winter flows subsided enough for safe trapping conditions and until stream flows were too low to capture fish or no more fish were trapped per stream (March - June 2015). All traps were located in close proximity to the downstream detection site in each study stream, except in the case of WIL, which had a trap located at the upstream detection site. Traps were checked at least daily, and all coho salmon were measured prior to release downstream. Following removal from the trap, all coho salmon were relocated to buckets with stream water and aerators to supply oxygen. All coho salmon $\geq 55 \mathrm{~mm}$ in length were anesthetized with MS-222, scanned for PIT tags (Avid, Norco, California, Power Tracker V), weighed, measured for absolute fork length, and then allowed to recover in another aerated bucket prior to release. Daily growth rates were calculated as the change in individual fork length between hatchery release and 
smolt trap recapture divided by the number of days between release and recapture. Individual relative spring fork lengths were also calculated, based on the mean fork length at recapture for each study stream. Overwinter growth rates were calculated for individuals released in December 2014, but growth rates for WIL fish encompassed both the summer and winter seasons due to their June 2014 release.

\section{Food Availability and In-Stream Habitat}

Food availability and in-stream habitat complexity and diversity can influence fish growth and movement patterns prior to smoltification (Quinn and Peterson 1996, Rosenfeld et al. 2005). To incorporate these potential factors I estimated macroinvertebrate abundance and in-stream habitat metrics for each study stream. Sampling was conducted in March 2015 following winter flow peaks, to represent springtime productivity and growth potential peaks for invertebrates as well as physical habitat diversity and quality at the midpoint during the movement study season and the beginning of the spring recapture measurement season (i.e., end point of growth rate estimate). Four in-stream sampling sites were selected along a longitudinal gradient within each of the study streams (Figure 2.2). Sites were randomly generated within four equal length stream segments of the main channel habitat for each study stream. Some sites were adjusted due to lack of access to stream sections, but all reaches were at least $1.4 \mathrm{~km}$ apart to minimize spatial autocorrelation. In the three streams with multiple PIT antenna arrays, sites were dispersed so that they were located both downstream and upstream of PIT detection arrays. 
Riffle habitats are often important prey feeding sources for juvenile salmonids because they provide drift supply to downstream pools where fish often feed (Rosenfeld and Raeburn 2009). To represent these supply habitats to pool-rearing fish, three riffle or glide habitat units separated by pool habitat were selected within each sampling site in March 2015, based on standard stream habitat type classifications (Bisson et al. 1982). Within each site, sampled habitat units were separated by at least one slow-flowing unit and their spatial location was recorded with a Garmin eTrex 20 GPS unit at the downstream end.

Habitat units were sampled for benthic macroinvertebrates across multiple microhabitat patches to represent variation in substrate, flow, and depth variability (Figure 2.2). A single cross-section within each habitat unit was sampled at three points, representing both slower flowing, wetted edges of the unit and the fast flowing thalweg to capture potential within patch differences in stream velocity, which can impact physical and community stream characteristics (Frissell et al. 1986). When the thalweg was located at a habitat edge, the center was sampled in addition to the edges. Sampling was performed using standard kick net and laboratory procedures for benthic invertebrate stream sampling (Carter and Resh 2001). A D-frame kick net with a 500- $\mu \mathrm{m}$ net was held downstream from the sampled substrate for 60 seconds while the sampler gently disturbed the substrate from the surface to a depth of $\sim 10$-cm by cleaning all substrate and vegetation within the approximate square area of the D-frame kick-net. The kick-net was rinsed into a $500-\mu \mathrm{m}$ sieve and large debris was cleaned and removed. The three kick net samples were composited into a single sample per habitat unit and preserved at a final 
concentration of $70 \%$ ethanol, except for the WIL sample sites, which were stored in $70 \%$ isopropyl alcohol and transferred to $70 \%$ ethanol within 90 days.

Preserved macroinvertebrate samples were sorted under a minimum of 10x magnification in the lab using a two-phase sampling method, in which large, rare species were removed first from a sample and then the remaining sample was subsampled until a minimum of 300 individuals were selected. This subsampling technique reduces variability in species richness, while maximizing sampling efficiency with dense samples (Vinson and Hawkins 1996). Subsampling was performed using a Caton subsampler, in which grids were randomly selected and individuals were enumerated until the minimum number of individuals were selected and entire grid cells were sorted. Abundance was estimated for the entire sample when a subset of all grid cells were sampled.

Average wetted and bankfull width was calculated for each unit based on current, wetted conditions and bankfull channel characteristics, including observed changes in slope, sediment, and vegetation structure. Habitat shelter quality was calculated as well based on California Department of Fish and Wildlife habitat metrics designed for salmonid monitoring, including habitat quality rankings and percent coverage of refuge (Flosi et al. 2010) (Appendix B). Variables utilized in analysis included mean shelter, as well as coefficients of variation of shelter and channel widths, which represent the degree of habitat heterogeneity across the study streams (Appendix B). 


\section{Landscape Influences}

Riparian and basin land use variables were calculated and extracted using geographic information systems (ArcGIS 10.2) and Geospatial Modeling Environment software (Beyer 2012, ESRI 2013) (Appendix B). National Elevation Data at the 10-m scale was used to calculate streamlines, watershed boundaries, and slope (U.S. Geological Survey 2000). Basins were delineated based on the mouth of each study stream (basin mouth), which was further separated into the downstream basins (i.e., upslope of each downstream antenna detection site), and upstream basins (i.e., upslope of each upstream antenna detection site). Land cover data were obtained from the 30-m scale National Land Cover Database (U.S. Geological Survey 2014) and were used to calculate percent coverage of vegetation and development activities. To examine basin and riparian influences on fish behavior, environmental data were extracted at multiple spatial scales: basin-scale (basin mouth, downstream, or upstream), 120-m riparian stream buffer, 60-m riparian stream buffer, and 30-m riparian stream buffer, as well as stream-scale slope, which represents the near-stream topology since data were extracted from the 10-m scale DEM derived streamline. To address the influence of travel distance through streams and to the ocean, stream distances ('as the fish swims') were calculated from each detection site as well as the basin stream mouths. Drainage density was calculated as well, which can represent the degree of habitat heterogeneity in basin, due to larger drainage density value associations with greater confluence density and slope gradients through a basin (Benda et al. 2004). 
Basin-scale Topographic Wetness Index (TWI) and Slope Position Classification (SPC) were also calculated based on relative slope positions per upstream and downstream basin (Beven and Kirkby 1979, Weiss 2001) (Appendix B). Topographic Wetness Index indicates the soil moisture content based on the potential for water pooling or flowing downslope, which can represent the degree of stream channel flooding (Beven and Kirkby 1979). The range of values calculated were scaled to an index ranging from 1 (low soil moisture and high water run-off potential) to 10 (high soil moisture and water pooling potential). Slope Position Classification was calculated using a 250-m and 500-m circular neighborhood around each 10-m elevation pixel, classifying basin areas into ridge, upper slope, middle slope, flat slope, lower slope, and valley types (Jenness 2006). Slope Position Classifications represent valley and stream channel characteristics, with constrained stream sections less likely to provide slow velocity, pool habitat than wider valley, low-gradient stream segments (Montgomery and Buffington 1997, Weiss 2001). Classifications were then compared to measured bankfull measurements conducted during in-stream data collection to determine accuracy of classifications.

Precipitation and temperature may catalyze initial winter movement of juvenile coho salmon (Hartman et al. 1982) and temperature is an important control of metabolic rates and growth (Sloat et al. 2014). To address these climate cues, air temperature and precipitation data were downloaded from the Parameter-Elevation Regressions on Independent Slope Model (PRISM) Climate Group (PRISM Climate Group 2004). Daily and two-week averages of total precipitation and mean temperature data were extracted for each PIT detection site for the entire movement study period, including the month 
prior to fish movement (November 2014 - June 2015). Previous studies have observed correlations between fish movement and daily streamflow patterns and seasonal temperature variation (Bustard and Narver 1975, Tschaplinski and Hartman 1983). Twoweek averages of precipitation and temperature data were highly correlated with daily values, so only daily values were used in analyses. Precipitation data were used in place of stream flow data, and when combined with other flow-related variables, such as upslope characteristics, drainage density, and vegetation, can provide an effective understanding of in-stream flow conditions (Poff and Zimmerman 2010, Price 2011). Daily precipitation and temperature values were then joined to each fish movement date, to compare individual movement patterns to local climatic conditions.

\section{Statistical Analysis}

All analyses were conducted using R version 3.2.2 (R Core Team 2015) with the MASS and RandomForest packages. Due to the high number of landscape and in-stream variables, principal component analysis (PCA) was used to reduce watershed data dimensionality based on relative importance as well as similarity among variables. Variables were identified by type (geomorphology, in-stream habitat, vegetation, and agriculture and development) and summarized as means and standard deviations or coefficients of variation to quantify average conditions and variability among basins (basin summaries available in Appendix B). Basin scales (basin mouth, downstream basin, upstream basin) and riparian scales (120-m, 60-m, 30-m, and near-stream scales) were analyzed simultaneously to explore differences among basin types. Relative 
importance of variables were similar in PCA analyses that included both basin and riparian-scale values compared to analyses including just basin-scale values (Appendix C). Therefore, basin-scale data were used in all further analyses. To incorporate variation in watershed-scale conditions in further analyses, I extracted the site scores along principal component (PC) 1 and 2 for each stream basin, which were used in modeling fish movement and growth (below). The small number of study streams precluded the direct use of landscape variables in fish movement and growth models.

Fish size analyses were conducted for the subset of individuals detected within each study stream release group. These additional tests were used to determine if fish size patterns were similar to release group comparisons prior to winter movement. As with the release group comparisons, pre-winter absolute fork length, relative length, Condition factor, and growth rates were compared among streams using Welch's $F$-test and the post-hoc Games-Howell test. When variables met assumptions of normality and equal variance, parametric ANOVA or $t$-tests were used.

The power of landscape, climate, and fish size variables to predict timing of movement and individual growth rates were analyzed using random forest models. Random forest modeling is well suited to large, non-parametric data sets that include both categorical and numerical variables that may be highly correlated, which was the case with this data set (Breiman 2001, Cutler et al. 2007). Model explanatory power is determined by averaging many regression tree outputs into a single forest. Each tree is built by randomly selecting two-thirds of the data set to assess predictive power of each variable to the response (out of bag error) while the remaining one-third of data is used to 
assess the accuracy of this tree in predicting the response (Breiman 2001). Because accuracy and predictive relationships are relative to the variables included in the model, random forests determine the relative importance of variables in reducing overall model predictive error, rather than the significance of individual variables. Model explanatory success is based on the Pseudo $R^{2}$, which was calculated as 1 - the mean square error across all trees in the model divided by the variance in the response. Predictor variable importance is based on the mean percent decrease in overall model accuracy in predicting the response with the removal of that single predictor, which was calculated based on the out-of-bag error rate. Variable importance scores were then standardized (variable importance/standard deviation) to determine relative importance among the predictor variables. Relationships between individual predictor variables and the response were also visualized using partial dependence plots, which depict the impact of one predictor on the response if all other predictors are held constant. Only non-watershed variables were visualized with partial dependence plots (temperature, precipitation, movement, fish size) since limited replication of study streams did not allow for one-on-one visualization of PC components with fish movement and growth.

Because detection rates (and potentially survival) differed among upstream and downstream detection sites as well as at spring smolt traps, random forest models had different sample sizes. However, the same fish could be represented in multiple models if detected at upstream and downstream detection sites and at spring smolt traps. Although random forest models allow for multi-collinearity, correlation among variables was assessed using Pearson's correlation. All models included correlations $<0.66$ except for 
the downstream detection site model, which included highly correlated $(>0.99)$ principal coordinates among the basins. These correlated variables were left in the model to determine the relative importance of different catchments on fish behavior. Random forest models included $\log _{10}$-transformed fish size variables for consistency with other analyses. All models had 3000 trees, which stabilized tree error.

\section{Results}

Movement patterns were documented using PIT detection site data in the four study streams from December 10, 2014 through the end of smolt migration for the year (June 18, 2014). A total of 1779 individual juvenile coho salmon were detected moving through the four study streams, of which 1291 individuals were detected moving past one of the three upstream detection sites, 1246 were detected moving past one of the four downstream detection sites, and 758 individuals were detected at both upstream and downstream sites per stream (Table 2.3). Similar to release group comparisons, detected individuals pre-winter absolute fork length $\left(F_{3,499}=448.12, p<0.001\right)$ and Condition factor $\left(F_{3,422}=3.94, p=0.009\right)$ differed significantly among study streams (Figure 2.3a, b). Pre-winter relative fork lengths were also differed significantly, with WIL having a lower relative fork length for detected individuals $\left(F_{3,498}=4.27, p=0.005\right)$; however, the median values were much more similar for relative fork lengths compared to absolute fork lengths (Figure 2.3c).

Observed movement patterns across the watershed exhibited a generally bimodal distribution, with fish movement past both upstream and downstream detection sites 
occurring during the winter (December 2014 - February 2015) or the spring (March 2015 - June 2015) (Figure 2.4). Movement timing among streams also differed significantly for both upstream $\left(F_{2,332}=8.66, p<0.001\right)$ and downstream sites $\left(F_{3,244}=356.86, p<\right.$ 0.001) (Figure 2.5). Some inter-stream movement was documented, with fish stocked in other watershed streams observed in DUT (32 fish, which originated from three other streams), GRE (2 fish, originated from two other streams), and MIL (8 fish, originated from four other streams). All inter-stream detections occurred at downstream detection sites, and no inter-stream movement was documented for WIL. Significant differences were observed for movement timing between inter-stream and intra-stream fish groups $\left(F_{1,51}=315.91, p<0.001\right)$, with inter-stream fish moving significantly earlier during the study period (Figure 2.6). No significant difference existed in pre-winter relative fork lengths between fish making inter-stream and intra-stream movements $\left(F_{1,1823}=0.03, p\right.$ $=0.865)$.

A subset of 219 individuals were recaptured in spring to calculate spring recapture absolute fork lengths, spring relative fork lengths, and growth rates over in the four streams from March 11 to June 11, 2015 (Table 2.4). Similar to release groups, prewinter absolute fork length of this subset was differed significantly among study streams $\left(F_{3,105}=201.31, p<0.001\right)$. Spring recapture absolute lengths were significantly different among streams $\left(F_{3,274}=48.15, p<0.001\right)$ except for DUT and MIL (Figure 2.7a); however no significant differences in spring relative fork length distributions of these fish were found among the streams $\left(F_{3,274}=0.59, p=0.620\right)$ (Figure 2.7b). Growth rates differed significantly among study streams $\left(F_{3,105}=3.40, p=0.021\right)$ (Figure $2.7 \mathrm{c}$ ), where 
MIL fish had a significantly greater growth rate than DUT fish (Games-Howell post-hoc test $p=0.019$ ); no differences existed among all other stream pairwise comparisons (Figure 2.7c).

To understand potential differences in landscape and in-stream habitat characteristics among study stream basins, principal components analysis (PCA) was used to assess dissimilarities among basin types, study streams, and the importance of variables in explaining these differences. The first two axes of the PCA explained $77.5 \%$ of the total variation across the study basins, with PC 1 explaining $58.5 \%$ of the total variance and PC 2 explaining 19.0\% of the total variance (Figure 2.8, Appendix C). PC I was primarily explained by coniferous forest coverage, basin-scale geomorphology (slope characteristics), development, agriculture, herbaceous vegetation, and invertebrate abundance (Appendix C). PC II was primarily explained by wetland coverage, drainage density, in-stream physical habitat parameters, and deciduous and mixed forest coverage (Appendix C).

Study streams were closely clustered among basin types, although PC I was primarily positively related to the GRE study basins while PC II was positively associated with MIL and negatively associated with DUT and WIL (Figure 2.8). The GRE basin was positively associated with development and agricultural land cover, nonforested vegetation, invertebrate abundance, and low gradient habitat and high surface water pooling potential (high TWI) values while negatively associated with high slope and coniferous forest coverage. The downstream basin type for GRE was more strongly positively influenced by low gradient and development characteristics than the upstream 
basin. The MIL basin was positively associated with non-coniferous forest coverage and in-stream physical habitat variation, as well as negatively associated drainage density and wetland coverage. The DUT basin was primarily associated with high gradient variables, although both DUT basin types were closely grouped at the center of the PCA model. The WIL basin was positively associated with drainage density and wetland coverage, especially the downstream basin type. The WIL basin was also negatively associated with in-stream physical habitat variation and deciduous and mixed forest coverage.

Relationships among fish movement and growth response variables and watershed, climate, and fish size predictors were modeled to understand potential interactions and directional relationships (Table 2.5). Eighty percent of total variation in movement past the upstream detection sites were captured by the random forest model, with precipitation, temperature, and watershed conditions providing explanatory power ( $\mathrm{n}$ $=1291$, mean square residuals $=538.3)($ Figure 2.9, Appendix D). Daily temperature and precipitation, and stream basin PC 2 and PC 1 explained the majority of the variation, followed by fish size metrics (Figure 2.9, Appendix D). Earlier fish movement occurred during cooler winter temperatures and greater precipitation events while fish size had a limited influence on upstream movement (Figure 2.10). The importance of PC 1 and PC 2 may explain the significantly earlier movement time of fish past the upstream detection sites in GRE and MIL in comparison to WIL (Figure 2.5a). The downstream and entire GRE basins were positively associated with PC 1 , which was characterized by greater development, agriculture, higher invertebrate productivity, and lower slope gradient. Earlier movement from GRE may be related to high productivity and availability of low 
gradient habitat downstream in comparison to upstream habitats. Earlier movement from MIL may be because of similar patterns: the upstream MIL basin was positively associated with PC 2, which was characterized by in-stream habitat variability and deciduous forest coverage, which are not indicative of preferred off-channel winter rearing habitat features. The upstream WIL basin was more closely clustered with stream flow dissipation and off-channel rearing features, such as wetlands and high drainage density, potentially reducing the impact of high-velocity flows from precipitation events on fish movement in this stream (Figure 2.8).

Movement past the downstream detection sites were affected by movement past the upstream sites and downstream daily temperature and precipitation, followed by upstream daily temperature, PC 2 and PC 1 metrics for all basins, with $73.9 \%$ of total movement day variance explained $(\mathrm{n}=758$, mean square residuals $=128.0)($ Figure 2.11, Appendix D). Fish that moved earlier past upstream detection sites were more likely to move earlier past downstream sites as well (Figure 2.12). Temperature and precipitation had limited effect on movement timing in comparison to the upstream movement model (Figure 2.12). The importance of PC 2 and PC 1 may again explain later movement past the downstream detection sites in GRE and WIL and the earlier movement of fish out of DUT and MIL basins (Figure 2.5b). GRE was associated with high productivity and low gradients in its lower basin, potentially supporting more growth and foraging benefits and later movement from this stream basin (Figure 2.8). WIL was also associated with beneficial winter rearing habitat, with drainage density and wetland coverage describing this basin on the PC 2 axis (Figure 2.8). DUT and MIL may have earlier fish movement 
patterns because of the association of lower MIL with forest coverage and in-stream physical habitat heterogeneity, which are not likely supporting features of floodplain rearing. DUT had the earliest movement timing of the streams, which may be because of the clustering of this basin along gradient features in the PCA analysis (Figure 2.8).

Condition factor was removed from this model because it had a negative variable importance score, and reduced model accuracy when included.

Growth rate models captured $70.8 \%$ of total variation in the data set, with fish size metrics influencing growth more so than basin characteristics $(n=219$, mean square residuals $\left.=6.78 \times 10^{-8}\right)$. Pre-winter relative fork length was the most important predictor of growth, followed by spring relative fork length, downstream movement day, and PC 2 and 1 from the downstream basins (Figure 2.13, Appendix D). Pre-winter relative fork length and downstream movement day were inversely related to growth, meaning larger fish and fish that moved later in the season grew more slowly (Figure 2.14). However, fish that had a higher relative length in the spring grew more quickly, suggesting that prewinter fish size may not determine smolt size alone (Figure 2.14).

\section{Discussion}

Due to diminished population abundances, hatchery stocking and stream restoration are common strategies utilized to support Pacific salmon recovery efforts (Fraser 2008, Roni et al. 2008, Araki and Schmid 2010, Ogston et al. 2015). One important aspect of recovery is conservation of life history diversity, including timing of movement of juvenile fish (Waples 1991). This study identified multiple movement 
strategies of juvenile coho salmon from four streams in the Russian River watershed, as well as the importance of temperature and precipitation patterns, landscape characteristics, and fish size in influencing growth and timing of movement.

\section{Movement}

Three winter-rearing strategies were observed through monitoring of PIT-tagged coho salmon in the Russian River watershed from December 2014 through June 2015: 1) winter movement after stocking from the hatchery; 2) rearing in streams until the spring season when smolt migration occurred; and 3) a small subset of inter-tributary movers, with fish stocked in non-study streams moving into and back out of three of the four study streams. Variation in movement was primarily explained by temperature and precipitation events, but watershed variables were the next most important (Figure 2.9 and Figure 2.11). Fish size was outweighed by these coarser-scale variables, with limited power in predicting movement past both upstream and downstream detection sites.

The importance of watershed variables may indicate landscape interactions with precipitation, temperature, and stream productivity. PC 2 was primarily described winter habitat quantity and quality characteristics, due to the association of wetland, drainage density, in-stream habitat variability, and deciduous forest variables (Figure 2.8). High drainage density is associated with greater habitat heterogeneity and valley floor area (Benda et al. 2004), features indicative of preferred juvenile coho salmon winter habitats, such as wetland and pool features (Reeves et al. 2011). PC 1 was primarily described stream productivity characteristics, with a positive association of development, 
agriculture, and invertebrate abundance, and negative association with coniferous forest (Figure 2.8). These variables may influence stream temperatures (limited winter canopy from low coniferous forest coverage) as well as nutrient levels from development and agriculture run-off, potentially increasing invertebrate abundances (reviewed in Allan 2004). Additionally, deciduous forests are linked to high terrestrial prey inputs in small streams (Baxter et al. 2005) as well as potential nutrient resources from nitrogen-fixing alder species (Bisson et al. 2009). Productivity and complex habitats may influence how coho salmon respond to winter disturbance events, such as floods. Warmer waters may increase growth opportunities due to positive associations between water temperatures and fish metabolic rates, further improving the quality of winter rearing habitats in these low canopy basins when high water velocities are not a limiting factor. These foraging and rearing benefits may delay timing of movement.

Juvenile coho winter movement tends to coincide with increased stream flows (Bramblett et al. 2002, Miller and Sadro 2003, Roni et al. 2012, Jones et al. 2014), decreasing water temperatures (Tschaplinski and Hartman 1983), and reduced habitat complexity (Tschaplinski and Hartman 1983, Roni et al. 2012). The importance of low temperatures and high precipitation intensity for early movement past upstream detection sites in my study follows these previously documented stream flow patterns, especially when channel complexity is considered (i.e., PC 2 watershed variables). For instance, precipitation may have less intense or delayed effects on stream flow conditions in systems with greater drainage densities, low-gradient habitats, and in the presence of channel roughness characteristics, such as forest land and varied in-stream channel 
widths, which are usually formed by large wood and boulder structures (Bisson et al. 1982). DUT and MIL both had significantly earlier movement past downstream detection sites in comparison to GRE and WIL. This may be due to the association of GRE and WIL with low gradient, wetlands, herbaceous vegetation, and high invertebrate abundances (Figure 2.8). MIL and DUT were more associated with high gradients throughout the basins, based on greater slopes and the presence of ridge lines ((Figure 2.8). Therefore, large rain events may cause greater velocity stream flows, due to lack of dissipation across wide and rough channels and floodplain features in these two streams (Montgomery 1999). These patterns all support my hypothesis of greater off-channel habitat quantity leading to delayed movements, leading to more spring smolt migrants than early winter movers.

The importance of in-stream habitat variability may influence fish movement and growth opportunities. Although fish left MIL on average earlier than GRE and WIL for downstream detection sites, MIL fish still left significantly later than DUT and at comparable times to fish from GRE for upstream detection sites (Figure 2.5). Habitat heterogeneity in MIL may provide more refuge and foraging opportunities for fish, delaying movements. In-stream habitat heterogeneity is linked to greater pool-riffle ratios, leading to more prey drift to downstream feeding salmon (Rosenfeld and Raeburn 2009) and pool habitat, an important feature when off-channel rearing is limited. These characteristics all support the original hypothesis of greater winter habitat quality leading to later movement for fish past both upstream and downstream detection sites. 
Fish that moved between streams (inter-stream) moved significantly earlier than fish that stayed in their stocked stream (intra-stream) in this study, which may be explained by winter habitat characteristics and interactions with climate conditions. On average, inter-stream fish moved 54 days earlier than intra-stream fish (Figure 2.6). Interstream fish may leave their stocking streams actively searching for better habitat during initial winter storm events, which primarily occurred in the first sixty days of the study, when larger rain events occurred and prior to the majority of spring fish movement (Figure 2.4). Over 95\% (42/43) of the individuals detected in the inter-stream movement group were stocked downstream of the study streams in which they were detected, suggesting active, upstream swimming during the winter season. Active swimming may mean that individuals preferentially sought habitats that improved their ability to compete and survive, such as foraging and rearing space. No significant differences were observed when fish size or precipitation on movement day were compared between inter- and intra-stream movers, suggesting other drivers may be important, such as differences in habitat between stocked-streams and streams to which fish moved. Five of the seven fish that moved into Mill Creek were stocked into Dry Creek that fall, a higher order stream that Mill Creek feeds into, with controlled dam-release flows. Fish may leave Dry Creek for Mill Creek because it is a smaller system, potentially providing more sheltered habitat from high velocity stream flows. These patterns support delayed movement associated with higher quality winter rearing habitat, but further work considering habitat differences between streams that fish leave and streams that fish move into may provide more context on fish-habitat relationships during the winter season. 
Pre-winter relative fork length and Condition factor were not important in predicting movement patterns. This contradicts previous studies, which found that smaller wild coho salmon were more likely to leave streams during the winter (Bennett et al. 2011, Roni et al. 2012). However, the relationship between pre-winter fish size and movement can also vary by year, suggesting that shifts in habitat conditions and growth potential are an important driver of when fish move out of freshwater habitat (Pess et al. 2011, Rebenack et al. 2015). When fish move to habitats that have greater growth potential than their previous habitat, fish size can also have limited predictive power of this behavior (Quinn and Peterson 1996, Jones et al. 2014). Variability in fish size in my study may also be low in comparison to analyses with wild fish since hatchery fish in three of the four study streams only experienced one season of environmental selection (winter). Wild coho must also survive in streams from the spring through fall seasons, and habitat unit, stream reach, and basin conditions can strongly influence fish size and survival to the onset of winter (Ebersole et al. 2009a). Fish in Willow Creek had a more narrow range and significantly smaller detected pre-winter relative fork lengths in this study (Figure 3c). This may be explained by summer habitat limitations, potentially reducing growth potential and thus the range of relative lengths in comparison to more recently hatchery-released fish in the three other streams. Greater variability in lengths may have been observed if all fish reared through the study streams in the summer across a gradient of habitat qualities, as observed in previous work (Ebersole et al. 2009a). Homogeneity in fish size may limit my ability to judge the importance of fish length and Condition on behavior, or the ability to capture its importance in this study. 
Later seasonal movement by fish (spring smolt movers) may be in response to different cues than early winter movers despite originating from the same hatchery release groups. Spring movement past upstream detection sites was associated with increased temperatures and periods of lower precipitation intensity, indicative of more stable stream flow and thermal conditions. Others have hypothesized that smolt movement may be strongly influenced by photoperiod and temperature cues rather than simply stream flow conditions (Quinn 2005, Roni et al. 2012). This may be the case for the hatchery-stocked fish in this study, since their peak spring movement timing is comparable to previous years in these streams (California Sea Grant, unpublished data). Temperature and precipitation may have been less important in predicting movement past downstream detection sites due to warmer than average drought conditions that prevailed over the period of my study or the importance of photoperiod over temperature and streamflow on catalyzing spring smolt movement. Reduced variation due to drought would limit the range of thermal conditions individuals experienced through the winter and spring seasons, potentially limiting its effect on spring smolt movement and movement past the lower watershed, downstream detection sites.

\section{Growth}

Understanding drivers of growth is essential if we are to improve freshwater survival of coho salmon (Ebersole et al. 2009b, Roni et al. 2012). Unlike timing of movement, growth appeared to be primarily influenced by fish size metrics, suggesting that the same abiotic and biotic drivers do not directly affect both movement and growth. 
Growth appeared to outweigh initial size at stocking in determining spring fork lengths: growth rates were greater for fish that were relatively larger than other spring movers when recaptured in the spring. Size-dependent mortality may influence this observed relationship: fish detected in spring were significantly larger at release (pre-winter measurements) compared to their original release group $\left(F_{1,2911}=38.50, p<0.001\right)$. This suggests that smaller fish were less likely to be detected or survive the winter. However, small fish size prior to the winter is not always associated with smaller smolt sizes, since winter rearing habitat that has high growth potential can outweigh pre-winter fish length (Quinn and Peterson 1996, Miller and Sadro 2003, Ebersole et al. 2009b). This could be the case in my study: greater growth potential for smaller fish that did survive to be detected may allow them to outpace fish that were initially larger, leading to relatively smaller stocked fish being relatively larger smolts in the spring. This suggests that habitat is more important than fish relative length beyond a certain minimum value prior to the winter season, in terms of predicting growth and relative size for spring smolts.

\section{Implications}

This study demonstrates the importance of understanding both watershed conditions and fish size for salmon recovery efforts involving broodstock programs. Further research that expands the spatial scale of hatchery-stocked streams to establish a larger environmental gradient could improve our understanding of fish-habitat relationships in hatchery-influenced systems. By occurring during an extreme drought, this study may represent future conditions in this watershed as well as ones that more 
northern populations may face. Rainfall and temperature patterns may become increasingly important in predicting when fish move and from where. Furthermore, coarse-scale patterns (watershed conditions) were more important than fish size in predicting timing of movement. Connectivity and habitat quality across streams and within streams is an essential consideration for determining the ability of fish to respond to winter stream environments.

Hatchery programs may be able to better mimic wild coho salmon population life histories by diversifying spatial and temporal stocking. Releasing fish into streams throughout the watershed and across different seasons prior to smolt outmigration could increase portfolio effects by increasing variability in movement through streams and potentially entry into the ocean as well (Doak et al. 1998, Tilman et al. 1998). For instance, the range of dates over which fished moved may be reduced if fish were only stocked in streams that supported early winter movement (e.g., Dutch Bill) or streams that supported later season movement (Willow, Green Valley). Supporting stream populations and the habitats that they rely on can diversify behavior across a watershed, and in turn increase population resiliency (Hilborn et al. 2003).

Watershed management must continue to focus on large-scale processes when considering conservation and recovery goals for highly mobile fish species (Fausch et al. 2002). After climate and movement variables, watershed variables linked to winter habitat quality and quantity were the most important in predicting movement past upstream and downstream detection sites. Maintaining these connections and diverse habitat features may allow for continued support of diverse life history strategies, even 
for endangered fish during drought years. Supporting diverse habitats and phenotypes allows phenotypic management to be incorporated into population recovery efforts, increasing the likelihood of population persistence despite unknown future environmental conditions (Watters et al. 2003). In the case of coho salmon, early winter movement strategies may allow individuals to increase their growth potential by moving to other stream habitats that provide additional rearing opportunities. This may allow fish that are smaller at the onset of winter to grow enough to outpace fish that were initially larger, potentially increasing survival probability of these larger smolts (Quinn and Peterson 1996, Ebersole et al. 2009b). The importance of these early movers is also evident at the spawning stage, with early juvenile movers supplementing returning spawning populations (Jones et al. 2014, Bennett et al. 2014). Recognizing these patterns and their drivers is the first step in phenotypic management, and should be continually studied when population resiliency is reduced or threatened, as in the case of many Pacific salmon populations. 


\section{Tables}

Table 2.1. Summary statistics for release groups per study stream, including mean and standard deviation of pre-winter fish size variables. All measurements were completed at the hatchery during the measurement date range. Release date is when fish were released into each study stream. $K=$ (pre-winter wet weight $(g) * 100) /$ (pre-winter absolute fork length $(\mathrm{mm})$ ) (Weatherley and Rogers 1978). MN = Mean, SD = Standard Deviation, $F L=$ fork length, $K=$ Condition factor, DUT $=$ Dutch Bill Creek, GRE = Green Valley Creek, MIL = Mill Creek, WIL = Willow Creek.

\begin{tabular}{|c|c|c|c|c|c|c|c|}
\hline $\begin{array}{l}\text { Study } \\
\text { Stream }\end{array}$ & $\begin{array}{l}\text { PIT-tagged } \\
\text { Fish } \\
\text { Released } \\
\text { (total } \\
\text { release size) }\end{array}$ & $\begin{array}{l}\text { Measurement } \\
\text { Date Range }\end{array}$ & $\begin{array}{l}\text { Release } \\
\text { Date }\end{array}$ & $\begin{array}{l}\text { MN } \\
\text { Release } \\
\text { FL +/- } \\
\text { SD } \\
(\mathbf{m m})\end{array}$ & $\begin{array}{l}\text { MN } \\
\text { Release } \\
\text { Relative } \\
\text { FL +/- } \\
\text { SD }\end{array}$ & $\begin{array}{l}\text { MN } \\
\text { Release } \\
\text { Weight } \\
\text { +/- SD } \\
\text { (g) }\end{array}$ & $\begin{array}{l}\text { MN } \\
\text { Release } \\
\text { K+/- } \\
\text { SD }\end{array}$ \\
\hline DUT & $\begin{array}{l}1821 \\
(12164)\end{array}$ & $\begin{array}{l}9 / 22 / 14- \\
9 / 24 / 14\end{array}$ & $12 / 4 / 14$ & $\begin{array}{l}82+/- \\
10\end{array}$ & $\begin{array}{l}0.0+/- \\
0.12\end{array}$ & $\begin{array}{l}6.9+/- \\
2.5\end{array}$ & $\begin{array}{l}0.0012 \\
+/-0.0\end{array}$ \\
\hline GRE & $\begin{array}{l}1514 \\
(10088)\end{array}$ & $\begin{array}{l}10 / 14 / 14- \\
10 / 15 / 14\end{array}$ & $12 / 9 / 14$ & $\begin{array}{l}85+/- \\
10\end{array}$ & $\begin{array}{l}0.0+/- \\
0.12\end{array}$ & $\begin{array}{l}7.6+/- \\
2.9\end{array}$ & $\begin{array}{l}0.0012 \\
+/-0.0\end{array}$ \\
\hline MIL & $\begin{array}{l}2718 \\
(18173)\end{array}$ & $\begin{array}{l}9 / 8 / 14- \\
9 / 15 / 14\end{array}$ & $\begin{array}{l}12 / 2 / 14- \\
12 / 3 / 14\end{array}$ & $\begin{array}{l}80+/- \\
10\end{array}$ & $\begin{array}{l}0.0+/- \\
0.12\end{array}$ & $\begin{array}{l}6.4+/- \\
2.5\end{array}$ & $\begin{array}{l}0.0012 \\
+/-0.0\end{array}$ \\
\hline WIL & $\begin{array}{l}2254 \\
(15393)\end{array}$ & $\begin{array}{l}5 / 23 / 14- \\
6 / 4 / 14\end{array}$ & $6 / 11 / 14$ & $66+/-5$ & $\begin{array}{l}0.0+/- \\
0.075\end{array}$ & $\begin{array}{l}3.4+/- \\
0.87\end{array}$ & $\begin{array}{l}0.0012 \\
+/-0.0\end{array}$ \\
\hline
\end{tabular}


Table 2.2. Summary statistics by landscape and in-stream variable type across all basin types $(n=11)$. Methods in Appendix B. SPC $=$ Slope Position Classification, TWI $=$ Topographic Wetness Index, SD = standard deviation, BMI = benthic macroinvertebrate abundance, $\mathrm{Dev} .=$ Development, $\mathrm{CV}=$ coefficient of variation.

\begin{tabular}{|c|c|c|c|}
\hline Variable & Minimum & Maximum & Median \\
\hline \multicolumn{4}{|l|}{ Basin Area and Distance } \\
\hline Basin Area $\left(\mathrm{km}^{2}\right)$ & 17.6 & 98.1 & 30.6 \\
\hline Stream Length $(\mathrm{km})$ & 25.6 & 136 & 41.9 \\
\hline Distance to ocean $(\mathrm{km})$ & 4.35 & 59.2 & 37.3 \\
\hline Distance to stream mouth $(\mathrm{km})$ & 0 & 9.98 & 0.680 \\
\hline \multicolumn{4}{|l|}{ Geomorphology } \\
\hline Drainage density & 0.0013 & 0.0015 & 0.0014 \\
\hline Relief ratio & 0.043 & 0.213 & 0.061 \\
\hline Mean \% Slope & 14.4 & 40.8 & 31.6 \\
\hline SPC Valley (\%) & 39.6 & 47.9 & 46.8 \\
\hline SPC Low Slope (\%) & 1.04 & 4.97 & 1.47 \\
\hline SPC Flat Slope (\%) & 0.010 & 6.14 & 0.270 \\
\hline SPC Middle Slope (\%) & 2.14 & 3.19 & 2.74 \\
\hline SPC Upper Slope (\%) & 1.03 & 3.91 & 1.42 \\
\hline SPC Ridge (\%) & 42.2 & 50.3 & 48.2 \\
\hline Mean TWI (\%) & 2.23 & 2.65 & 2.37 \\
\hline SD TWI $(\%)$ & 0.523 & 0.593 & 0.543 \\
\hline \multicolumn{4}{|l|}{ Vegetation } \\
\hline Mean Canopy Cover (\%) & 27.3 & 71.1 & 58.9 \\
\hline Barren Land (\%) & 0 & 0.124 & 0 \\
\hline Deciduous Forest (\%) & 0.464 & 3.70 & 1.65 \\
\hline Conifer Forest (\%) & 18.7 & 80.2 & 63.4 \\
\hline Herbaceous $(\%)$ & 3.10 & 39.4 & 15.3 \\
\hline Herbaceous Wetland (\%) & 0 & 0.289 & 0 \\
\hline Mixed Forest (\%) & 3.02 & 12.6 & 5.84 \\
\hline Shrub (\%) & 6.06 & 14.6 & 12.05 \\
\hline Wooded Wetland (\%) & 0 & 2.57 & 0.350 \\
\hline \multicolumn{4}{|l|}{ Development and Agriculture } \\
\hline Impervious (\%) & 0.034 & 2.12 & 0.119 \\
\hline Cultivated Crops (\%) & 0 & 5.07 & 0 \\
\hline Dev. High (\%) & 0 & 0.159 & 0 \\
\hline Dev. Low (\%) & 0 & 2.03 & 0.020 \\
\hline Dev. Medium (\%) & 0 & 0.853 & 0 \\
\hline Dev. Open $(\%)$ & 1.99 & 10.74 & 3.77 \\
\hline \multicolumn{4}{|l|}{ In-stream habitat } \\
\hline Mean BMI & 498 & 3717 & 834 \\
\hline SD BMI & 372 & 1892 & 607 \\
\hline CV Bankfull Width & 0.958 & 16.5 & 4.23 \\
\hline CV Shelter & 0.698 & 1.61 & 0.990 \\
\hline CV Wetted:Bankfull Width & 0.896 & 11.5 & 3.03 \\
\hline CV Wetted Width & 1.74 & 6.47 & 3.06 \\
\hline Mean Shelter & 6.50 & 51.7 & 21.6 \\
\hline
\end{tabular}


Table 2.3. Summary statistics for the subset of fish detected per release group, where fish size variables are from prewinter measurements. All detected individuals were measured at the hatchery prior to release into each study stream.

No upstream detections are recorded for DUT since only one PIT antenna site was present. $M N=M e a n, S D=S$ tandard Deviation, $\mathbf{F L}=$ fork length, $\mathrm{K}=$ Condition factor, Det. $=$ Detection, DUT $=$ Dutch Bill Creek, GRE $=$ Green Valley Creek, MIL = Mill Creek, WIL $=$ Willow Creek.

\begin{tabular}{|c|c|c|c|c|c|c|c|}
\hline $\begin{array}{l}\text { Study } \\
\text { Stream }\end{array}$ & $\begin{array}{l}\text { PIT-tagged } \\
\text { fish } \\
\text { detected }\end{array}$ & $\begin{array}{l}\text { Mean FL } \\
+/- \text { SD } \\
(\mathbf{m m})\end{array}$ & $\begin{array}{l}\text { MN Relative FL } \\
+/- \text { SD }\end{array}$ & $\begin{array}{l}\text { MN Weight } \\
\text { +/- SD (g) }\end{array}$ & MN K +/- SD & $\begin{array}{l}\text { Mean US Det. Day } \\
\text { +/- SD (n) }\end{array}$ & $\begin{array}{l}\text { Mean DS Det. Day } \\
+/- \text { SD (n) }\end{array}$ \\
\hline DUT & 284 & $83+/-10$ & $0.013+/-0.12$ & $7.2+/-2.7$ & $0.0012+/-0.0$ & -- & $53+/-52(284)$ \\
\hline GRE & 649 & $86+/-10$ & $0.014+/-0.12$ & $8.1+/-2.9$ & $0.0012+/-0.0$ & $122+/-60(630)$ & $152+/-16(295)$ \\
\hline MIL & 737 & $81+/-10$ & $0.0070+/-0.12$ & $6.6+/-2.5$ & $0.0012+/-0.0$ & $124+/-43(559)$ & $123+/-44(618)$ \\
\hline WIL & 109 & $65+/-4$ & $-0.013+/-0.065$ & $3.2+/-0.8$ & $0.0012+/-0.0$ & $138+/-33(102)$ & $151+/-14(49)$ \\
\hline
\end{tabular}


Table 2.4. Summary statistics for the subset of fish recaptured at spring migrant traps per original release group. All pre-winter measurements were taken at the hatchery prior to release in each study stream and all spring measurements took place at the spring migrant smolt traps. $\mathrm{PW}=$ pre-winter measurement, $\mathrm{MN}=\mathrm{Mean}, \mathrm{SD}=\mathrm{Standard}$ Deviation, FL $=$ fork length, Weight $=$ WT, $K=$ Condition factor, Rel. $=$ Relative, GR $=$ growth rate, DUT $=$ Dutch Bill Creek, GRE $=$ Green Valley Creek, MIL $=$ Mill Creek, WIL $=$ Willow Creek.

\begin{tabular}{|c|c|c|c|c|c|c|c|c|c|}
\hline $\begin{array}{l}\text { Study } \\
\text { Stream }\end{array}$ & $\begin{array}{l}\text { PIT-tagged } \\
\text { fish } \\
\text { recaptured }\end{array}$ & $\begin{array}{l}\text { Recapture } \\
\text { date range }\end{array}$ & $\begin{array}{l}\text { MN PW } \\
\text { FL +/- SD } \\
(\mathbf{m m})\end{array}$ & $\begin{array}{l}\text { MN PW } \\
\text { Relative FL } \\
+/- \text { SD }\end{array}$ & $\begin{array}{l}\text { MN PW } \\
\mathbf{K}+/-\mathbf{S D}\end{array}$ & $\begin{array}{l}\text { MN PW } \\
\text { Weight +/- } \\
\text { SD (g) }\end{array}$ & $\begin{array}{l}\text { MN Spring } \\
\text { Relative FL } \\
\text { +/- SD }\end{array}$ & $\begin{array}{l}\text { MN } \\
\text { Spring FL } \\
+/- \text { SD } \\
(\mathbf{m m})\end{array}$ & $\begin{array}{l}\text { MN Growth } \\
\text { Rate +/- SD } \\
(\mathbf{m m} / \text { day })\end{array}$ \\
\hline DUT & 31 & $\begin{array}{l}3 / 24 / 15- \\
4 / 27 / 15\end{array}$ & $85+/-8.8$ & $0.034+/-0.11$ & $\begin{array}{l}0.0012 \\
+/-0.0\end{array}$ & $7.9+/-2.6$ & $\begin{array}{l}-0.0018+/- \\
0.07\end{array}$ & $108+/-7.7$ & $\begin{array}{l}0.00116+/- \\
0.0\end{array}$ \\
\hline GRE & 80 & $\begin{array}{l}3 / 29 / 15- \\
6 / 11 / 15\end{array}$ & $90+/-11$ & $0.060+/-0.13$ & $\begin{array}{l}0.0012 \\
+/-0.0\end{array}$ & $9.3+/-3.3$ & $\begin{array}{l}0.0028+/- \\
0.08\end{array}$ & $118+/-9.1$ & $0.0013+/-0.0$ \\
\hline MIL & 82 & $\begin{array}{l}3 / 11 / 15- \\
5 / 6 / 15\end{array}$ & $82+/-9.2$ & $0.028+/-0.12$ & $\begin{array}{l}0.0012 \\
+/-0.0\end{array}$ & $7.0+/-2.3$ & $-0.013+/-0.09$ & $\begin{array}{l}112+/- \\
10.0\end{array}$ & $0.0014+/-0.0$ \\
\hline WIL & 85 & $\begin{array}{l}4 / 14 / 15- \\
5 / 30 / 15\end{array}$ & $66+/-4.3$ & $\begin{array}{l}-0.0055+/- \\
0.066\end{array}$ & $\begin{array}{l}0.0012 \\
+/-0.0\end{array}$ & $3.3+/-0.8$ & $\begin{array}{l}0.0000+/- \\
0.09\end{array}$ & $101+/-8.6$ & $0.0013+/-0.0$ \\
\hline
\end{tabular}


Table 2.5. Random forest regression model summaries.

\begin{tabular}{lccc}
\hline Response variable & $\begin{array}{l}\text { Percent Variance } \\
\text { explained (Pseudo } \boldsymbol{R}^{\mathbf{2}} \text { ) }\end{array}$ & Sample size & $\begin{array}{l}\text { Mean square } \\
\text { residuals }\end{array}$ \\
\hline Upstream detection site & 80.0 & 1291 & 538.3 \\
movement day & 73.9 & 758 & 128.0 \\
Downstream detection & & & \\
site movement day & 70.8 & 219 & $6.78 \times 10^{-8}$ \\
Growth rate & & & \\
\hline
\end{tabular}


Figures

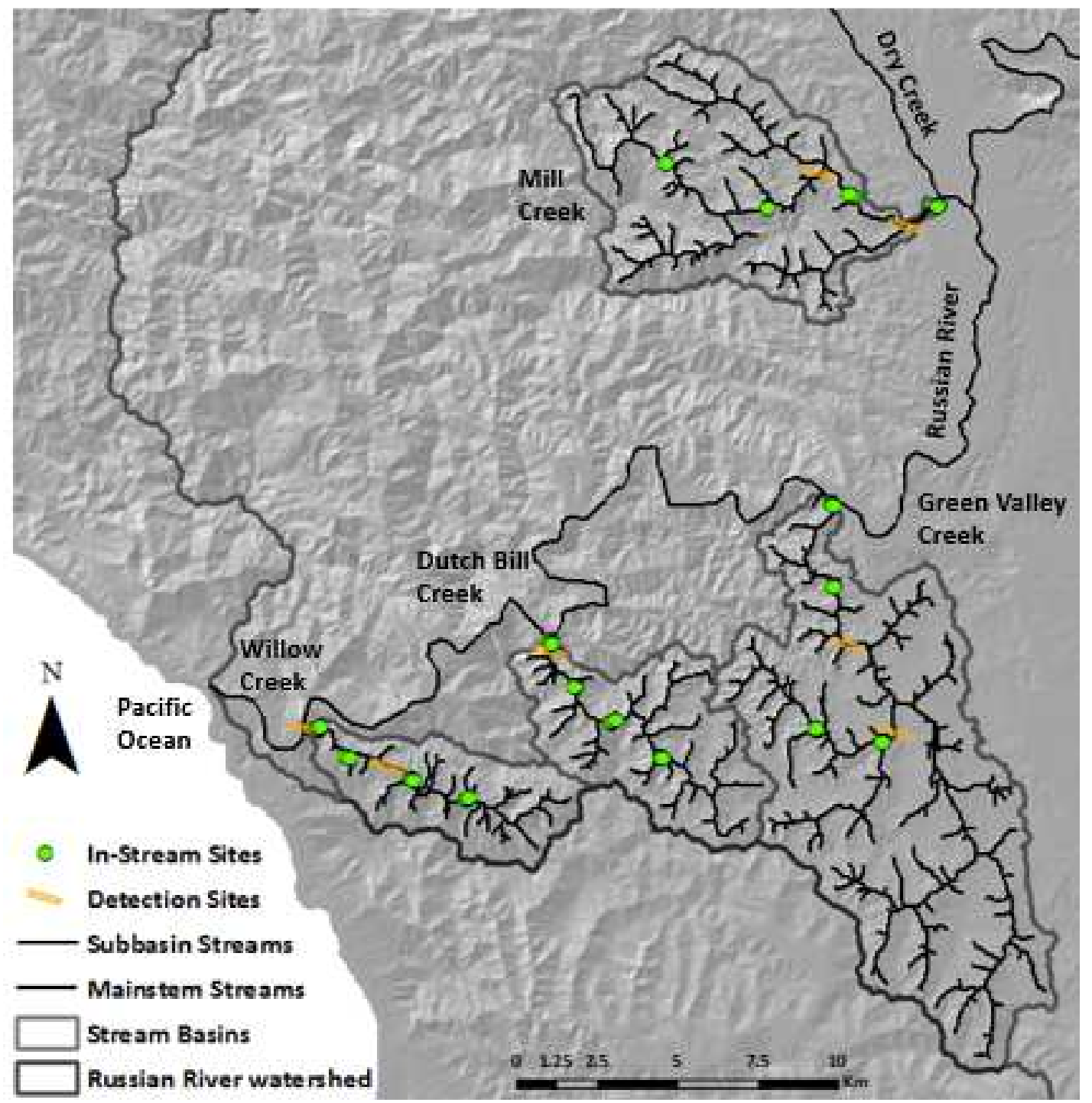

Figure 2.1. The four study stream basins in the Russian River watershed, northern California. Upslope influences on detection sites are delineated per upstream and downstream detection site. Main stem tributaries (Dry Creek and Russian River) are labeled. 


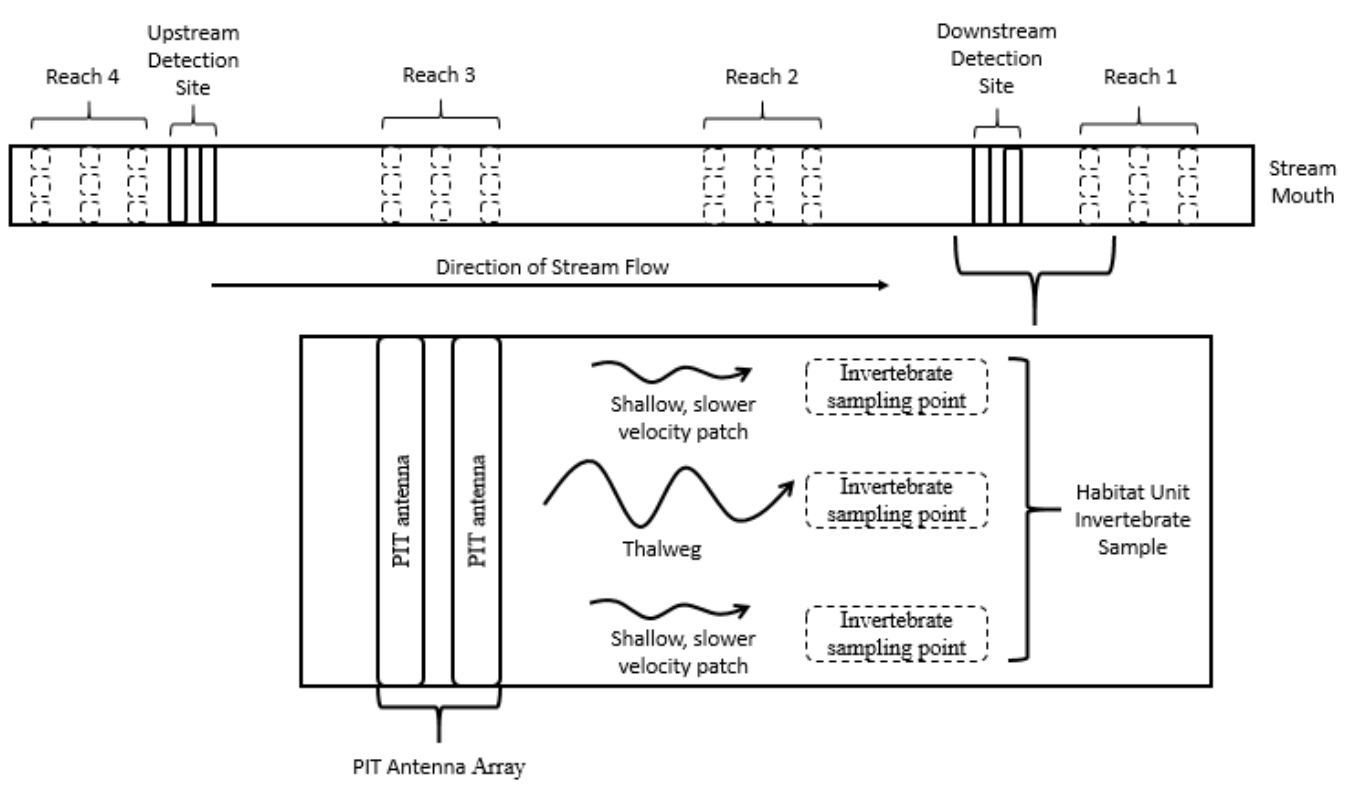

Figure 2.2. Diagram of PIT detection and in-stream sampling reach distribution across a stream. Paired antennas improve detection efficiency per site, and were used as the site design for all but one site in this study, the GRE upstream basin detection site. Macroinvertebrate and in-stream physical habitat measurements were composited per habitat unit and across four reaches per study stream to represent microhabitat and reach-scale variability. Physical habitat metrics were collected to represent the whole habitat unit, and were thus not collected only at microhabitat sampling points. 


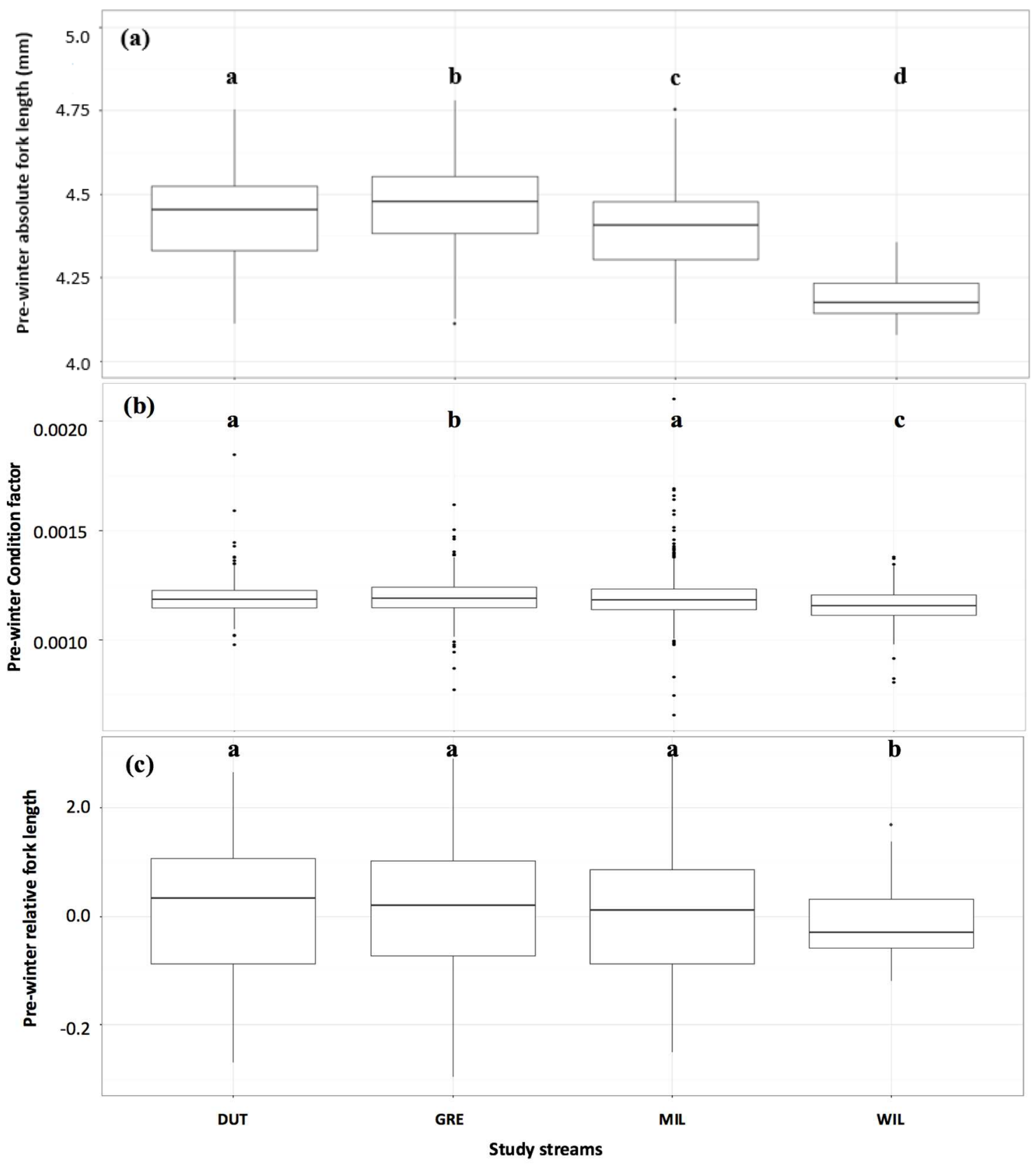

Figure 2.3. Distribution of all detected individuals pre-winter (a) absolute fork length $\left(\log _{10^{-}}\right.$ transformed), (b) pre-winter Condition factor, and (c) pre-winter relative fork length ( $\mathrm{n}=$ 1779) among the four study streams. Boxplots denote the median value with the box limits extending to the upper (75th percentile) and lower (25th percentile) quartiles. Whiskers extend 1.5 times beyond the interquartile distance of the median, with observations beyond these extents represented as open circles. Letters above study streams represent significantly different pairwise comparisons $(p<0.05)$. 

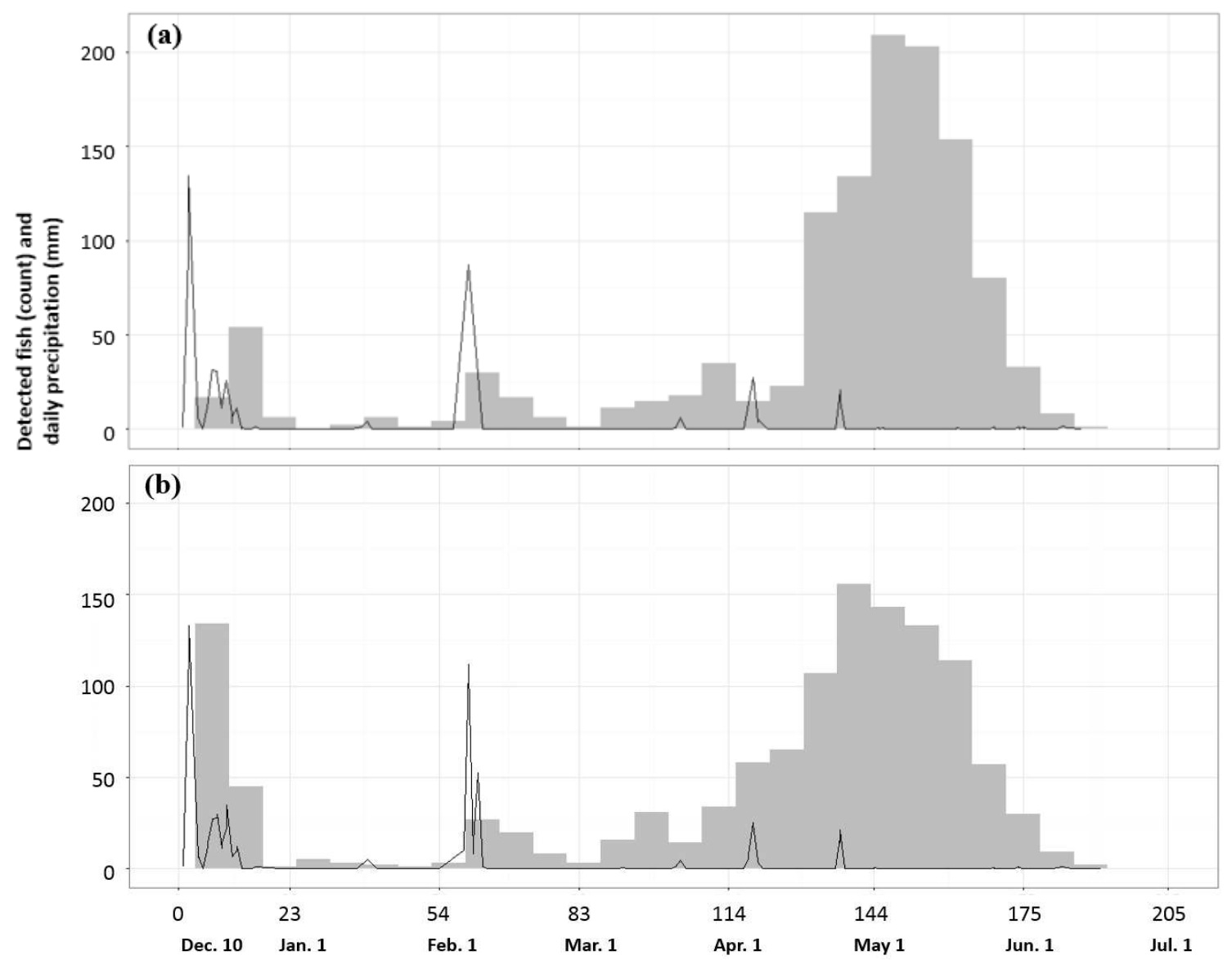

Figure 2.4. Individual fish movement day past (a) upstream detection sites $(\mathrm{n}=1291)$ and $(b)$ downstream detection sites $(n=1246)$. Counts are grouped by week-long intervals (gray bars), with day 1 occurring on December 10, 2015 (month included below movement days). Total daily precipitation $(\mathrm{mm})$ per movement day is included for reference (black line). 


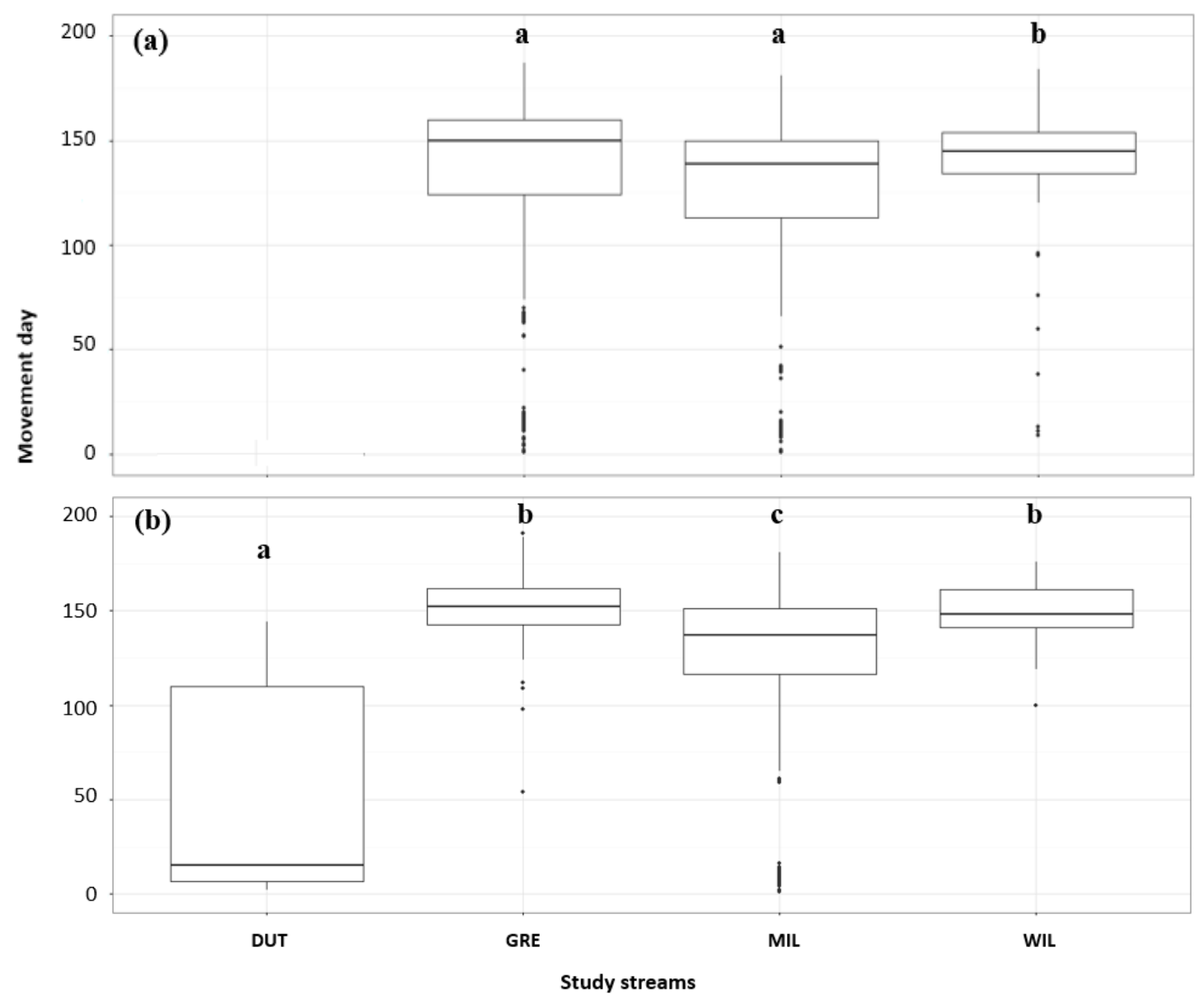

Figure 2.5. Individual fish movement day past (a) upstream detection sites (three streams, $n=1291$ ) and (b) downstream detection sites (four streams, $n=1246$ ). Box and whiskers as in Figure 3. Letters above study streams represent significantly different pairwise comparisons $(p<0.05)$. 


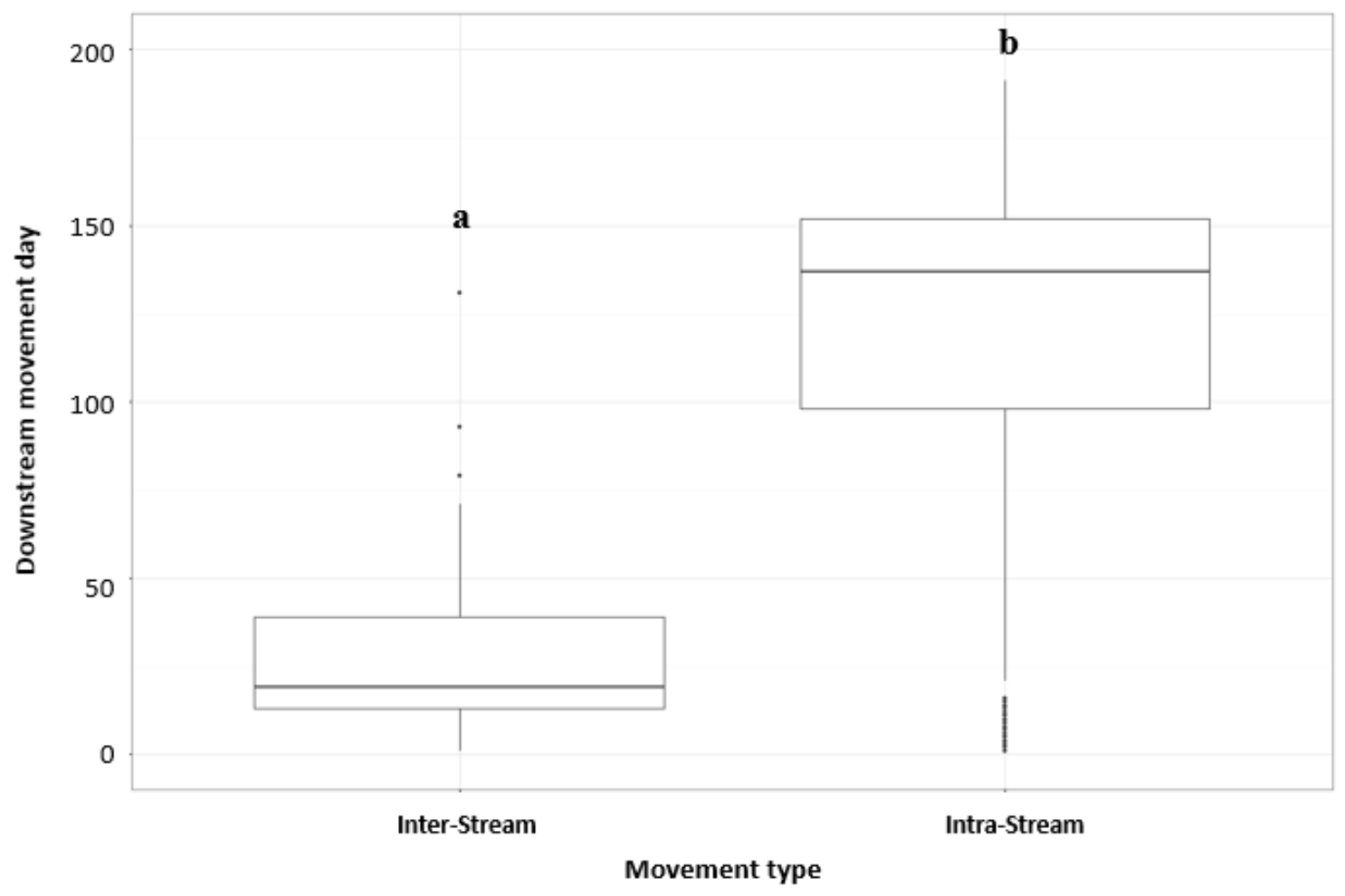

Figure 2.6. Individual movement day past downstream detection sites for interstream detected fish (three streams, $n=42$ ) and intra-stream detected fish (four streams, $n=1246$ ). Movement day is the maximum movement day past downstream detection sites for intra-stream group, and minimum movement day past downstream detection sites for inter-stream groups. Box and whiskers as in Figure 3. Letters above study streams represent significantly different pairwise comparisons $(p<0.05)$. 

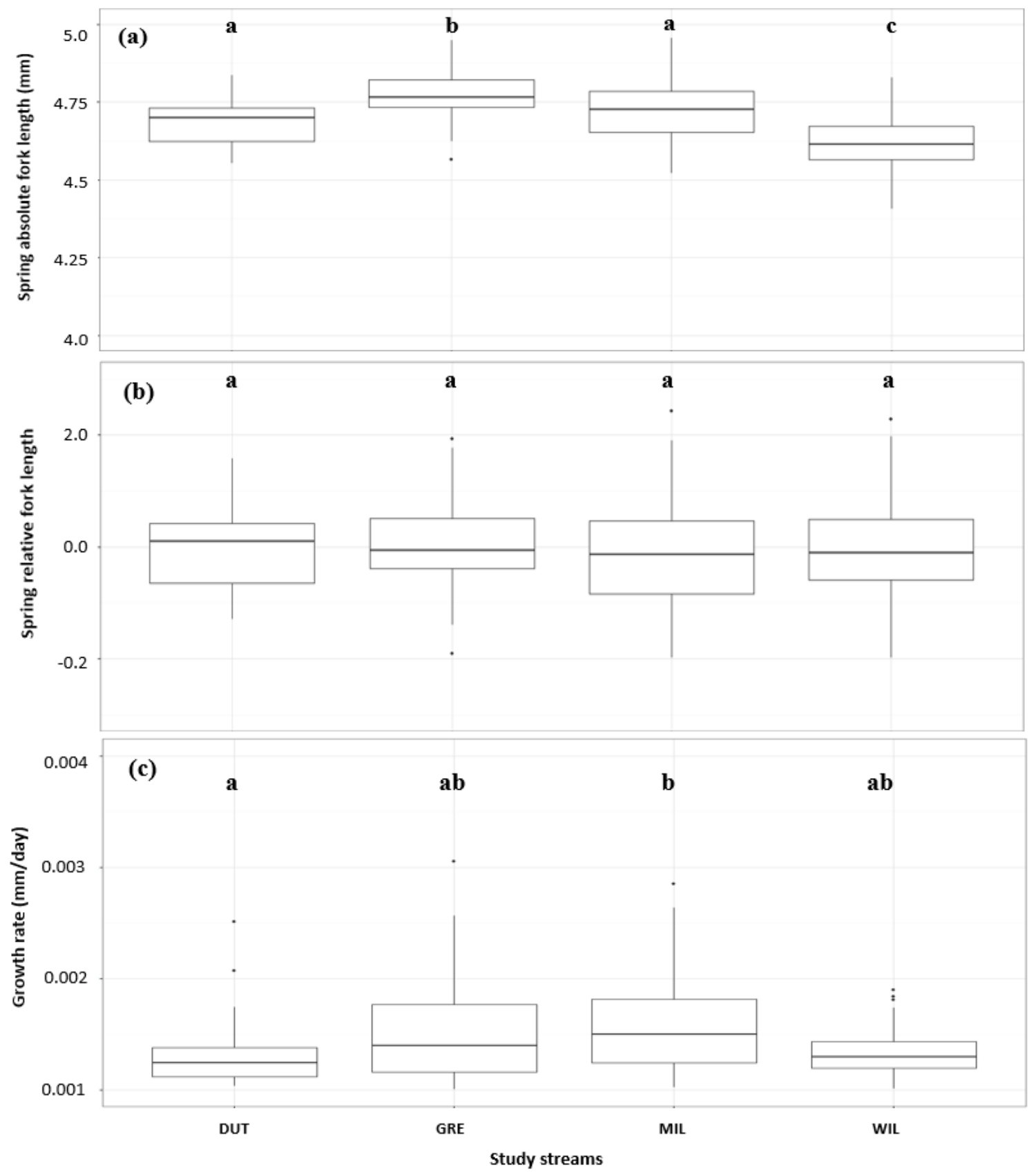

Figure 2.7. Distribution of (a) absolute fork length (log10-transformed), (b) relative fork length, and $(c)$ growth rate $(n=219)$ of all spring recaptured individuals among the four study streams. Box and whiskers as in Figure 3. Letters above study streams represent significantly different pairwise comparisons $(p<0.05)$. 


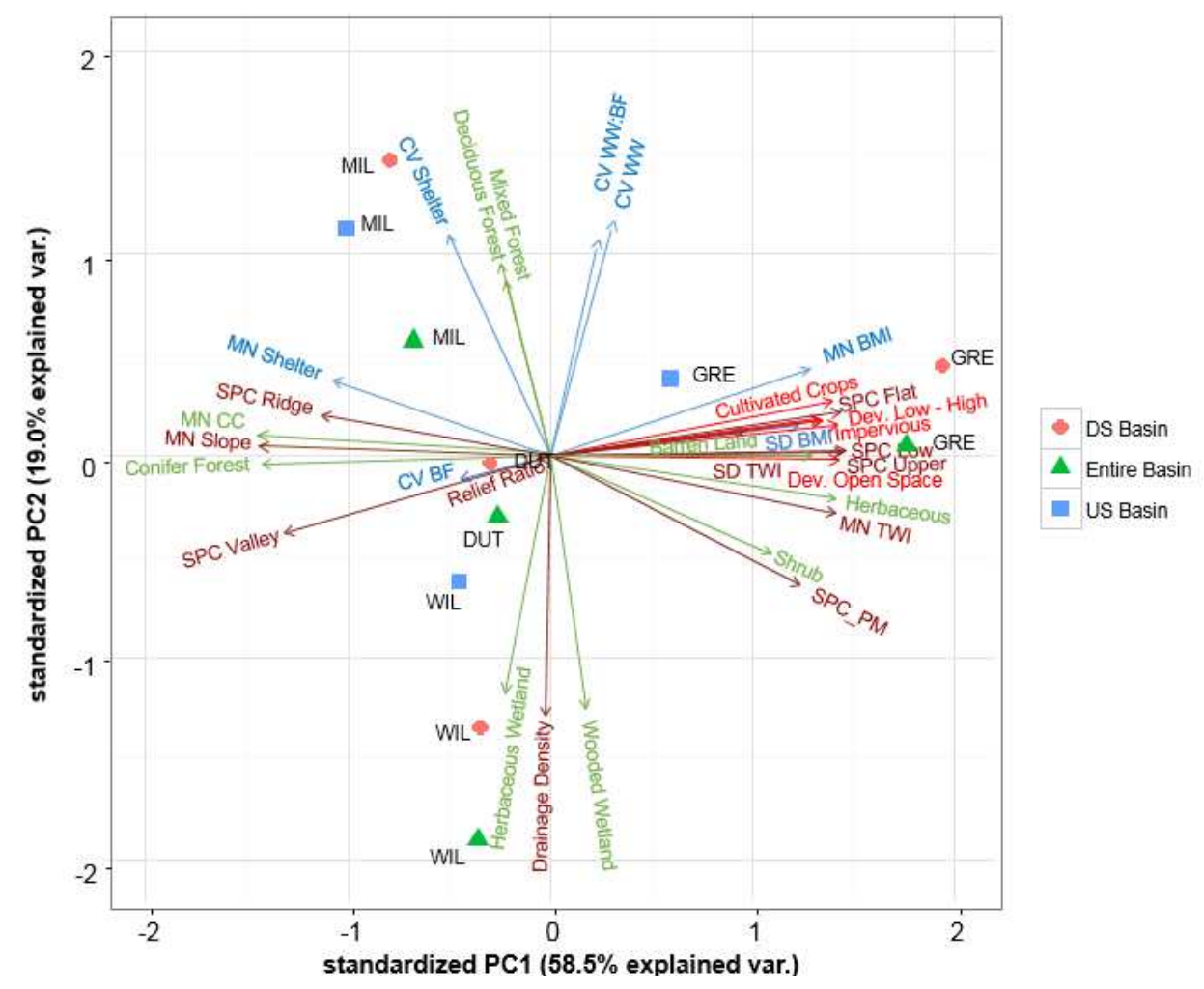

Figure 2.8. PCA for all basin-scale landscape variables across the three basin types. Site scores are indicated by symbols representing basin type (circle $=$ downstream, triangle $=$ entire basin, square=upstream) and stream name. In-stream variable labels and vectors are in blue, vegetation in green, geomorphology in brown, and agriculture and development in red. Full variable descriptions in Appendix B. Abbreviations for in-stream variables on figure are: mean benthic invertebrate abundance (MN BMI), standard deviation of mean benthic invertebrate abundance (SD BMI), mean in-stream shelter rating (MN Shelter), coefficient of variation of mean in-stream shelter rating (CV Shelter), coefficient of variation in wetted width (CV WW), coefficient of variation in bankfull width (CV BF), coefficient of variation in ratio of wetted width to bankfull width (CV WW:BF).

Abbreviations for vegetation on figure are mean \% coverage of: canopy coverage (MN CC), conifer trees (Conifer Forest), deciduous trees (Deciduous Forest), mixed trees (Mixed Forest), herbaceous plants (Herbaceous), shrub and scrub (Shrub), wooded wetlands (Wooded Wetland), herbaceous wetlands (Herbaceous Wetland), bare ground (Barren Land). Abbreviations for geomorphology variables on figure are: Slope (MN Slope, Slope Position Classification Valley (SPC Valley), Low Slope (SPC Low), Flat Slope (SPC Flat), Middle Slope (SPC Mid), Upper Slope (SPC Upper), Ridge (SPC Ridge), Mean Basin Topographic Wetness Index (MN TWI), Standard Deviation of Mean Topographic Wetness Index (SD TWI). Abbreviations for agriculture and development variables on figure are \% cover: open space development (Dev. Open Space), low intensity development (Dev. Low), medium intensity development (Dev. Med), high intensity development (Dev. High), cropland (Cultivated Crops), and impervious surface (Impervious). 


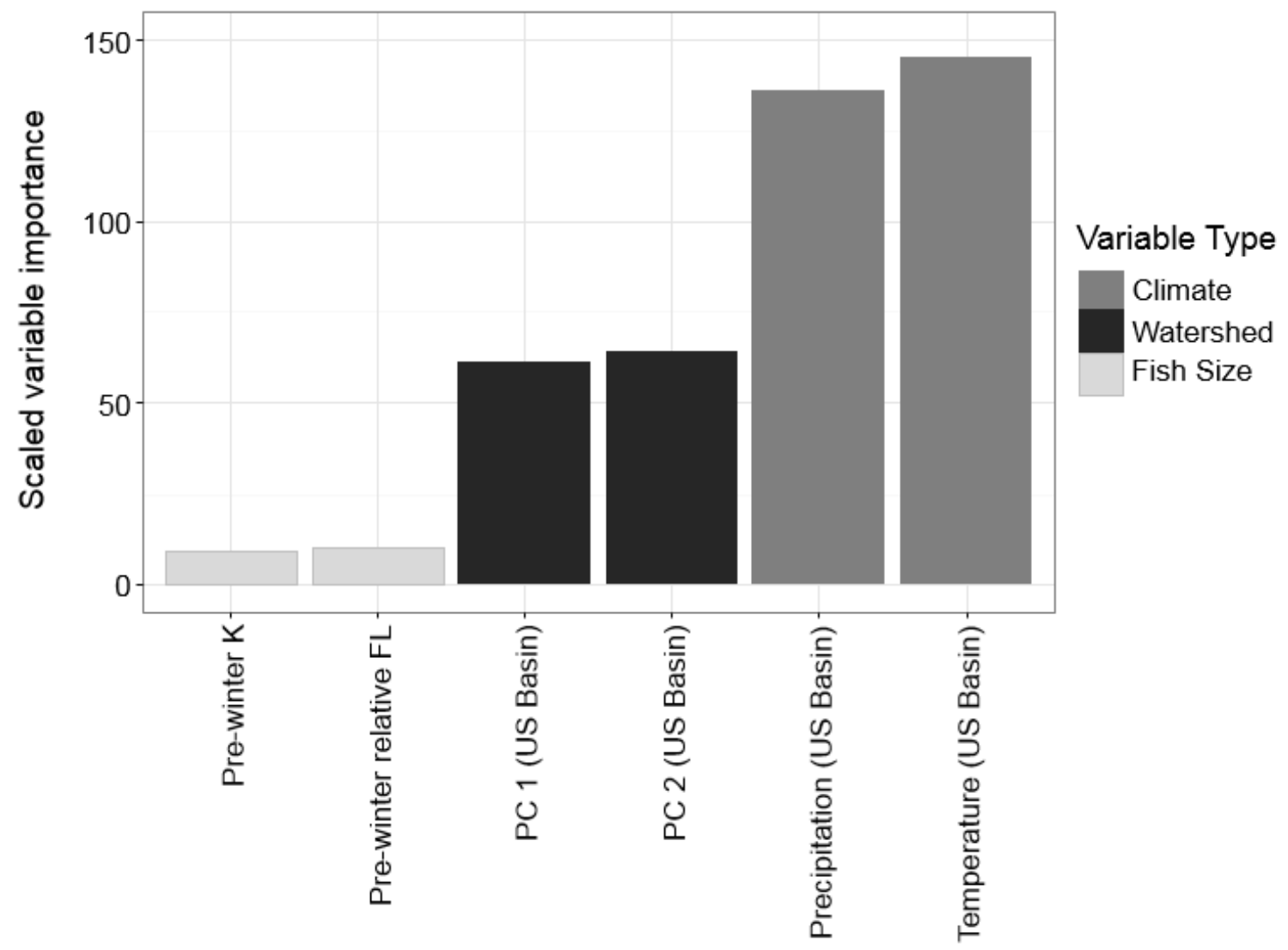

Figure 2.9. Variable importance values for upstream movement day random forest model $(n=1291)$. Variable importance is scaled (mean decrease in model accuracy percentage/standard deviation). Variable name is listed on the $x$-axis with variable types included on the right-hand side. Variable names included basin type when multiple basins are included in the model for that variable. $K=$ Condition factor, $\mathbf{F L}=$ fork length, $\mathbf{U S}=$ upstream, $\mathbf{D S}=$ downstream, $\mathrm{PC}=$ principal component. 

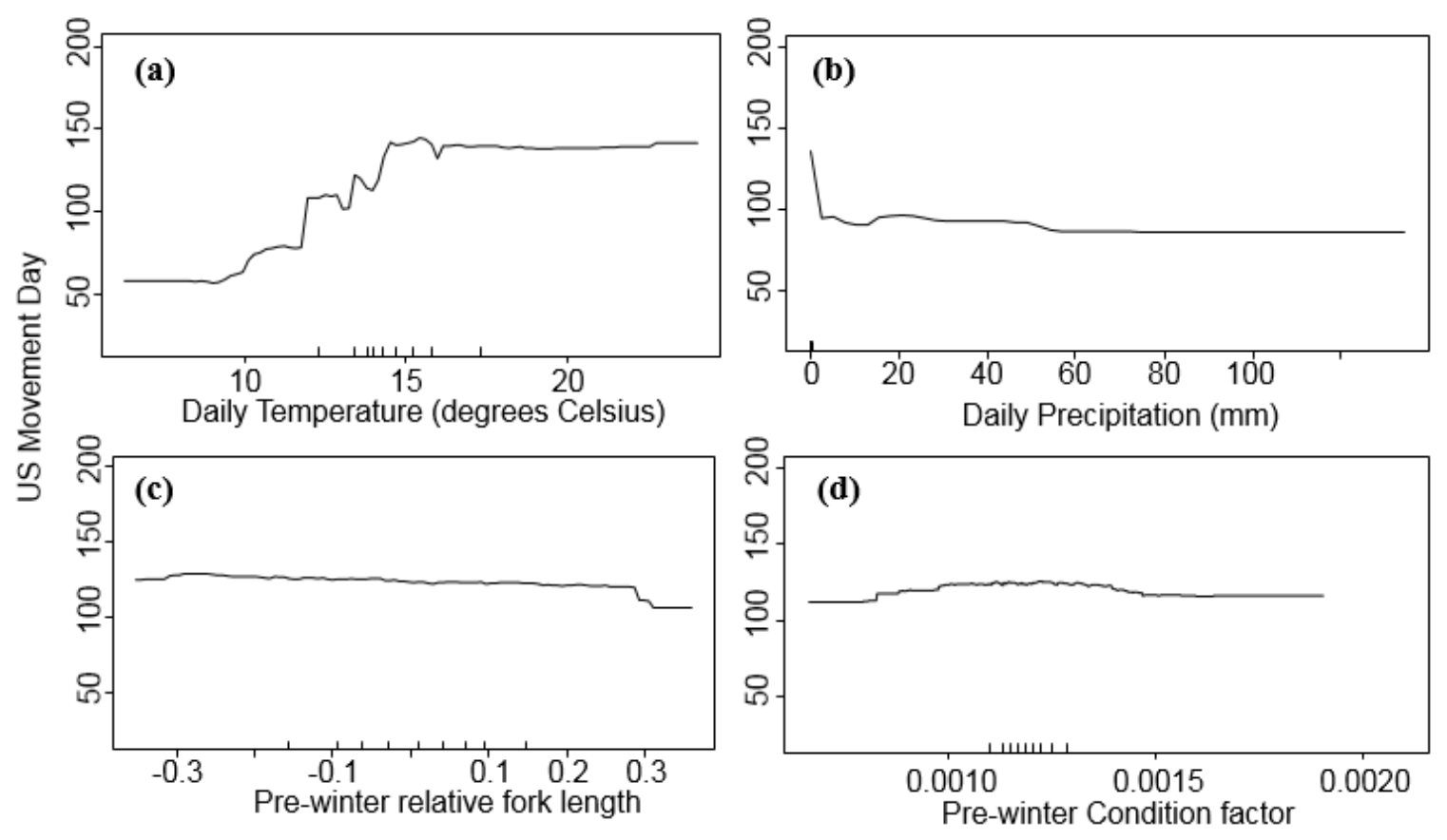

Figure 2.10. Partial dependence plot for upstream movement day versus the four most important non-watershed variables $(n=1291)$. a) Upstream daily temperature (degrees Celsius), b) Upstream basin daily precipitation ( $\mathrm{mm})$, c) Pre-winter relative fork length, d) Pre-winter Condition factor. Partial dependence plots depict the impact of one predictor on the response if all other predictors are held constant. 


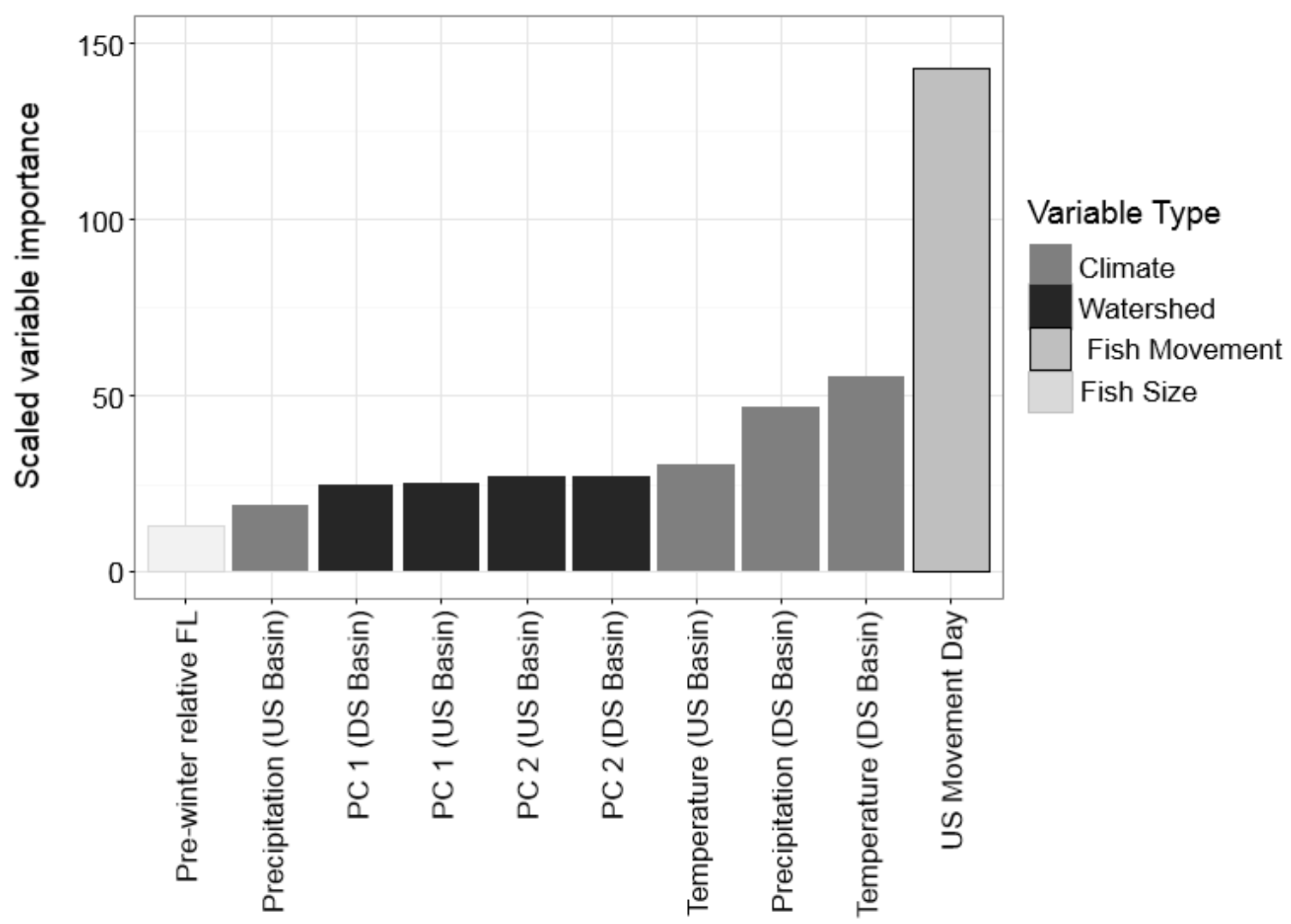

Figure 2.11. Variable importance values downstream movement random forest model $(n=758)$. Variable importance is scaled (mean decrease in model accuracy percentage/standard deviation). Variable names are listed on the $x$-axis with variable types included on the right-hand side. Variable names included basin type when multiple basins are included in the model for that variable. $F L=$ fork length, $K$ = Condition factor, $\mathrm{US}=$ upstream, $\mathrm{DS}=$ downstream, $\mathrm{PC}=$ principal component. 

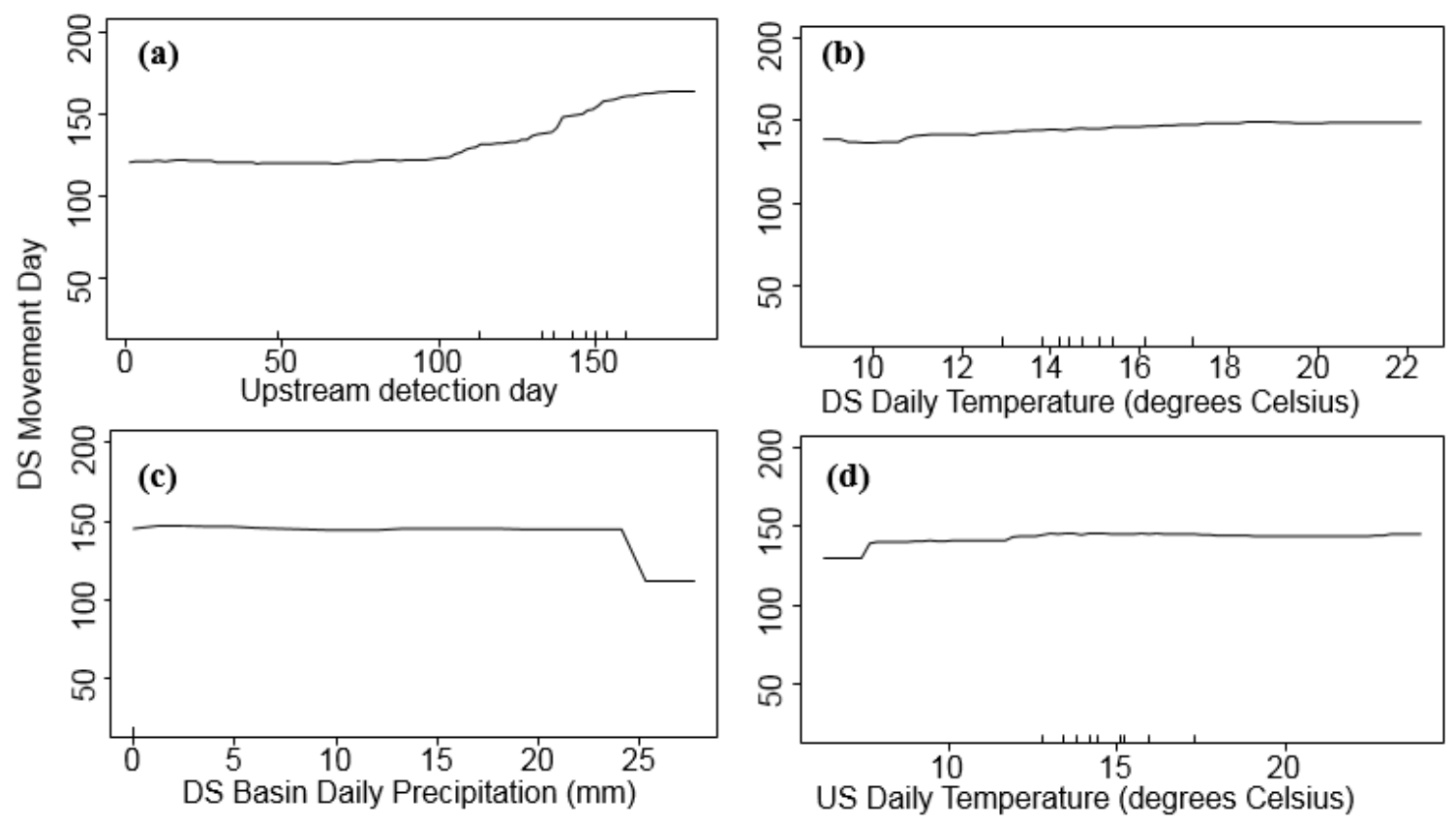

Figure 2.12. Partial dependence plot for downstream movement day versus the most important variable (a) through the fourth most important variable (d) $(n=758)$, where a) Upstream movement day, b) Daily downstream basin temperature (degrees Celsius), c) Daily Downstream basin precipitation (mm), d) Daily Upstream basin temperature (degrees Celsius). Partial dependence plots depict the impact of one predictor on the response if all other predictors are held constant. 


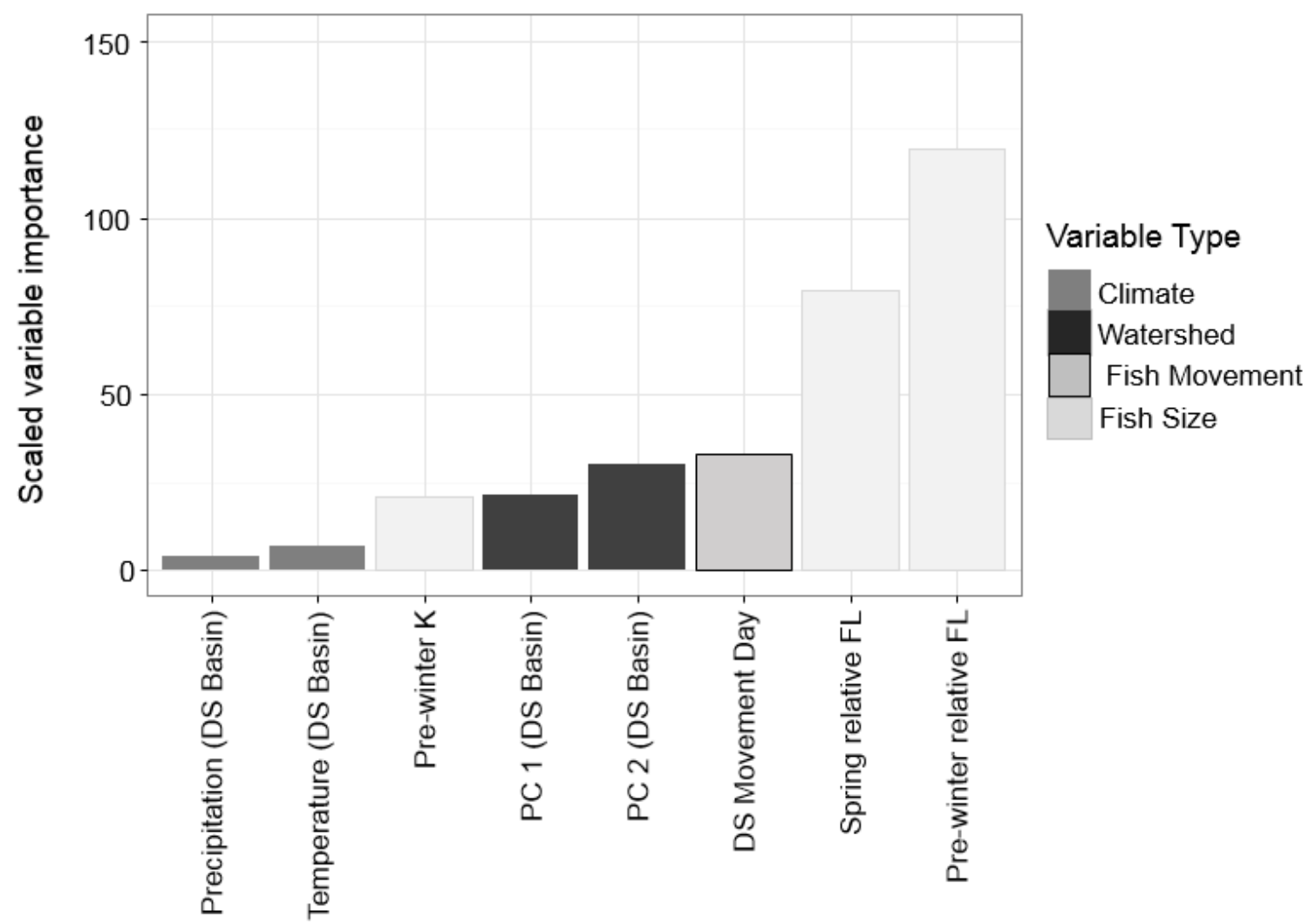

Figure 2.13. Variable importance values for the growth rate random forest model (n = 219). Variable importance is scaled (mean decrease in model accuracy percentage/standard deviation). Variable names are listed on the $x$-axis with variable types included on the right-hand side. Variable names included basin type when multiple basins are included in the model for that variable. $F L=$ fork length, $K$ $=$ Condition factor, $\mathrm{US}=$ upstream, $\mathrm{DS}=$ downstream, $\mathrm{PC}=$ principal component. 


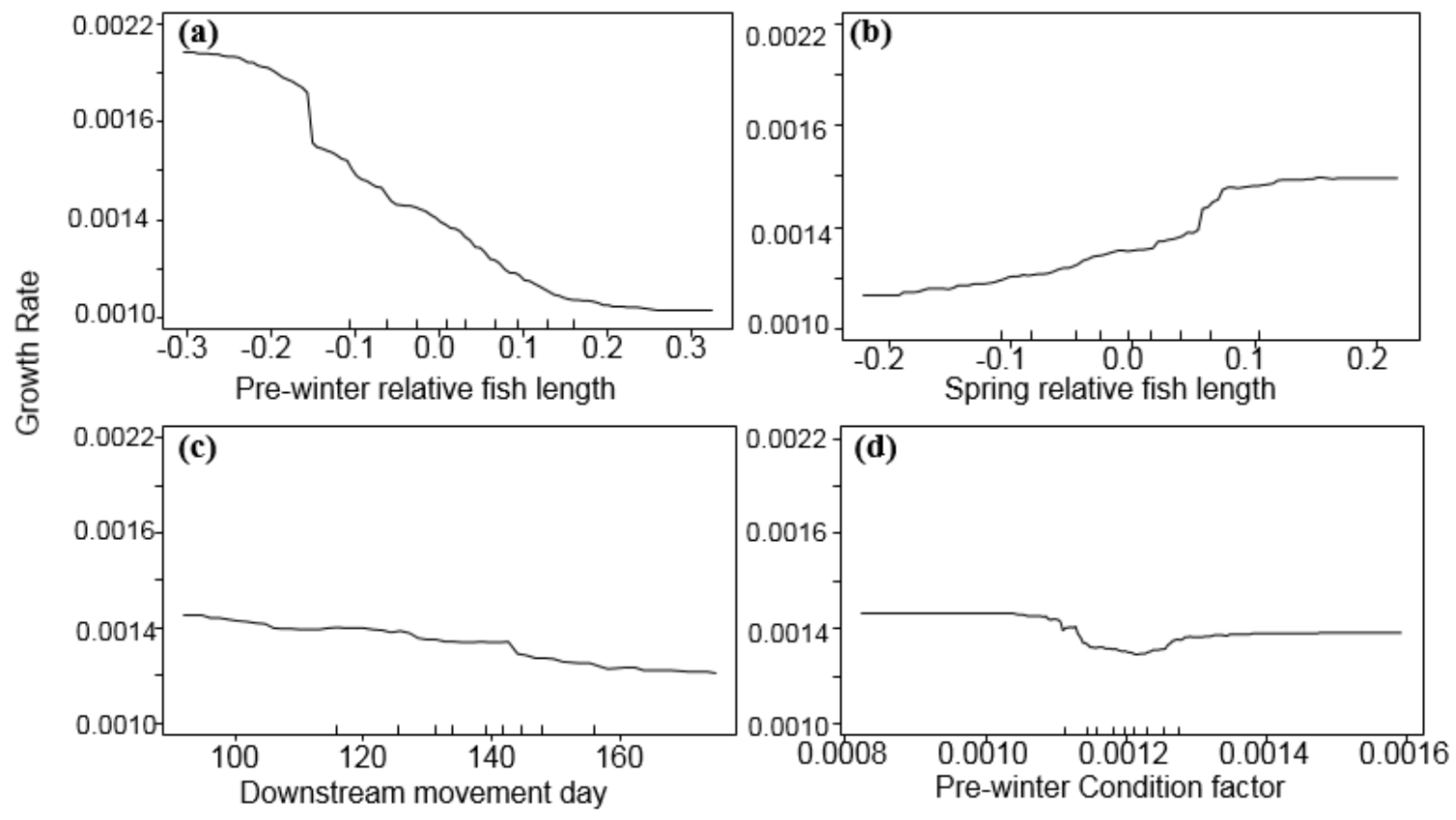

Figure 2.14. Partial dependence plot for growth rate $(\mathrm{mm} / \mathrm{day})$ versus the most important variable (a) through the fourth most important variable $(d)(n=219)$, where a) pre-winter relative fork length $(\mathrm{mm})$, b) spring relative fork length $(\mathrm{mm})$, c) downstream movement day, and d) pre-winter Condition factor (ratio of forklength $(\mathrm{mm})$ to body weight $(\mathrm{g})$. 


\section{Chapter 3 : Documenting diversity: Evidence of multiple life history strategies across the North American range of coho salmon (Oncorhynchus kisutch)}

\section{Introduction}

Conservation and recovery actions require an understanding life history strategies, including ecosystem-scale interactions among species of concern and their environment. The expression of a species life history reflects the interplay between genetically-based traits, the environment, and phenotypic plasticity in trait expression (Waples et al. 2001). Unique life history strategies occur when variation in timing of movement, fish size, and maturation exist within specific populations and species (Waples 1991). Life histories of Pacific salmon (Oncorhynchus spp.) are especially complex because of their anadromous life cycle, and reliance upon marine, estuary, and freshwater systems (Groot et al. 1995, Quinn 2005). Salmon ecology is extensively studied because of its commercial and cultural importance, as well as the decline of many populations, and their subsequent listings under the US Federal Endangered Species Act (ESA) (National Research Council 1996).

Phenotypic expression of Pacific salmon traits can be highly localized because of the association of populations with specific watersheds. Speciation occurred across the dynamic watersheds that drain into the Pacific Ocean, with surviving populations adapted to the seasonal shifts of river and estuary ecosystems (Waples et al. 2008). This evolution, in combination with the strong homing tendency of salmon, has led to highly diverse, localized life history strategies, including seasonal freshwater habitat shifts, and flexible timing of maturation and migration (Taylor 1991, Waples et al. 2001, Quinn 
2005). For instance, studies have noted that variability in smolt size and timing of emigration are correlated with latitude in sockeye salmon (O. nerka) (Freshwater et al. 2016) and with spawning abundance and flow regimes in Chinook salmon $(O$. tshawytscha) ( Beechie et al. 2006, Zimmerman et al. 2015).

One component of salmon life history that is essential to population recovery is the process of smolt outmigration, which represents the cumulative freshwater rearing of individuals prior to their adult, marine residency. Coho salmon (O. kisutch) have the longest freshwater residency of the anadromous Pacific salmon, spending one to two years in freshwater (Shapovalov and Taft 1954, Sandercock 1991). Coho salmon rearing shifts seasonally as well, with fish relying on cold, main channel pools during the summer months and inundated floodplain channels, ponds, and ephemeral upper watershed tributaries during winter floods (Tschaplinski and Hartman 1983, Nickelson et al. 1992). These unique movement strategies during the winter can result in differential outmigration timing and smolt size because of variability in growth potential in these different rearing and foraging habitats (Craig et al. 2014, Rebenack et al. 2015), as well as varied smolt survival to spawning age (Jones et al. 2014, Bennett et al. 2014).

Growth potential is an important aspect of freshwater rearing because of its strong association with survival to smolt life stages (Quinn and Peterson 1996, Ebersole et al. 2006). Juvenile salmon growth potential is dependent upon energy requirements for other needs, such as foraging, predator avoidance, and competition for resources (Fausch 1984, Nielsen 1992). Energy allotments are strongly dependent upon the quality of habitat and population density, since these control resource availability. It is well established that 
juvenile coho salmon prefer low-velocity, cold water pools with abundant invertebrate drift and complex shelter structures, including large wood, undercut banks, vegetation, and boulders (Bustard and Narver 1975, Tschaplinski and Hartman 1983, Roni and Quinn 2001, Rosenfeld et al. 2005). However, competition for these habitats can be especially high during the winter season, when high quality refugia are limited by increased stream flows in main channel pools and lack of floodplain habitat because of degraded conditions that reduce connectivity (Nickelson et al. 1992).

At larger spatial scales, temperature and flow regimes can strongly influence growth potential and habitat quality. Seasonal precipitation and temperature interact and affect habitat connectivity, controlling fish growth and movement across watersheds. Landscape characteristics mediate fish growth by providing complex floodplain shelter, food resources, and temperature moderation (Tockner et al. 2000, Wipfli and Baxter 2010). Riverine landscapes change drastically across seasons, especially in regions with highly seasonal precipitation patterns, such as the west coast of North America. Winter rains and spring snowmelt can change watershed habitat quality by reconnecting floodplains and ephemeral, headwater streams, as well as decreasing temperatures and increasing stream flows.

When the effects of large-scale landscape patterns on in-stream habitat (e.g., shelter complexity), food availability, and fish population density are considered, a more complete understanding of the underlying basis of life history variability is possible. Understanding these relationships for coho salmon prior to outmigration to the ocean is important because limited survival and growth during this stage can have population- 
scale impacts. Salmon-habitat interactions are extensively studied because of the loss of populations and subsequent habitat restoration efforts (Roni et al. 2008, Bisson et al. 2009). Multiple studies have documented patterns in movement and growth of coho salmon, but these studies are restricted to specific basins or regions. Understanding patterns across the wide range of coho salmon may improve our ability to compare and differentiate among the drivers of juvenile movement and growth patterns.

In this literature review I synthesize published literature on coho salmon movement and growth patterns prior to smolt outmigration. Comparisons will be made among identified unique pre-smolt movement behaviors as well as the influences of landscape and fish size on observed movement and growth patterns. Conclusions will be drawn regarding which variables most commonly influence movement and growth, differences in population diversity, knowledge gaps, and how current knowledge and future research can address recovery and conservation efforts focused on coho salmon across North America.

\section{Methods}

I used the online reference database Web of Science to review papers published from the beginning of the database ( 1900) through 4 April 2016. This limited my potential sources to peer-reviewed, scientific publications and excluded the gray literature. My study is not an exhaustive list of all research conducted on coho salmon juvenile behavior prior to smolt migration; laboratory experiments, literature on behavior 
in specific habitat patches, gray literature, and studies comparing abundance or smolt biomass were excluded when growth and movement timing were not considered across a watershed. Search criteria included species, life stage, and response terminology: "coho salmon", "smolt", "parr", “juvenile", "migration”, "emigration”, "movement”, "winter”, and "spring". Additional references were located based on citations from articles returned during Web of Science searches.

Data collected from studies included river mouth latitude, basin area, land use, ESA population status, study years, and the abiotic and biotic variables considered in evaluating influences on coho movement and growth. Not all of these parameters were found directly from reviewed articles (e.g., land use, population status). These incomplete records were supplemented by information from references within the articles as well as federal reports defining metapopulations (Evolutionary Significant Unit, ESU), geographic ranges, and ESA listing status. When multiple basins or populations were included in a publication, basin characteristics were averaged and population status was based on the most vulnerable listing (e.g., Threatened when one population is a Species of Concern and another is Threatened). These basin-scale and metapopulation-scale variables were noted to determine how life history diversity may be related to how vulnerable a population is (ESA listing) or the watershed size and location may be correlated to movement and growth diversity across the North American range of coho salmon, or species-scale diversity. Length of study was also noted to consider how potential for inter-annual variability (i.e., variable results among study years) within a single study may impact noted growth and movement patterns. 
Spatial as well as temporal rearing and movement diversity were considered, including pre-smolt movement by fry (initial free-swimming life stage), parr (freeswimming, less than one year of age), age- 1 smolts, and age-2 smolts (where longer freshwater rearing occurs in northern populations) (Sandercock 1991, Quinn 2005). Movement is defined as seasonal passage from one habitat type to another, i.e., spring smolt outmigration or parr leaving their natal stream during the winter. Seasonality of movement strategies were classified based on the season of final timing of outmigration for an individual, so spring for all individuals that ultimately left freshwater rearing habitat during the spring season and as a fall or winter if individuals did not return to freshwater after this outmigration season.

The number of unique movement strategies were tabulated and related to rearing habitat types in each reviewed study. This was to consider potential correlations between habitat types and movement diversity per basin, or phenotypic plasticity within a watershed population related to habitat. Strategies were tabulated if noted as unique from other strategies observed in a reviewed study. For example, two spring smolt strategies were counted if a study observed that outmigrating spring smolts either reared in their natal stream during the winter or reared in estuarine habitat during the winter, but then moved back upstream into freshwater before outmigrating as a spring smolt. Rearing habitat types were based on study classifications (tributary, pond/lake, estuary, or mainstem habitat). Since many studies compared main stem rearing to some other rearing location, tributary, pond/lake, and estuary rearing were also standardized as off-channel to compare to main channel (i.e., the main stem rearing fish). 
My main objective was to consider commonalities as well as potential gaps in our understanding of movement and growth patterns. Therefore, the following influential factors were noted as being present or absent in study designs: 1) climate-driven processes (precipitation, stream flow, temperature, or larger-scale climatic cycles), 2) density-dependence (relative fish length or number of fish per habitat unit of measure), 3) landscape influences (riparian or upslope conditions, migration distance), 4) in-stream physical habitat metrics (habitat complexity, volume, rearing habitat type), and 5) food availability (macroinvertebrate abundance and biomass, spawner density, or primary productivity estimates)

Directional relationships that were reported for predictors and response variables in each study were also tabulated to determine similarities among studies. Directional (positive, negative) statistical significance was noted for predictor variables, as well as non-significant relationships. These directional effects were defined as positive when an increase in quantity or quality of a variable was significantly correlated with either a delay in timing of movement (spring-smolt) or an increase in growth. Directional effects were defined as negative when an increase in quantity or quality of a variable was significantly correlated with earlier movement (pre-spring smolt movement) or lower growth, and defined as neutral when no statistically significant correlation was observed. Some studies measured both movement and growth patterns while others only considered one. Additionally, growth was indirectly considered in some studies by comparing prewinter and spring fish sizes. These were categorized as growth measurements in my study 
(i.e., larger smolts were categorized as having positive growth in comparison to smaller smolts within a single study).

Pacific salmon population resilience is influenced by genetic and environmental interactions, since individuals can adapt to local environments through their phenotypic expression. This phenotypic plasticity allows individuals to adapt to resource availability. Supporting the phenotypic diversity that results from individual phenotypic plasticity is essential to population resiliency, because of the localized adaptations of individuals allow populations to respond to dynamic environments (Healey 2009, Waples et al. 2009). To address these interactions, principal components analysis (PCA) was used to assess similarity among study watershed and population characteristics, by reducing these multivariate aspects to two-dimensional, measureable space (Table 3.1). Essentially, the aim was to examine if watershed and population characteristics are correlated with significant trends in coho movement patterns and growth. Not all studies analyzed with PCA included the same predictor variables, so separate PCAs were run on a subset of studies to compare the relationship of movement strategy and diversity to rearing habitat type (16 studies) and the statistical effect of pre-movement individual fork length on fish growth (five studies). When studies found inter-annual variability in predictive relationships for fork length, data were included separately in PCA to capture variation in fish size within basins. 


\section{Results}

Eighteen studies from eighteen different coastal basins from southeast Alaska through northern California (59 to $40^{\circ} \mathrm{N}$ latitude) were analyzed for relationships between climate, watershed, and fish size on movement and growth patterns (Table 3.2, Figure 3.1, Appendix E). Studies primarily occurred in the last ten years, although longterm winter movement patterns were also documented during the 1970s and 1980s. Ten studies included $\geq 3$ years of field data collection, representing potential inter-annual variability in watershed and fish patterns. Twelve of the studies occurred in basins $<200$ $\mathrm{km}^{2}$ and all occurred within close proximity to the coast, with five studies including estuarine habitat. Population status followed a latitudinal trend, with northern populations unlisted, followed by increasing listings of Species of Concern, and Threatened populations in more southerly populations (Table 3.2). Three studies in Alaska and British Columbia also described age-1 versus age- 2 smolt outmigrations, which were noted separately from spring smolt outmigration strategies (Appendix E).

Commonalities in movement strategies and potential factors existed across studies. The majority included fish size, in-stream physical habitat, and landscape predictor variables in their analyses, while only four specifically included density-dependent processes and only three considered food availability (Table 3.3). Rearing habitat type (main stem, off-channel ponds, lakes, or tributary streams, estuary) $(n=6)$ and premovement fish length $(\mathrm{n}=8)$ were the most common reported statistics, and were used in summary data comparisons. Multiple movement patterns were evident even in southern, threatened populations as well as in small, coastal basins with limited estuary habitat and 
larger basins with extensive estuary zones (Appendix E). The number of movement strategies was also correlated with rearing habitat types: up to four strategies were documented for studies considering estuary rearing, three movement strategies were found in studies considering tributary and pond and lake rearing, while two movement strategies on average were noted for studies in which only main channel rearing was considered (Table 3.4).

Studies that reported drivers of movement patterns had varied directional relationships, with climate-driven and fish size variables having positive, negative, or neutral effects on movement (Figure 3.2, Appendix E). This means that these abiotic and biotic drivers can both be associated with later fish movement, earlier fish movement, or have no measurable effect on fish movement, depending upon the study basin, season, or year (Figure 3.2, Appendix E). In-stream habitat and landscape variables were significant predictors of the timing of movement, but were reported as both positive and negative drivers of movement, depending upon the study system (Figure 3.2). Drivers of fish movement were explored across both coarse and fine-spatial scales, with climate-driven, landscape, in-stream habitat, and fish size metrics all commonly considered, although density and stream productivity considerations were less well reported (Figure 3.2).

Drivers of growth were primarily reported for finer-scale variables, such as instream habitat and fish size metrics over climate and stream productivity variables (Figure 3.3). In-stream habitat type and quality metrics were highly positively associated with growth, meaning higher quality habitat was correlated with greater growth across reviewed studies. In fact, all studies that considered impacts of rearing habitat on fish 
growth found that off-channel rearing was positively associated with growth, whether or not rearing habitat types were ephemeral streams, side channels, ponds, lakes, or estuaries (Appendix E). By contrast, fish size had a variable influence on growth, with positive, negative, and no effect on growth all reported (Figure 3.3). Landscape variables, primarily migration distance, were most commonly negatively associated with growth, suggesting watershed location was important to growth potential (Figure 3.3). Inverse relationships between watershed location and growth suggested that lower watershed locations were more often associated with greater growth than upper watershed fish location.

The correlation of basin and population characteristics with movement timing and growth were explored using principal component analysis (PCA). The first model considered the type of and number of movement strategies per basin, and how offchannel rearing habitat types, population ESA status, length of study, and basin location may be related across the range of coho salmon (Figure 3.4, Appendix C). The first two PCA axes explained $43.4 \%$ of the total variation across studies, with PC 1 explaining $24.2 \%$ and PC 2 explaining $19.2 \%$ of total variance. Winter parr and spring smolt movement strategies were the primary variables influencing PC 1, with winter and parr movement strategy components negatively associated with PC 1 and spring and smolt movement strategy components positively associated with PC 1. PC 2 was primarily influenced by population and basin characteristics, with positive association for basin latitude and non-listed ESA status, and a negative association with Threatened ESA status and number of rearing strategies. Rearing habitat type differed along a latitudinal 
and basin area gradient as well, with main channel rearing primarily noted in northern latitude and large basins and estuary rearing primarily noted in southern, smaller basins.

The second PCA model assessed the effect of fish size on growth, with $92.3 \%$ of the total variation explained by population and basin characteristics, as well as rearing location (Figure 3.5, Appendix C). PC 1 explained the majority of variance, $66.4 \%$, and was primarily positively influenced by main-channel rearing, basin area, and Threatened ESA listing, and negatively influenced by basin latitude and Species of Concern ESA listing. PC 2 was primarily positively influenced by fish fork length and negatively influenced by the length of the study, suggesting inter-annual variability may influence the reported effect of fish size on growth. This ordination suggests that the influence of fish size on growth is not correlated to population status (e.g. vulnerable, or Threatened, populations exhibit similar patterns in growth as less vulnerable, or unlisted populations), basin area, or location across the range of coho salmon and could also vary across study years. Instead, finer-scale variables may be more important in predicting growth, such as seasonal shifts in habitat quality, density-dependent patterns, and climate cycles.

\section{Discussion}

\section{Commonalities and Gaps in Knowledge}

Multiple movement strategies prior to smolt ocean outmigration were evident across the range of coho salmon, including winter downstream movement into lower freshwater habitats and estuaries, and upstream movement into headwater streams, which were distinctly separated from peak outmigration by smolts during the spring. Although 
factors related to early movement varied, multiple studies found a correlation between increased stream flow and initial fall movement by parr, with variation in this relationship occurring among seasons and study years (Tschaplinski and Hartman 1983, Miller and Sadro 2003, Roni et al. 2012, Jones et al. 2014). Growth potential may influence early movement as well; smaller fish were more likely to move earlier than larger fish, and early movers that reared in floodplain, estuary, and headwater stream habitats were often reported to grow more than main channel stream rearing fish (Thedinga et al. 1994, Bennett et al. 2011, Roni et al. 2012).

Coarse-scale and fine-scale variables were commonly considered in movement studies, including stream flow patterns, migration distances, and rearing habitat types (main channel versus tributary, estuary, or floodplain habitats) (Figure 3.2). However, comparisons among studies may be improved by providing metrics that represent the quality or relative abundance of rearing habitat types. Many studies included qualitative descriptors of watershed conditions, but pool frequencies, shelter quality, or relative abundance of specific habitat types may improve our ability to compare fish responses to watershed conditions across species' ranges, rather than within specific basins. Population or fish community densities were not commonly considered, despite established understandings of the importance of density-dependent growth and mortality even in salmon populations with low abundances (Walters et al. 2013) as well as resource partitioning that can occur among competitive Pacific salmon species (Reeves et al. 2011). Effects of productivity on fish behavior were also lacking. Food web considerations may illustrate additional ecosystem-scale patterns that are not always 
evident from studying population and abiotic patterns alone (Naiman et al. 2012).

Considering these density-dependent factors may add to our understanding of drivers of growth, since fine-scale variables like in-stream habitat were considered more frequently than population, community, or watershed considerations (Figure 3.3) and may illustrate commonalities in growth potential - habitat patterns not gleaned from coarse-scale correlations alone (Figure 3.5).

\section{Patterns in Movement Strategies}

Timing of movement (winter versus spring) was more important in differentiating study results than population or basin-specific characteristics (Figure 3.4). The significance of this is that movement occurred across multiple coho salmon populations, regardless of vulnerability (ESA listing) and basin size and location. This suggests that factors other than rearing habitat type alone influenced fish movement timing, and that movement diversity is a species-scale pattern rather than simply a population-scale pattern. Although not one specific rearing habitat type was associated with a particular movement strategy, the availability of some type of non-main channel habitat was associated with spring smolt movement, suggesting movement strategies were associated with habitat quality (Figure 3.2). For example, density-dependent processes or genetics may explain diversity in the timing of movements rather than basin-level physical habitat or population abundance characteristics as evidenced by the prevalence of movement diversity across the range of coho salmon. Winter movement has been considered a response of less fit individuals to either competition or inability to avoid winter flood 
conditions, and these individuals were often considered lost from the population (Koski 2009). This may explain why off-channel rearing was associated with spring smolt movement rather than winter-parr movement strategies in the studies reviewed (Appendix E). However, winter movement strategies may provide a population benefit by producing larger smolts (Ebersole et al. 2009b) and by winter movers contributing to returning adult spawner populations (Jones et al. 2014, Bennett et al. 2014).

Although most studies reported two distinct movement strategies, more were reported for studies in southern latitudes and when non-main channel habitats were available (Table 3.4 and Figure 3.3). This suggests that rearing habitat diversity may be important in determining how many additional movement strategies beyond winter parr and spring smolt movement are supported in a watershed. For instance, studies in Oregon reported spring and summer downstream movement to estuaries and winter inter-stream movement by juvenile coho salmon in addition to downstream winter parr and spring smolt strategies (Miller and Sadro 2003, Ebersole et al. 2006, Craig et al. 2014, Jones et al. 2014). This could also be a study design effect: basin areas were smaller in studies from southern latitudes, which may support more efficient data collection because they had narrower stream channels and shorter streams than large river basins in British Columbia and Alaska.

Patterns in Growth

No single driver of growth was evident within or across studies. Positive relationships between growth and initial fish fork length were not observed in ordination 
analysis, and the effect of fish size also changed with study length, suggesting interannual variability (Figure 3.5). Inconsistency in predictors of growth may have to do with finer-scale variables than were captured in this review, such as relative abundance and quality of rearing habitat within reviewed studies. For instance, studies comparing growth in main- versus off-channel habitat in the same basin observed greater growth in offchannel habitat as well as opposing relationships between growth and rearing habitat spatial location within a watershed and growth (Quinn and Peterson 1996, Roni et al. 2012, Rebenack et al. 2015). This suggests that winter habitat may be more important in predicting smolt survival and size than summer conditions, at least when high quality winter rearing habitat is available, regardless of its location within a watershed. This also provides an explanation for early movement to high quality rearing habitats, even when they were located upstream or in estuaries, where predation risk can increase and additional energy is required to offset costs of swimming. Greater growth associated with high risk habitats may represent an alternative to more evolutionarily conservative bethedging strategies of lower mortality risk, but lower growth associated with extended freshwater rearing. This more conservative behavior may support population persistence by reducing risk, but it also reduces variability within the population (Slatkin 1974, Wilbur and Rudolf 2006).

Growth is a complex variable, influenced by thermal conditions, energetic needs, and food availability, which can all shift quickly and frequently in stream systems. Fish can respond quickly to these changing conditions, with juvenile coho salmon observed rearing and foraging in unique thermal patches to increase their growth potential in 
Alaska (Armstrong and Schindler 2013) as well as increasing growth by feeding in higher velocity riffle habitat with greater prey densities (Rosenfeld and Raeburn 2009). Understanding spatial and temporal productivity gradients throughout watersheds may improve our understanding of growth in relationship to rearing habitat and its location within the watershed, two important drivers of growth in this review. Additional understanding of these relationships could potentially help explain the inter-annual variability observed in some studies included in this review (Appendix E).

\section{Implications}

Although many individual studies exist that assess juvenile coho salmon movement diversity and growth benefits from different habitat types, commonalities and gaps have not yet been assessed across the wide geographic range of this vulnerable and important species. This review included eighteen studies to assess drivers of diversity in timing of movement and growth to help address this knowledge gap. Although this is a relatively small sample size with limited repeatability in statistically considered variables, this review can help determine next steps forward in coho salmon recovery and habitat restoration efforts. Small sample sizes may over-emphasize observed similarities, such as the greater number of movement strategies associated with estuary habitat availability (Table 3.4). Many of these study basins included land use activities that degrade freshwater habitat and can harm populations, such as timber harvest and stream flow controls. However, most studies included land use only in basin descriptions rather than analyses. These similar landscape influences can reduce watershed habitat heterogeneity, 
leading to lower life history diversity and greater similarity across the study range, as already observed in studies of variability in the timing of return to spawn (Schindler et al. 2010, Moore et al. 2010). Land use has been linked to spatial diversity in spawning abundances (Pess et al. 2002, Andrew and Wulder 2011), so quantifying landscape impacts on juvenile fish behavior may provide additional context to observed life history diversity.

Despite degraded watersheds and vulnerable populations, at least two movement strategies were reported in all cases. This could be a publication bias or evidence that even highly impacted watersheds and populations support life history diversity in presmolt behavior. Conserving this diversity could help buffer fragile populations against disturbance. This goal could be achieved by preserving and restoring non-main channel rearing habitat connectivity during the winter season, such as estuary and off-channel pond and lake habitats, all of which were associated with distinct movement strategies and increased growth in this review. These are also highly vulnerable habitat types, due to the disproportionate loss of estuarine and floodplain habitats across the range of coho salmon (McClure et al. 2008). When these habitats are restored, Pacific salmon can adapt quickly to newly available habitats, increasing spatial and temporal distribution and resiliency of these populations (Bottom et al. 2005, Anderson et al. 2008).

Inter-annual patterns in movement and growth suggest that long-term monitoring is essential to understand population benefits of multiple rearing strategies by coho salmon. In one study, estuary rearing was associated with positive growth in comparison to stream-rearing fish during one year but negative growth in another year (Rebenack et 
al. 2015). The positive relationship between growth and survival may buffer populations against poor conditions in the long-term, even when growth benefits are only occasionally obtained from certain habitat types (Holtby et al. 1990, Quinn and Peterson 1996, Ebersole et al. 2006). In order to determine seasonal habitat and fish size associations with long term population benefits, studies need to be conducted over multiple study years.

Conserving life history variability where present, and restoring patterns that support it when absent or reduced, could increase the stability and resiliency of coho salmon populations. Watershed connectivity and habitat quality can inform potential distribution of juvenile coho salmon, and how this may affect timing of movements, smolt size, and ultimately survival. Although watersheds are unique across the wide geographic range of coho salmon, mapping and quantifying the current and historical non-main channel rearing options for coho salmon, whether they are ephemeral streams, ponds, lakes, or estuaries, could help prioritize restoration and conservation efforts. Estuaries were associated with the greatest diversity in timing of movements, and efforts to understand and protect these dynamic habitats may provide the greatest benefit to juvenile coho salmon. 


\section{Tables}

Table 3.1. Variable descriptions utilized in principle component analysis (PCA). Not all variables used in all analyses: rearing habitat effect used separately from prewinter fork length effect. Binary variables are based on whether or not that study included that variable. Effects are based on significance of variable: positive effect $(1)$, negative effect $(0)$, or no significant effect $(0.5)$ on response variable.

\begin{tabular}{|c|c|c|}
\hline Variable & $\begin{array}{l}\text { Variable } \\
\text { Type }\end{array}$ & Description \\
\hline Basin latitude & Numeric & Latitude at basin mouth (Decimal Degrees) \\
\hline Basin area & Numeric & $\begin{array}{l}\text { Drainage area }\left(\mathrm{km}^{2}\right) \text { as reported or found for the study area; } \\
\text { averaged when multiple basins analyzed in a literature study. }\end{array}$ \\
\hline Population status & $\begin{array}{l}\text { Binary } \\
\text { (presence/ } \\
\text { absence) }\end{array}$ & $\begin{array}{l}\text { Not listed or listed status for population ESU under ESA } \\
\text { (Threatened and Species of Concern). Maximum listing used } \\
\text { when multiple populations analyzed in a literature study. }\end{array}$ \\
\hline Off-channel type & $\begin{array}{l}\text { Binary } \\
\text { (presence/ } \\
\text { absence) }\end{array}$ & $\begin{array}{l}\text { Main channel (only rearing habitat considered), tributary (to } \\
\text { main channel), pond or lake, estuary. }\end{array}$ \\
\hline Movement strategy & $\begin{array}{l}\text { Binary } \\
\text { (presence/ } \\
\text { absence) }\end{array}$ & Unique life stage-movement season and life stage identified. \\
\hline $\begin{array}{l}\text { Number of } \\
\text { movement } \\
\text { strategies }\end{array}$ & Numeric & $\begin{array}{l}\text { Number of unique life stage-movement seasons identified per } \\
\text { study. }\end{array}$ \\
\hline $\begin{array}{l}\text { Pre-winter fork } \\
\text { length effect }\end{array}$ & Ordinal & $\begin{array}{l}\text { Significance of pre-winter fork length on movement strategy: } 0 \\
=\text { negative influence; } 0.5=\text { non-significant influence; } 1= \\
\text { positive influence. Positive influence equates to later movement } \\
\text { timing associated with longer pre-winter fork length, negative } \\
\text { influence equates to earlier movement timing associated with } \\
\text { shorter pre-winter fork length, and non-significant influence } \\
\text { means no effect of pre-winter fork length detected on movement } \\
\text { timing. }\end{array}$ \\
\hline
\end{tabular}


Table 3.2. Summary of study locations, population characteristics, and study timelines, organized north to south based on basin mouth latitude $(n=18)$. Study years listed are for the beginning year (fall) rather than the end of a study year (spring). If multiple basins were included in a study, latitude and basin area values listed are the mean, and population status is for the most vulnerable population. Land use includes historical and current practices. Precip = Precipitation, R = Rain, SN = Snowmelt, GL = glacier-melt, Pop. = Population, NL = Not listed, $\mathrm{SC}=$ Species of Concern, $\mathrm{Th}=$ Threatened.

\begin{tabular}{|c|c|c|c|c|c|c|c|}
\hline $\begin{array}{l}\text { Latitude } \\
\left({ }^{\circ} \mathrm{N}\right)\end{array}$ & Basin name & $\begin{array}{l}\text { Basin area } \\
\left(\mathrm{km}^{2}\right)\end{array}$ & Land use & $\begin{array}{l}\text { Precip } \\
\text { type }\end{array}$ & $\begin{array}{l}\text { Pop. } \\
\text { status }\end{array}$ & $\begin{array}{l}\text { Study } \\
\text { years }\end{array}$ & Reference \\
\hline 59.45 & Situk River, AK & 200 & Commercial harvest & $\mathrm{R}, \mathrm{SN}$ & NL & 1990 & $\begin{array}{l}\text { (Thedinga et al. } \\
\text { 1994) }\end{array}$ \\
\hline 58.28 & Taku River, AK & 16000 & Commercial harvest & GL & NL & 1987 & $\begin{array}{l}\text { (Murphy et al. } \\
\text { 1997) }\end{array}$ \\
\hline 55.82 & Staney Creek, AK & 164 & Timber harvest & $\mathrm{R}, \mathrm{SN}$ & NL & 1996 & $\begin{array}{l}\text { (Bramblett et al. } \\
\text { 2002) }\end{array}$ \\
\hline 50.70 & Keogh River, BC & 129 & $\begin{array}{l}\text { Logging, nutrient treatments, } \\
\text { hatchery steelhead rearing, } \\
\text { commercial harvest }\end{array}$ & $\mathrm{R}, \mathrm{SN}$ & NL & $\begin{array}{l}1977- \\
1986\end{array}$ & (Irvine et al. 1989) \\
\hline 49.14 & Chilliwack River, BC & 1230 & $\begin{array}{l}\text { Logging, floodplain habitat } \\
\text { restoration }\end{array}$ & $\mathrm{R}, \mathrm{SN}$ & NL & 2006 & $\begin{array}{l}\text { (Rosenfeld et al. } \\
\text { 2008) }\end{array}$ \\
\hline 48.90 & Carnation Creek, BC & 10 & Timber harvest & $\mathrm{R}, \mathrm{SN}$ & NL & $\begin{array}{l}1972- \\
1980\end{array}$ & $\begin{array}{l}\text { (Tschaplinski and } \\
\text { Hartman 1983) }\end{array}$ \\
\hline 48.17 & East Twin River, WA & 35 & Timber harvest, restoration & $\mathrm{R}$ & $\mathrm{SC}$ & $\begin{array}{l}2004 \\
2005\end{array}$ & (Bennett et al. 2011) \\
\hline 48.17 & $\begin{array}{l}\text { East Twin and West } \\
\text { Twin Rivers, WA }\end{array}$ & 35,33 & Timber harvest, restoration & $\mathrm{R}$ & $\mathrm{SC}$ & $\begin{array}{l}2005- \\
2008\end{array}$ & (Roni et al. 2012) \\
\hline 48.05 & $\begin{array}{l}\text { Skagit, Stillaguamish, } \\
\text { Quillayute, and Hoh } \\
\text { River, WA }\end{array}$ & 2774 & $\begin{array}{l}\text { Wilderness recreation, timber } \\
\text { harvest, agriculture, rural residential }\end{array}$ & $\mathrm{R}$ & $\mathrm{SC}$ & $\begin{array}{l}1987- \\
2000\end{array}$ & (Roni et al. 2006) \\
\hline 47.66 & Big Beef Creek, WA & 38 & $\begin{array}{l}\text { Timber harvest, fishway at upper } \\
\text { watershed lake, wetlands, streams }\end{array}$ & $\mathrm{R}$ & $\mathrm{SC}$ & $\begin{array}{l}1990, \\
1991\end{array}$ & $\begin{array}{l}\text { (Quinn and Peterson } \\
\text { 1996) }\end{array}$ \\
\hline 47.50 & Cedar River, WA & 487 & Dam, fish ladder, habitat restoration & $\mathrm{R}$ & $\mathrm{SC}$ & $\begin{array}{l}2006- \\
2008\end{array}$ & (Pess et al. 2011) \\
\hline
\end{tabular}




\begin{tabular}{|c|c|c|c|c|c|c|c|}
\hline $\begin{array}{l}\text { Latitude } \\
\left({ }^{\circ} \mathrm{N}\right)\end{array}$ & Basin name & $\begin{array}{l}\text { Basin area } \\
\left(\mathrm{km}^{2}\right)\end{array}$ & Land use & $\begin{array}{l}\text { Precip } \\
\text { type }\end{array}$ & $\begin{array}{l}\text { Pop. } \\
\text { status }\end{array}$ & $\begin{array}{l}\text { Study } \\
\text { years }\end{array}$ & Reference \\
\hline 46.33 & Grays River, WA & 321 & $\begin{array}{l}\text { Dyking and development of wetlands } \\
\text { and estuary habitat; timber harvest, } \\
\text { coho hatchery }\end{array}$ & $\mathrm{R}$ & $\mathrm{Th}$ & $\begin{array}{l}2008- \\
2010\end{array}$ & (Craig et al. 2014) \\
\hline 45.05 & Salmon River, OR & 195 & $\begin{array}{l}\text { Agriculture, grazing, water } \\
\text { diversion, tidal channel and marsh } \\
\text { restoration }\end{array}$ & $\mathrm{R}$ & $\mathrm{Th}$ & $\begin{array}{l}2008- \\
2011\end{array}$ & (Jones et al. 2014) \\
\hline 43.92 & $\begin{array}{l}\text { West Fork Smith } \\
\text { River, OR }\end{array}$ & 69 & Timber harvest, roads, splash dams & $\mathrm{R}$ & Th & 2002 & $\begin{array}{l}\text { (Ebersole et al. } \\
\text { 2006a) }\end{array}$ \\
\hline 43.81 & $\begin{array}{l}\text { West Fork Smith } \\
\text { River, OR }\end{array}$ & 69 & Timber harvest, roads, splash dams & $\mathrm{R}$ & Th & $\begin{array}{l}2003- \\
2005\end{array}$ & $\begin{array}{l}\text { (Ebersole et al. } \\
\text { 2009) }\end{array}$ \\
\hline 43.32 & South Slough, OR & 78 & NA & $\mathrm{R}$ & $\mathrm{Th}$ & $\begin{array}{l}1999 \\
2000\end{array}$ & $\begin{array}{l}\text { (Miller and Sadro } \\
\text { 2003) }\end{array}$ \\
\hline 40.79 & Freshwater Creek, CA & 92 & $\begin{array}{l}\text { Timber harvest, agriculture, } \\
\text { residential land use, restored tidal } \\
\text { marshland }\end{array}$ & $\mathrm{R}$ & $\mathrm{Th}$ & $\begin{array}{l}2010- \\
2012\end{array}$ & $\begin{array}{l}\text { (Rebenack et al. } \\
\text { 2015) }\end{array}$ \\
\hline
\end{tabular}


Table 3.3. Potential drivers of movement and/or growth patterns considered per study. $X$ 's equate to yes and blank cells equate to no, studies organized north to south based on basin mouth latitude, as in Table $3.2(n=18)$.

\begin{tabular}{|c|c|c|c|c|c|c|}
\hline $\begin{array}{l}\text { Climate } \\
\text {-Driven }\end{array}$ & Density & $\begin{array}{l}\text { In-stream } \\
\text { Habitat }\end{array}$ & Landscape & $\begin{array}{l}\text { Fish } \\
\text { Size }\end{array}$ & Productivity & Reference \\
\hline $\mathrm{X}$ & & & $\mathrm{X}$ & $\mathrm{X}$ & & $\begin{array}{l}\text { (Thedinga et al. } \\
\text { 1994b) }\end{array}$ \\
\hline \multirow[t]{4}{*}{$\mathrm{X}$} & & & & $X$ & & (Murphy et al. 1997) \\
\hline & & $\mathrm{X}$ & & $\mathrm{X}$ & & $\begin{array}{l}\text { (Bramblett et al. } \\
\text { 2002) }\end{array}$ \\
\hline & & $\mathrm{X}$ & & $\mathrm{X}$ & & $\begin{array}{l}\text { (Irvine and Ward } \\
\text { 1989) }\end{array}$ \\
\hline & & $\mathrm{X}$ & & $\mathrm{X}$ & $\mathrm{X}$ & $\begin{array}{l}\text { (Rosenfeld et al. } \\
\text { 2008) }\end{array}$ \\
\hline $\mathrm{X}$ & & & & $\mathrm{X}$ & & (Hartman et al. 1982) \\
\hline \multirow[t]{8}{*}{$\mathrm{X}$} & & $\mathrm{X}$ & $\mathrm{X}$ & & & $\begin{array}{l}\text { (Tschaplinski and } \\
\text { Hartman 1983b) }\end{array}$ \\
\hline & & & & $\mathrm{X}$ & & (Bennett et al. 2011) \\
\hline & $\mathrm{X}$ & $\mathrm{X}$ & $\mathrm{X}$ & $\mathrm{X}$ & & (Roni et al. 2012) \\
\hline & $\mathrm{X}$ & $\mathrm{X}$ & & $\mathrm{X}$ & & (Roni et al. 2006) \\
\hline & & $\mathrm{X}$ & $\mathrm{X}$ & $\mathrm{X}$ & & $\begin{array}{l}\text { (Quinn and Peterson } \\
\text { 1996) }\end{array}$ \\
\hline & $\mathrm{X}$ & $\mathrm{X}$ & $\mathrm{X}$ & $\mathrm{X}$ & & (Pess et al. 2011) \\
\hline & & $\mathrm{X}$ & & & & (Craig et al. 2014) \\
\hline & & $\mathrm{X}$ & $\mathrm{X}$ & $\mathrm{X}$ & & (Jones et al. 2014) \\
\hline $\mathrm{X}$ & $\mathrm{X}$ & $\mathrm{X}$ & $\mathrm{X}$ & $\mathrm{X}$ & $\mathrm{X}$ & $\begin{array}{l}\text { (Ebersole et al. } \\
\text { 2006a) }\end{array}$ \\
\hline $\mathrm{X}$ & & $\mathrm{X}$ & $\mathrm{X}$ & $\mathrm{X}$ & $\mathrm{X}$ & (Ebersole et al. 2009) \\
\hline$X$ & & $\mathrm{X}$ & $\mathrm{X}$ & $\mathrm{X}$ & & $\begin{array}{l}\text { (Miller and Sadro } \\
\text { 2003) }\end{array}$ \\
\hline $\mathrm{X}$ & & $\mathrm{X}$ & $\mathrm{X}$ & $\mathrm{X}$ & & $\begin{array}{l}\text { (Rebenack et al. } \\
\text { 2015) }\end{array}$ \\
\hline
\end{tabular}


Table 3.4. Rearing habitat types documented per movement study, with mean and standard deviation of noted unique juvenile life histories leading to smolt outmigration $(n=17)$.

\begin{tabular}{lcc}
\hline Rearing habitat type & Number of studies & $\begin{array}{c}\text { Mean number of movement strategies } \\
\text { ( } \pm \text { standard deviation) }\end{array}$ \\
\hline Estuary & 5 & $4(+/-0.5)$ \\
Main Channel & 5 & $2(+/-1.0)$ \\
Pond/Lake & 4 & $3(+/-1.0)$ \\
Tributary & 3 & $3(+/-0.5)$ \\
\hline
\end{tabular}


Figures

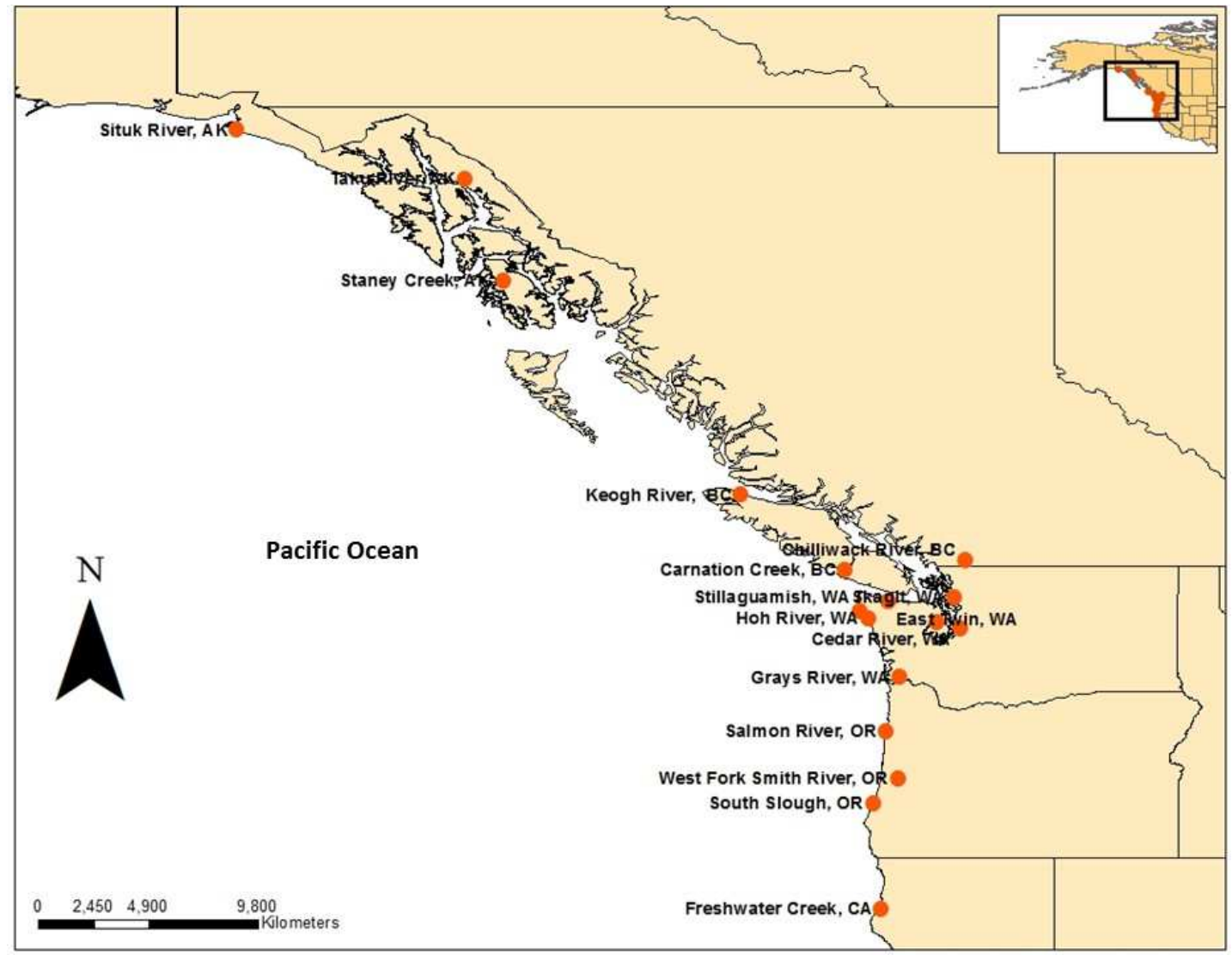

Figure 3.1. Basin mouth locations and names of the reviewed studies $(n=18)$. 


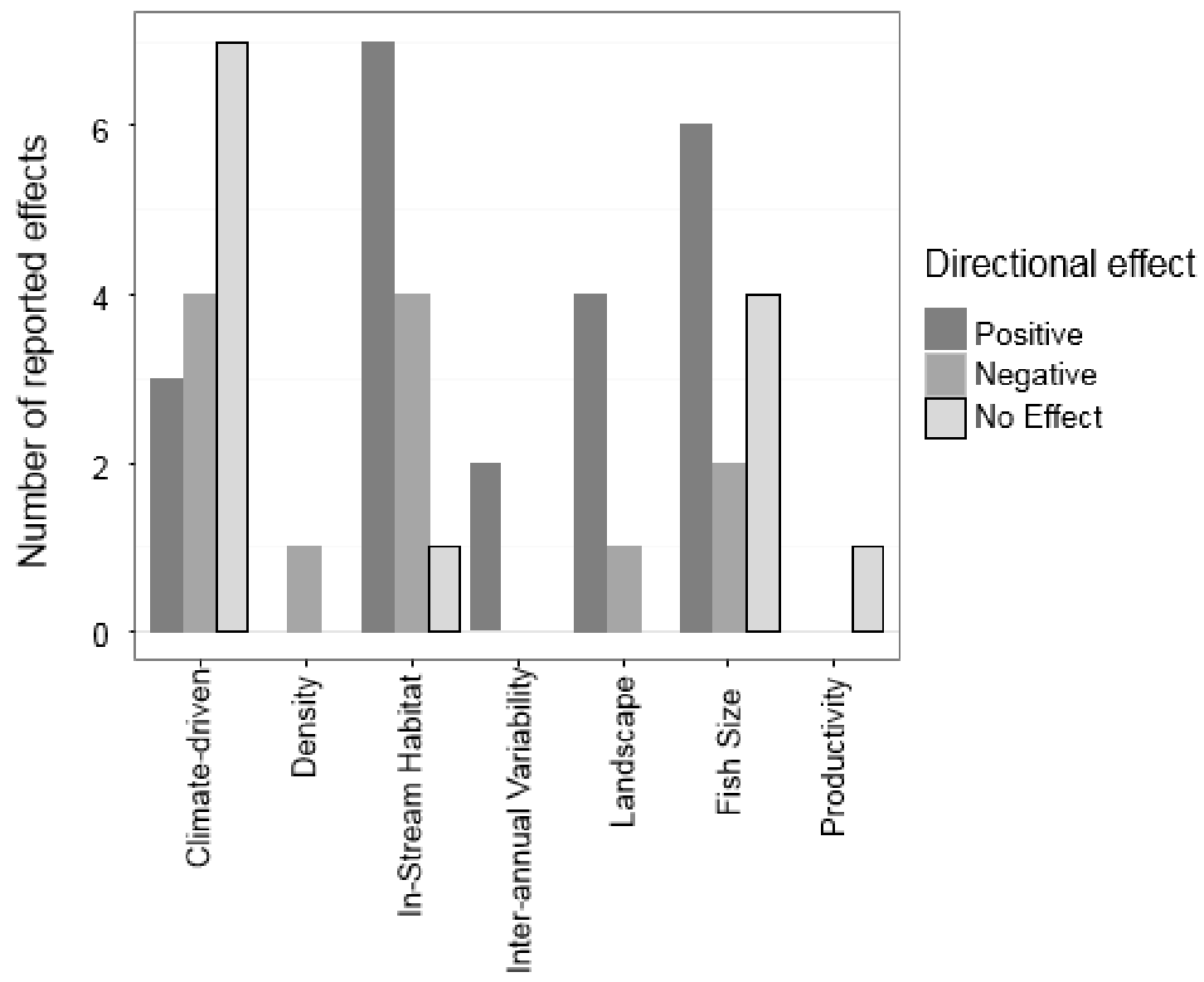

Figure 3.2. Directional effects noted across studies for environmental, fish size, and population effects on movement timing. Effect indicates a significant relationship from a reviewed study $(p<\mathbf{0 . 0 5})$. A positive effect on movement indicates that as a predictor variable increases in quantity or quality, it is associated with an increase in movement timing, or later (spring) season movement. A negative effect on movement indicates that as a predictor variable increases in quantity or quality, it is associated with a decrease in movement timing, or earlier (winter) seasonal movement $(\mathbf{n}=16)$. 


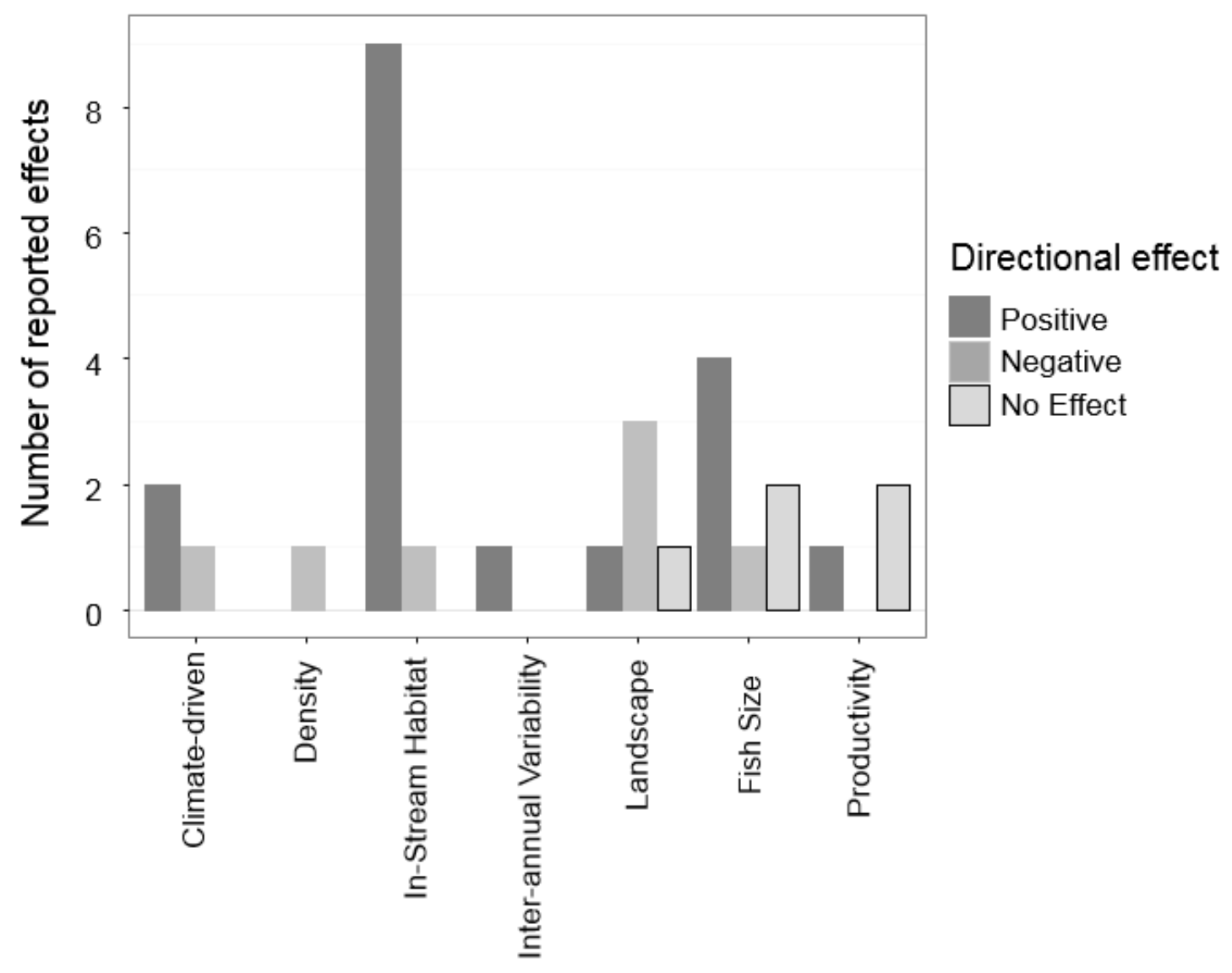

Figure 3.3. Directional effects noted across studies for environmental variables, fish size, and population effects on growth. Effect indicates a significant relationship from a reviewed study $(p<0.05)$. A positive effect on growth indicates that as a predictor variable increases in quantity or quality, it is associated with an increase in growth. A negative effect on growth indicates that as a predictor variable increases in quantity or quality, it is associated with a decrease in growth $(n=16)$. 


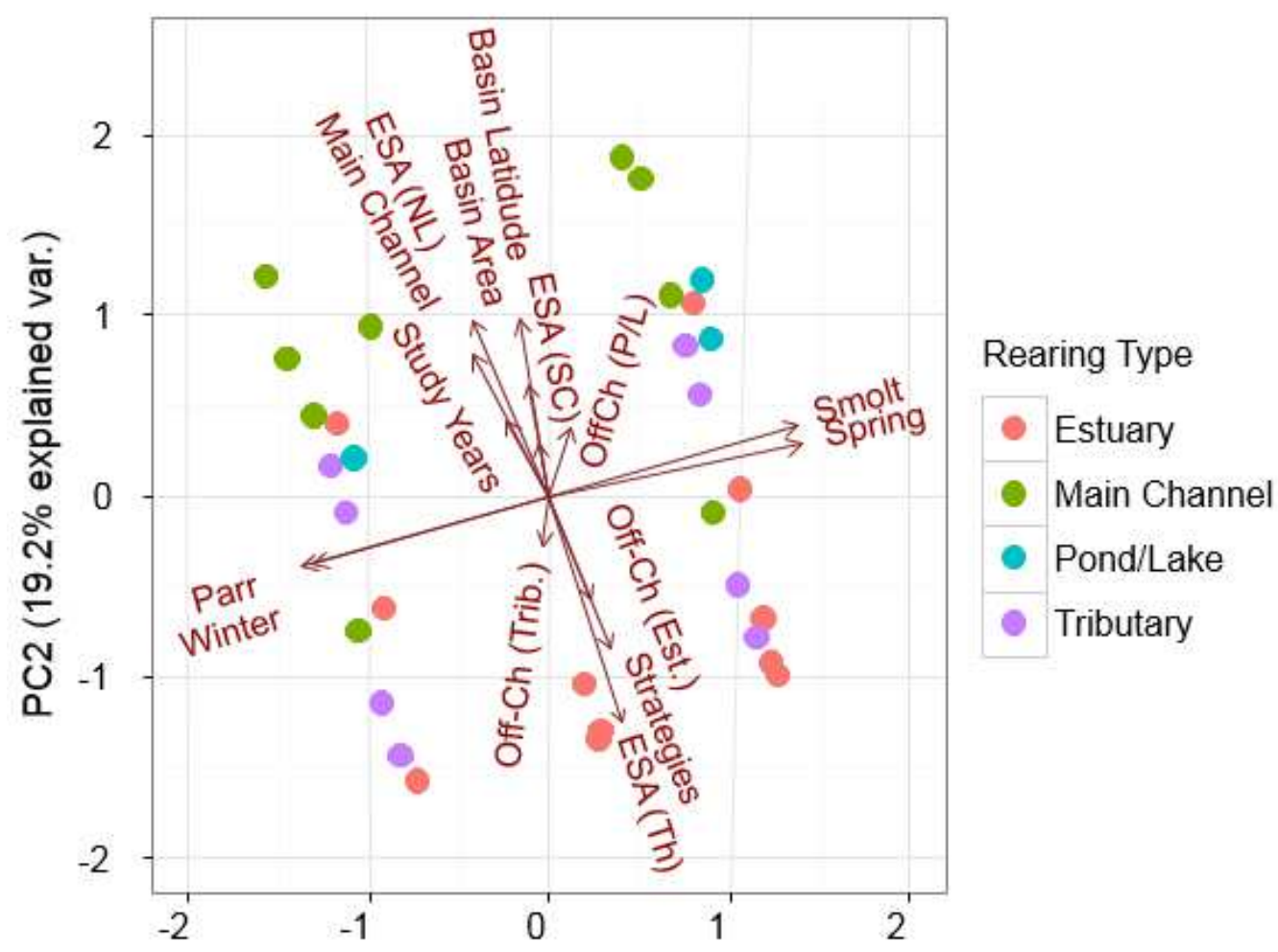

PC1 (24.2\% explained var.)

Figure 3.4. Standardized PCA results for habitat effect on movement strategy $(n=$ 16). Studies are grouped by non-main channel rearing habitat type (main channel when no non-main channel rearing identified). Shortened vector names are Off-Ch $=$ Off-Channel habitat, ESA $=$ Endangered Species Act listing, $\mathbf{N L}=$ ESA Not Listed, $\mathbf{S C}=$ ESA Species of Concern, $\mathbf{T h}=$ ESA Threatened, Strategies $=$ number of unique movement strategies per study, Main Channel = Main-channel rearing, Trib $=$ tributary-rearing, $P / L=$ pond or lake rearing. 


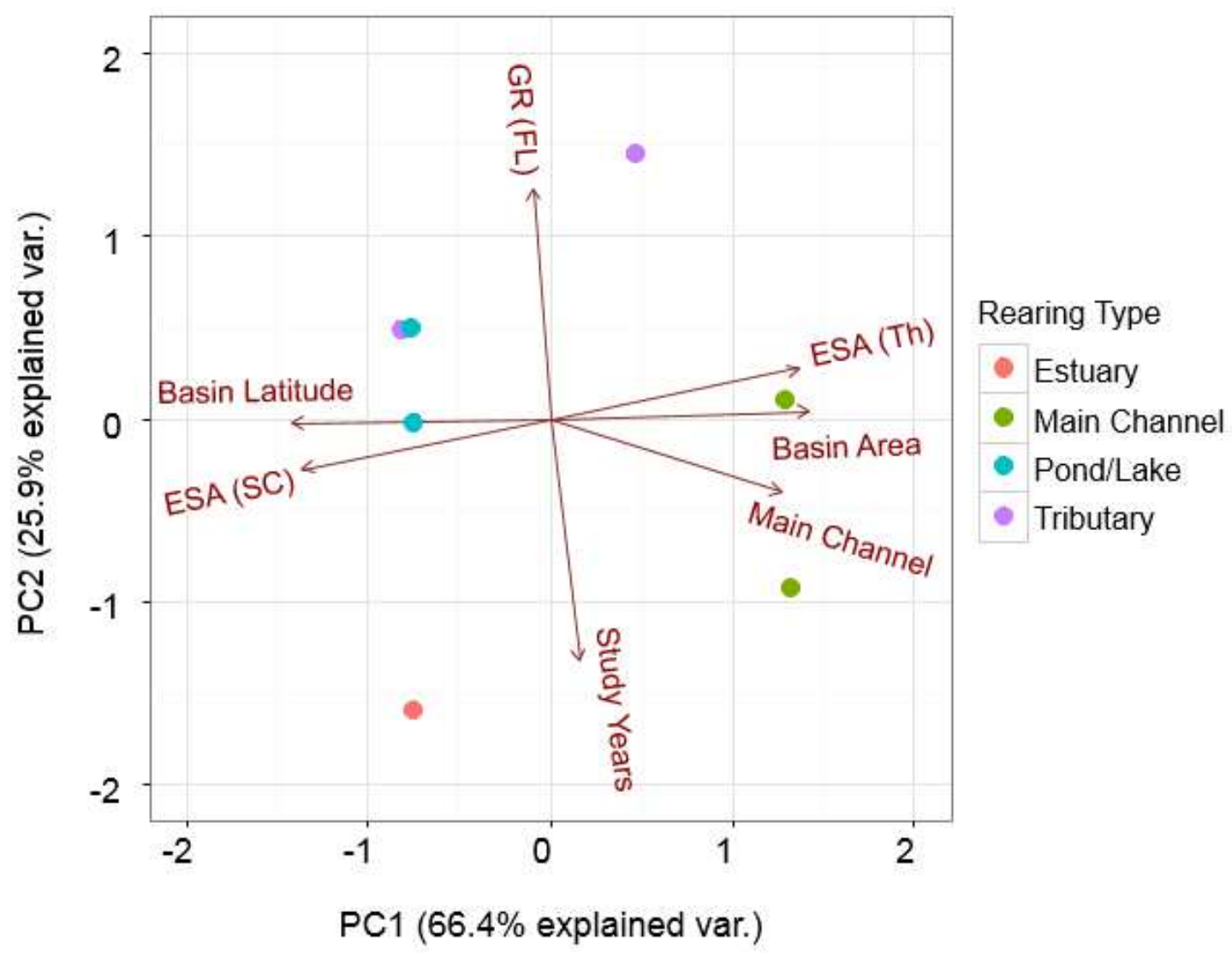

Figure 3.5. Standardized PCA results for initial fish fork length statistical effect on growth $(n=8)$. Studies are grouped by non-main channel rearing habitat type (main channel when no non-main channel rearing identified). Shortened vector names are ESA = Endangered Species Act listing, SC $=$ ESA Species of Concern, Th $=$ ESA Threatened, Main Channel $=$ Main-channel rearing, $\mathbf{G R}=$ Growth rate, $F L=$ fish fork length. 


\section{Chapter 4 : Conclusions}

Coho salmon depend upon freshwater rearing for one to two years prior to smolt outmigration to the ocean. During this extensive juvenile rearing period, fish must navigate dynamic watershed conditions, including winter flooding, which can both reconnect high quality rearing habitat that provides ample shelter and foraging opportunities, as well as decrease the quality of main channel habitat due to high velocity storm conditions. I examined fish-habitat relationships through an observational study of hatchery-released coho salmon movement in a southern, drought-stricken watershed as well as through a literature review of movement and growth studies on coho salmon in watersheds across their North American range.

Diversity in movement behavior is evident across the entire range of coho salmon, including more vulnerable populations experiencing extreme drought conditions. The observational portion (Chapter 2) identified three unique movement strategies that increase distribution of fish temporally (winter downstream movement versus spring downstream movement) as well as spatially (inter-stream movement and lower and upper stream segregation). This variability was observed despite limited freshwater rearing for these hatchery-released fish as well as drought conditions limiting habitat connectivity. Continual support of movement diversity must therefore consider watershed conditions as well as habitat interactions with precipitation and thermal regimes, which are expected to increase in intensity with climate change. Restoring and conserving non-main channel habitat, such as wetlands and low-gradient stream habitats, may aid in supporting juvenile movement diversity. This is based on the importance of these watershed features as well 
as the association of off-channel rearing habitat types with fish behavior in both the observational study (Chapter 2) and literature review, which also considered the role of small tributaries and estuarine habitats (Chapter 3). Furthermore, quality of in-stream habitat may also be important, especially when off-channel habitat is limited. This is evident in the delayed movement timing from Mill Creek despite limited off-channel features (Chapter 2) as well as the importance of tributary streams when ponds, lakes, and estuaries were not used or available by fish in studies included in my review (Chapter 3).

Growth pattern analyses suggest that two factors are at play: how big a fish is prior to the winter and the growth potential of its winter rearing habitat. Although little variability in fish size existed in the fish that comprised my sample from the Russian River, evidence from the literature supports the importance of winter growth on spring smolt size (Quinn and Peterson 1996, Ebersole et al. 2006). Growth potential can shift seasonally as well, due to thermal conditions, stream velocity, and dynamics of prey availability among different habitat types across watersheds (Satterthwaite et al. 2012). It is therefore essential to provide connectivity across watersheds, allowing fish to utilize inter-stream movement and downstream movement during the winter season. These movement strategies may be alternatives to the bet hedging strategy of remaining within stocking or rearing habitat during the winter season. Winter movement may increase growth capabilities, by allowing fish to grow more than in their stocking or summer rearing location, although at the risk of greater predation during movement and reduced growth from increased swimming energetic costs or limited foraging in newly found habitats. However, if individuals that move survive, this behavior could increase 
population stability by increasing the spatial and temporal template on which the population functions.

Seasonal and inter-annual shifts in fish behavior emphasize the importance of quantifying fish-habitat interactions beyond single seasons and study years. Multiple reviewed studies observed inter-annual variability in fish size and growth and movement patterns, suggesting that long-term monitoring is essential to long-term recovery goals. Mapping utilized habitats and their association with growth across multiple years could help prioritize watershed conservation strategies, by preserving and restoring habitats associated with unique, life history patterns. My observational study in the Russian River took place during an extreme drought in California, and therefore may provide a portrait of future conditions across the range of coho salmon. Based on this study, I suggest that management strategies should continue to focus on providing low-velocity winter refuges, since infrequent, but high intensity precipitation events, such as the ones during the 2014 - 2015 winter, may become the new normal. Initial fish movement was associated with these rain events, including upstream inter-stream movement, suggesting fish are actively searching for higher quality habitat during winter flood events. Not all streams necessarily need to provide the same habitat types though, because juvenile fish are capable of extensive migrations across stream networks. Additionally, streams that provide unique habitats may increase population stability by allowing fish to distribute themselves across watersheds rather than all fish responding to the same environmental conditions within a specific stream. 
Pacific salmon recovery efforts are often supported by freshwater restoration projects, which may be lacking in terms of addressing the large temporal and spatial scales of population patterns and watershed processes (Bernhardt and Palmer 2011, Naiman et al. 2012). Long-term persistence of salmon populations is often dependent on the ability of a population to withstand disturbances, which can improve when greater phenotypic diversity is present (Watters et al. 2003, Schindler et al. 2010). Diversity in the timing of movement could increase population persistence by spatially and temporally distributing rearing and outmigration timing by juvenile fish. This is evident even in endangered populations, with significantly different movement times across different streams despite similar fish sizes. Improving juvenile salmon resilience to changing conditions may increase when diverse stream systems and connections are supported through conservation and restoration efforts. Not all streams necessarily need to provide low gradient, floodplain-rearing habitat for coho salmon, but connections to streams, lakes, and estuaries that do provide these benefits can allow fish to move and potentially grow more than in lower quality winter rearing areas. Movement behavior is even evident in hatchery-reared populations, further supporting the importance of understanding habitat impacts on fish, and the important role these early movers have in shaping decision making. This study provides evidence that low gradient and productive stream habitats supporting delayed movement timing, and high gradient habitats supporting earlier movement timing. Future work could evaluate relocation habitat types and conditions as well as habitat differences between streams for the inter-stream detected fish group. These additional considerations could help address the population 
benefits of early movement strategies, since other work has documented spawning success by these individuals, but not necessarily where they are rearing after leaving study streams (Jones et al. 2014, Bennett et al. 2014). 


\section{References}

Achord, S., Sandford, Benjamin, P., Smith, Steven, G., Wassard, W.R., and Prentice, E.F. 2011. In-stream monitoring of PIT-tagged wild spring/summer Chinook salmon juveniles in Valley Creek, Idaho. Am. Fish. Soc. Symp. 76: 1-14.

Allan, J.D. 2004. Landscapes and riverscapes: the influence of land use on stream ecosystems. Annu. Rev. Ecol. Evol. Syst. 35(1): 257-284. doi:10.1146/annurev.ecolsys.35.120202.110122.

Anderson, J.H., Kiffney, P.M., Pess, G.R., and Quinn, T.P. 2008. Summer distribution and growth of juvenile coho salmon during colonization of newly accessible habitat. Trans. Am. Fish. Soc. 137(3): 772-781. doi:10.1577/T07-013.1.

Andrew, M.E., and Wulder, M. a. 2011. Idiosyncratic responses of Pacific salmon species to land cover, fragmentation, and scale. Ecography (Cop.). 34(5): 780-797. doi:10.1111/j.1600-0587.2010.06607.x.

Araki, H., and Schmid, C. 2010. Is hatchery stocking a help or harm? Evidence, limitations and future directions in ecological and genetic surveys. Aquaculture 308: 2-11. Elsevier B.V. doi:10.1016/j.aquaculture.2010.05.036.

Armstrong, J.B., and Schindler, D.E. 2013. Going with the flow: Spatial distribution of juvenile coho salmon track an annually shifting mosaic of water temperature. Ecosystems 16(8): 1429-1441. doi:10.1007/s10021-013-9693-9.

Baxter, C. V., Fausch, K.D., and Saunders, C.W. 2005. Tangled webs: Reciprocal flows of invertebrate prey link streams and riparian zones. Freshw. Biol. 50(2): 201-220. doi:10.1111/j.1365-2427.2004.01328.x.

Beacham, T.D., Beamish, R.J., Candy, J.R., Wallace, C., Tucker, S., Moss, J.H., and Trudel, M. 2014. Stock-specific size of juvenile sockeye salmon in British Columbia waters and in the Gulf of Alaska. Trans. Am. Fish. Soc. (March 2015): 37-41. doi:10.1080/00028487.2014.889751.

Beechie, T., Buhle, E., Ruckelshaus, M., Fullerton, A., and Holsinger, L. 2006. Hydrologic regime and the conservation of salmon life history diversity. Biol. Conserv. 130(4): 560-572. doi:10.1016/j.biocon.2006.01.019.

Bellmore, J.R., Baxter, C. V., Martens, K., and Connolly, P.J. 2013. The floodplain food web mosaic: a study of its importance to salmon and steelhead with implications for their recovery. Ecol. Appl. 23(1): 189-207.

Benda, L., Poff, N.L., Miller, D., Dunne, T., Reeves, G., Pess, G., Pollock, M., Poff, L.N., Miller, D., Dunne, T., Reeves, G., Pess, G., and Pollock, M. 2004. The network dynamics hypothesis: how channel networks structure riverine habitats. Bioscience 54(5): 413-427. doi:10.1641/00063568(2004)054[0413:TNDHHC]2.0.CO;2. 
Bennett, T.R., Roni, P., Denton, K., McHenry, M., and Moses, R. 2014. Nomads no more: Early juvenile coho salmon migrants contribute to the adult return. Ecol. Freshw. Fish (Reimers 1971): 1-12. doi:10.1111/eff.12144.

Bennett, T.R., Wissmar, R.C., and Roni, P. 2011. Fall and spring emigration timing of juvenile coho salmon from East Twin River, Washington. Northwest Sci. 85(4): $562-570$.

Bentley, K.T., and Schindler, D.E. 2013. Body condition correlates with instantaneous growth in stream-dwelling rainbow trout and Arctic grayling. Trans. Am. Fish. Soc. 142: 747-755. doi:10.1080/00028487.2013.769899.

Bentley, K.T., Schindler, D.E., Armstrong, J.B., Cline, T.J., and Brooks, G.T. 2015. Inter-tributary movements by resident salmonids across a boreal riverscape. PLoS One 10(9): e0136985. doi:10.1371/journal.pone.0136985.

Bernhardt, E.S., and Palmer, M. a. 2011. River restoration: the fuzzy logic of repairing reaches to reverse catchment scale degradation. Ecol. Appl. 21(6): 1926-1931. doi:10.1890/10-1574.1.

Beven, K.J., and Kirkby, M.J. 1979. A physically based, variable contributing area model of basin hydrology. Hydrol. Sci. Bull. 24(1): 43-69. doi:10.1080/02626667909491834.

Beyer, H.L. 2012. Geospatial modelling environment (version 0.7.3.0). Available from http://www.spatialecology.com/gme.

Bisson, P.A., Dunham, J.B., and Reeves, G.H. 2009. Freshwater ecosystems and resilience of Pacific salmon: Habitat management based on natural variability. Ecol. Soc. 14(1).

Bisson, P.A., Nielsen, J.L., Palmason, R.A., and Grove, L.E. 1982. A system of naming habitat types in small streams, with examples of habitat utilization by salmonids during low stream flow. In Acquisition and utilization of aquatic habitat inventory information. Edited by N.B. Armantrout. Western Division, American Fisheries Society, Bethesda, Maryland, USA. pp. 62-73.

Bottom, D.L., Jones, K.K., Cornwell, T.J., Gray, A., and Simenstad, C.A. 2005. Patterns of Chinook salmon migration and residency in the Salmon River estuary (Oregon). Estuar. Coast. Shelf Sci. 64(1): 79-93. doi:10.1016/j.ecss.2005.02.008.

Bramblett, R.G., Bryant, M.D., Wright, B.E., and White, R.G. 2002. Seasonal use of small tributary and main-stem habitats by juvenile steelhead, coho salmon, and Dolly Varden in a southeastern Alaska drainage basin. Trans. Am. Fish. Soc. 131: 498-506. doi:10.1577/1548-8659(2002)131<0498:SUOSTA>2.0.CO;2.

Breiman, L. 2001. Random forests. Mach. Learn.: 5-32. doi:10.1023/A:1010933404324.

Brown, L.R., Moyle, P.B., and Yoshiyama, R. 1994. Historical decline and current status 
of coho salmon in California. North. Am. J. Fish. Manag. 14(2): 237-261.

Bustard, D.R., and Narver, D.W. 1975. Aspects of the winter ecology of juvenile coho salmon (Oncorhynchus kisutch) and steelhead trout (Salmo gairdneri). J. Fish. Res. Board Canada 32(5): 667-680.

Carlson, S.M., Satterthwaite, W.H., and Fleming, I.A. 2011. Weakened portfolio effect in a collapsed salmon population complex. Can. J. Fish. Aquat. Sci. 68(9): 1579-1589. doi:10.1139/f2011-084.

Carter, J.L., and Resh, V.H. 2001. After site selection and before data analysis: Sampling, sorting, and laboratory procedures used in stream benthic macroinvertebrate monitoring programs by USA state agencies. J. North Am. Benthol. Soc. 20(4): $658-682$.

Craig, B.E., Simenstad, C.A., and Bottom, D.L. 2014. Rearing in natural and recovering tidal wetlands enhances growth and life-history diversity of Columbia Estuary tributary coho salmon Oncorhynchus kisutch population. J. Fish Biol. 85(1): 31-51. doi:10.1111/jfb.12433.

Cutler, D.R., Edwards, T.C., Beard, K.H., Cutler, A., Hess, K.T., Gibson, J., and Lawler, J.J. 2007. Random forests for classification in ecology. Ecology 88(11): 2783-2792. doi:10.1890/07-0539.1.

Dionne, M., and Dodson, J.J. 2002. Impact of exposure to a simulated predator (Mergus merganser) on the activity of juvenile Atlantic salmon (Salmo salar) in a natural environment. Can. J. Zool. Can. Zool. 80(11): 2006-2013. doi:Doi 10.1139/Z02176.

Doak, D.F., Bigger, D., Harding, E.K., Marvier, M.A., O’Malley, R.E., and Thomson, D. 1998. The statistical inevitability of stability-diversity relationships in community ecology. Am. Nat. 151(3): 264-276. doi:10.1086/286117.

Dodson, J.J., Aubin-Horth, N., Thériault, V., and Páez, D.J. 2013. The evolutionary ecology of alternative migratory tactics in salmonid fishes. Biol. Rev. 88(3): 602625. doi:10.1111/brv.12019.

Dudgeon, D., Arthington, A.H., Gessner, M.O., Kawabata, Z.-I., Knowler, D.J., Lévêque, C., Naiman, R.J., Prieur-Richard, A.-H., Soto, D., Stiassny, M.L.J., and Sullivan, C.A. 2006. Freshwater biodiversity: importance, threats, status and conservation challenges. Biol. Rev. 81: 163-182. doi:10.1017/S1464793105006950.

Ebersole, J.L., Colvin, M.E., Wigington, P.J., Leibowitz, S.G., Baker, J.P., Church, M.R., Compton, J.E., and Cairns, M.A. 2009a. Hierarchical modeling of late-summer weight and summer abundance of juvenile coho salmon across a stream network. Trans. Am. Fish. Soc. 138(5): 1138-1156. doi:10.1577/T07-245.1.

Ebersole, J.L., Colvin, M.E., Wigington, P.J., Leibowitz, S.G., Baker, J.P., Church, M.R., 
Compton, J.E., Miller, B.A., Cairns, M.A., Hansen, B.P., and La Vigne, H.R. 2009 b. Modeling stream network-scale variation in coho salmon overwinter survival and smolt size. Trans. Am. Fish. Soc. 138(3): 564-580. doi:10.1577/T08-047.1.

Ebersole, J.L., Wigington, P.J., Baker, J.P., Cairns, M.A., and Church, M.R. 2006. Juvenile coho salmon growth and survival across stream network seasonal habitats. Trans. Am. Fish. Soc. 135: 1681-1697.

Emmett, R., Llansó, R., Newton, J., Thom, R., Hornberger, M., Morgan, C., Levings, C., Copping, A., Fishman, P., and Llanso, R. 2000. Geographic signatures of North American west coast estuaries. Estuaries 23(6): 765. doi:10.2307/1352998.

ESRI. 2013. ArcGIS 10.2.

Fausch, K.D. 1984. Profitable stream position for salmonids: relating specific growth rate to net energy gain. Can. J. Zool. 62(3): 441-451.

Fausch, K.D., Torgersen, C.E., Baxter, C. V., and Hiram, L.W. 2002. Landscapes to riverscapes: Bridging the gap between research and conservation of stream fishes. Bioscience 52(6): 483-498.

FISHPRO. 2004. Hatchery and genetic management plans for Russian River fish production facilities: coho salmon and steelhead. Portland, Oregon.

Flitcroft, R., Burnett, K., Snyder, J., Reeves, G., and Ganio, L. 2014. Riverscape patterns among years of juvenile coho salmon in midcoastal Oregon: implications for conservation. Trans. Am. Fish. Soc. 143(1): 26-38.

doi:10.1080/00028487.2013.824923.

Flosi, G., Downie, S., Hopelain, J., Bird, M., Coey, R., and Collins, B. 2010. California salmonid stream habitat restoration manual. In 4th edition. California Department of Fish and Game.

Fraser, D.J. 2008. How well can captive breeding programs conserve biodiversity? A review of salmonids. Evol. Appl. 1(4): 535-86. doi:10.1111/j.17524571.2008.00036.x.

Freshwater, C., Trudel, M., Beacham, T.D., Godbout, L., Neville, C.M., Tucker, S., and Juanes, F. 2016. Disentangling individual- and population-scale processes within a latitudinal size gradient in sockeye salmon. Can. J. Fish. Aquat. Sci. 73: 1-12.

Frissell, C.A., Liss, W.J., Warren, C.E., and Hurley, M.D. 1986. A hierarchical framework for stream habitat classification: viewing streams in a watershed context. Environ. Manage. 10: 199-214.

Gibbons, J.W., and Andrews, K.M. 2004. PIT tagging: simple technology at its best. Bioscience 54(5): 447. doi:10.1641/0006-3568(2004)054[0447:PTSTAI]2.0.CO;2.

Gibson, C.A., Meyer, J.L., Poff, N.L., Hay, L.E., and Georgakakos, A. 2005. Flow 
regime alterations under changing climate in two river basins: implications for freshwater ecosystems. River Res. Appl. 21(8): 849-864. doi:10.1002/rra.855.

Greene, C.M., Hall, J.E., Guilbault, K.R., and Quinn, T.P. 2010. Improved viability of populations with diverse life-history portfolios. Biol. Lett. 6: 382-386.

Groot, C., Margolis, L., and Clarke, W.C. (Editors). 1995. Physiological ecology of Pacific salmon. University of British Columbia Press, Vancouver, British Columbia.

Gustafson, R.G., Waples, R.S., Myers, J.M., Weitkamp, L.A., Bryant, G.J., Johnson, O.W., and Hard, J.J. 2007. Pacific salmon extinctions: Quantifying lost and remaining diversity. Conserv. Biol. 21(4): 1009-1020. doi:10.1111/j.15231739.2007.00693.x.

Hansen, M.J., Boisclair, D., Brandt, S.B., Hewett, S.W., Kitchell, J.F., Lucas, M.C., and Ney, J.J. 1993. Applications of bioenergetic models to fish ecology and management: Where do we go from here? Trans. Am. Fish. Soc. 122: 1019-1030.

Hartman, G.F., Anderson, B.C., and Scrivener, J.C. 1982. Seaward movement of coho salmon (Oncorhynchus kisutch) fry in Carnation Creek, an unstable coastal stream in British Columbia. Can. J. Fish. Aquat. Sci. 39(4): 588-597.

Hayes, S. a., Bond, M.H., Hanson, C. V., Freund, E. V., Smith, J.J., Anderson, E.C., Ammann, A.J., and MacFarlane, R.B. 2008. Steelhead growth in a small central California watershed: upstream and estuarine rearing patterns. Trans. Am. Fish. Soc. 137: 114-128. doi:10.1577/T07-043.1.

Healey, M.C. 2009. Resilient salmon, resilient fisheries for British Columbia, Canada. Ecol. Soc. 14(1).

Hicks, B.J., Wipfli, M.S., Lang, D.W., and Lang, M.E. 2005. Marine-derived nitrogen and carbon in freshwater-riparian food webs of the Copper River Delta, southcentral Alaska. Oecologia 144(4): 558-69. doi:10.1007/s00442-005-0035-2.

Hilborn, R., Quinn, T.P., Schindler, D.E., and Rogers, D.E. 2003. Biocomplexity and fisheries sustainability. Proc. Natl. Acad. Sci. U. S. A. 100(11): 6564-6568. doi:10.1073/pnas. 1037274100 .

Holtby, L.B., Andersen, B.C., and Kadowaki, R.K. 1990. Importance of smolt size and early ocean growth to interannual variability in marine survival of coho salmon (Oncorhynchus kisutch). Can. J. Fish. Aquat. Sci. 47(11): 2181-2194. doi:10.1139/f90-243 LA - English.

Jenness, J. 2006. Topographic Position Index extension for ArcView 3.x, v. 1.3a. Jenness Enterprises. Available from http://www.jennessent.com/arcview/tpi.htm.

Jones, K.K., Cornwell, T.J., Bottom, D.L., Campbell, L.A., and Stein, S. 2014. The contribution of estuary-resident life histories to the return of adult Oncorhynchus kisutch. J. Fish Biol. 85(1): 52-80. doi:10.1111/jfb.12380. 
Koski, K. V. 2009. The fate of coho salmon nomads: the story of an estuarine-rearing strategy promoting resilience. Ecol. Soc. 14(1): 1-15.

McClure, M.M., Carlson, S.M., Beechie, T.J., Pess, G.R., Jorgensen, J.C., Sogard, S.M., Sultan, S.E., Holzer, D.M., Travis, J., Sanderson, B.L., Power, M.E., and Carmichael, R.W. 2008. Evolutionary consequences of habitat loss for Pacific anadromous salmonids. Evol. Appl. 1(2): 300-318. doi:10.1111/j.17524571.2008.00030.x.

Meyer, J.L., Sale, M.J., Mulholland, P.J., and Poff, N.L. 1999. Impacts of climate change on aquatic ecosystem functioning and health. doi:10.1111/j.17521688.1999.tb04222.x.

Miller, B.A., and Sadro, S. 2003. Residence time and seasonal movements of juvenile coho salmon in the ecotone and lower estuary of Winchester Creek, South Slough, Oregon. Trans. Am. Fish. Soc. 132: 546-559. doi:10.1577/1548$8659(2003) 132<0546$.

Montgomery, D.R. 1999. Process domains and the river continuum. J. Am. Water Resour. Assoc. 35(2): 397-410.

Montgomery, D.R., and Buffington, J.M. 1997. Channel-reach morphology in mountain drainage basins. Bull. Geol. Soc. Am. 109(5): 596-611. doi:10.1130/00167606(1997)109<0596:CRMIMD>2.3.CO.

Moore, J.W., McClure, M., Rogers, L.A., and Schindler, D.E. 2010. Synchronization and portfolio performance of threatened salmon. Conserv. Lett. 3(5): 340-348. doi:10.1111/j.1755-263X.2010.00119.x.

Morita, K., and Nagasawa, T. 2010. Latitudinal variation in the growth and maturation of masu salmon (Oncorhynchus masou) parr. Can. J. Fish. Aquat. Sci. 67: 955-965.

Naiman, R.J., Alldredge, J.R., Beauchamp, D.A., Bisson, P.A., Congleton, J., Henny, C.J., Huntly, N., Lamberson, R., Levings, C., Merrill, E.N., Pearcy, W.G., Rieman, B.E., Ruggerone, G.T., Scarnecchia, D., Smouse, P.E., and Wood, C.C. 2012. Developing a broader scientific foundation for river restoration: Columbia River food webs. Proc. Natl. Acad. Sci. U. S. A. 109(52): 21201-7. doi:10.1073/pnas.1213408109.

Naiman, R.J., Bilby, R.E., Schindler, D.E., and Helfield, J.M. 2002. Pacific Salmon, nutrients, and the dynamics of freshwater and riparian ecosystems. Ecosystems 5(4): 0399-0417. doi:10.1007/s10021-001-0083-3.

National Marine Fisheries Service. 2008. Biological Opinion. La Jolla, CA.

National Marine Fisheries Service. 2012. Final Recovery Plan for Central California Coast coho salmon Evolutionary Significant Unit. Santa Rosa, California, California. 
National Research Council. 1996. Upstream: Salmon and society in the Pacific Northwest.

Nehlsen, W., Williams, J.E., and Lichatowich, J.A. 1991. Pacific salmon at the crossroads: Stocks at risk from California, Oregon, Idaho, and Washington. Fisheries 16(2): 4-21.

Nickelson, T.E., Rodgers, J.D., Johnson, S.L., and Solazzi, M.F. 1992. Seasonal changes in habitat use by juvenile coho salmon (Oncorhynchus kisutch) in Oregon coastal streams. Can. J. Fish. Aquat. Sci. 49(4): 783-789.

Nielsen, J.L. 1992. Microhabitat-specific foraging behavior, diet, and growth of juvenile coho salmon. Trans. Am. Fish. Soc. 121(5): 617-634.

Ogston, L., Gidora, S., Foy, M., and Rosenfeld, J. 2015. Watershed-scale effectiveness of floodplain habitat restoration for juvenile coho salmon in the Chilliwack River, British Columbia. Can. J. Fish. Aquat. Sci. 72: 479-490. doi:10.1139/cjfas-20140189.

Olsson, I.C., Greenberg, L.A., Bergman, E., and Wysujack, K. 2006. Environmentally induced migration: the importance of food. Ecol. Lett. 9(6): 645-651.

doi:10.1111/j.1461-0248.2006.00909.x.

Opperman, J.J., Lohse, K.A., Brooks, C., Kelly, M.N., and Merenlender, A.M. 2005. Influence of land use on fine sediment in salmonid spawning gravels within the Russian River Basin, California. Can. J. Fish. Aquat. Sci. 62(12): 2740-2751. doi:10.1139/f05-187.

Pess, G.R., Kiffney, P.M., Liermann, M.C., Bennett, T.R., Anderson, J.H., and Quinn, T.P. 2011. The influences of body size, habitat quality, and competition on the movement and survival of juvenile coho salmon during the early stages of stream recolonization. Trans. Am. Fish. Soc. 140(4): 883-897.

doi:10.1080/00028487.2011.587752.

Pess, G.R., Montgomery, D.R., Steel, E.A., Bilby, R.E., and Feist, B.E. 2002. Landscape characteristics, land use, and coho salmon (Oncorhynchus kisutch) abundance, Snohomish River, Washington, USA. Can. J. Fish. Aquat. Sci. 59: 613. doi: 10.1139/f02-035.

Peterson, N.P. 1982. Population characteristics of juvenile coho salmon (Oncorhynchus kisutch) overwintering in riverine ponds. Can. J. Fish. Aquat. Sci. 39: 1303-1307.

Pierce, D.W., Cayan, D.R., Das, T., Maurer, E.P., Miller, N.L., Bao, Y., Kanamitsu, M., Yoshimura, K., Snyder, M.A., Sloan, L.C., Franco, G., and Tyree, M. 2013a. The key role of heavy precipitation events in climate model disagreements of future annual precipitation changes in california. J. Clim. 26(16): 5879-5896.

doi:10.1175/JCLI-D-12-00766.1. 
Pierce, D.W., Das, T., Cayan, D.R., Maurer, E.P., Miller, N.L., Bao, Y., Kanamitsu, M., Yoshimura, K., Snyder, M. a., Sloan, L.C., Franco, G., and Tyree, M. 2013 b.

Probabilistic estimates of future changes in California temperature and precipitation using statistical and dynamical downscaling. Clim. Dyn. 40(3-4): 839-856.

doi:10.1007/s00382-012-1337-9.

Poff, N.L., and Zimmerman, J.H. 2010. Ecological responses to altered flow regimes: a literature review to inform the science and management of environmental flows. Freshw. Biol. 55(1): 194-205. doi:10.1111/j.1365-2427.2009.02272.x.

Price, K. 2011. Effects of watershed topography, soils, land use, and climate on baseflow hydrology in humid regions: a review. Prog. Phys. Geogr. 35(4): 465-492. doi:10.1177/0309133311402714.

PRISM Climate Group. 2004. PRISM Climate Group. Available from http://prism.oregonstate.edu [accessed 19 February 2016].

Quinn, T.P. 2005. The behavior and ecology of Pacific salmon and trout. University of Washington Press, Seattle, WA.

Quinn, T.P., and Peterson, N.P. 1996. The influence of habitat complexity and fish size on over-winter survival and growth of individually marked juvenile coho salmon (Oncorhynchus kisutch) in Big Beef Creek, Washington. Can. J. Fish. Aquat. Sci. 53(7): 1555-1564. NRC Research Press Ottawa, Canada. doi:10.1139/f96-092.

R Core Team. 2015. R: A language and environment for statistical computing. R Foundation for Statistical Computing, Vienna, Austria. Available from https://www.r-project.org/.

Rebenack, J.J., Ricker, S., Anderson, C., Wallace, M., and Ward, D.M. 2015. Early emigration of juvenile coho salmon: implications for population monitoring. Trans. Am. Fish. Soc. 144: 163-172. doi:10.1080/00028487.2014.982258.

Reeves, G.H., Sleeper, J.D., and Lang, D.W. 2011. Seasonal changes in habitat availability and the distribution and abundance of salmonids along a stream gradient from headwaters to mouth in coastal Oregon. Trans. Am. Fish. Soc. 140(3): 537548. doi:10.1080/00028487.2011.572003.

Roni, P., Bennett, T., Holland, R., Pess, G., Hanson, K., Moses, R., McHenry, M., Ehinger, W., and Walter, J. 2012. Factors affecting migration timing, growth, and survival of juvenile coho salmon in two coastal Washington watersheds. Trans. Am. Fish. Soc. 141(4): 890-906. doi:10.1080/00028487.2012.675895.

Roni, P., Hanson, K., and Beechie, T. 2008. Global review of the physical and biological effectiveness of stream habitat rehabilitation techniques. North Am. J. Fish. Manag. 28(3): 856-890. doi:10.1577/M06-169.1.

Roni, P., and Quinn, T.P. 2001. Density and size of juvenile salmonids in response to 
placement of large woody debris in western Oregon and Washington streams. Can. J. Fish. Aquat. Sci. 58(2): 282-292. doi:10.1139/cjfas-58-2-282.

Rosenfeld, J.S., Leiter, T., Lindner, G., and Rothman, L. 2005. Food abundance and fish density alters habitat selection, growth, and habitat suitability curves for juvenile coho salmon (Oncorhynchus kisutch). Can. J. Fish. Aquat. Sci. 62(8): 1691-1701. doi:Doi 10.1139/F05-072.

Rosenfeld, J.S., and Raeburn, E. 2009. Effects of habitat and internal prey subsidies on juvenile coho salmon growth: Implications for stream productive capacity. Ecol. Freshw. Fish 18: 572-584. doi:10.1111/j.1600-0633.2009.00372.x.

Sandercock, F.K. 1991. Life history of coho salmon (Oncorhynchus kisutch). In Pacific salmon life histories. Edited by C. Groot and L. Margolis. University of British Columbia Press, Vancouver, British Columbia. p. 564.

Satterthwaite, W.H., Hayes, S.A., Merz, J.E., Sogard, S.M., Frechette, D.M., and Mangel, M. 2012. State-dependent migration timing and use of multiple habitat types in anadromous salmonids. Trans. Am. Fish. Soc. 141(3): 781-794. doi:10.1080/00028487.2012.675912.

Schindler, D.E., Hilborn, R., Chasco, B., Boatright, C.P., Quinn, T.P., Rogers, L.A., and Webster, M.S. 2010. Population diversity and the portfolio effect in an exploited species. Nature 465: 609-613.

Schlosser, I.J., and Angermeier, P.L. 1995. Spatial variation in demographic processes of lotic fishes: conceptual models, empirical evidence, and implications for conservation.

Shapovalov, L., and Taft, A.C. 1954. The life histories of the steelhead rainbow trout (Salmo gairdneri) and silver salmon (Oncorhynchus kisutch) with special reference to Waddell Creek, California and recommendations regarding their management. In California Department of Fish and Game Fish Bulletin. doi:10.1086/401331.

Sharma, R., and Hilborn, R. 2001. Empirical relationships between watershed characteristics and coho salmon (Oncorhynchus kisutch) smolt abundance in 14 western Washington streams. Can. J. Fish. Aquat. Sci. 58(7): 1453-1463. doi:10.1139/cjfas-58-7-1453.

Slatkin, M. 1974. Hedging one's evolutionary bets. Nature 250: 704-705.

Sloat, M.R., Fraser, D.J., Dunham, J.B., Falke, J.A., Jordan, C.E., McMillan, J.R., and Ohms, H.A. 2014. Ecological and evolutionary patterns of freshwater maturation in Pacific and Atlantic salmonines. Rev. Fish Biol. Fish. 24(3): 689-707. doi:10.1007/s11160-014-9344-z.

Sommer, T.R., Nobriga, M.L., Harrell, W.C., Batham, W., and Kimmerer, W.J. 2001. Floodplain rearing of juvenile Chinook salmon: evidence of enhanced growth and 
survival. Can. J. Fish. Aquat. Sci. 58(2): 325-333. doi:10.1139/cjfas-58-2-325.

Stanford, J.A., Lorang, M.S., and Hauer, F.R. 2005. The shifting habitat mosaic of river ecosystems. Travaux. Assoc. Int. Limnol. Theor. Appl. 29: 1-14.

Steiner Environmental Consulting. 1996. A history of the salmonid decline in the Russian River. Potter Valley, CA, CA.

Stewart, I.T., Cayan, D.R., and Dettinger, M.D. 2004. Changes in snowmelt runoff timing. Clim. Change 62: 217-232.

Strayer, D.L., and Dudgeon, D. 2010. Freshwater biodiversity conservation: recent progress and future challenges. J. North Am. Benthol. Soc. 29: 344-358. doi:10.1899/08-171.1.

Taylor, E.B. 1991. A review of local adaptation in Salmonidae, with particular reference to Pacific and Atlantic salmon. Aquaculture 98: 185-207. doi:10.1016/00448486(91)90383-i.

Thedinga, J.F., Murphy, M.L., Johnson, S.W., Lorenz, J.M., and Koski, K. V. 1994. Determination of salmonid smolt yield with rotary-screw traps in the Situk River, Alaska, to predict effects of glacial flooding. North Am. J. Fish. Manag. 14: 837851. doi:10.1577/1548-8675(1994)014<0837:DOSSYW>2.3.CO;2.

Tilman, D., Lehman, C.L., Bristow, C.E., Tilman, D., Lehman, C.L., and Bristow, C.E. 1998. Diversity-stability relationships: Statistical inevitability or ecological consequence? Am. Nat. 151(3): 277-282.

Tockner, K., Malard, F., and Ward, J.V. 2000. An extension of the flood pulse concept. Hydrol. Process. 14(16-17): 2861-2883. doi:10.1002/10991085(200011/12)14:16/173.0.CO;2-F.

Tschaplinski, P.J., and Hartman, G.F. 1983. Winter distribution of juvenile coho salmon (Oncorhynchus kisutch) before and after logging in Carnation Creek, British Columbia, and some implications for overwinter survival. Can. J. Fish. Aquat. Sci. 40(4): 452-461.

U.S. Geological Survey. 2000. USGS National Elevation Data.

U.S. Geological Survey. 2014. NLCD 2011 Land Cover (2011 Edition).

United States Environmental Protection Agency. 2009. National Water Quality Inventory: report to Congress. In U.S. EPA Office of Water. Washington, DC. doi:http://www.epa.gov/owow/305b/2004report/.

Walters, A.W., Copeland, T., and Venditti, D.A. 2013. The density dilemma: Limitations on juvenile production in threatened salmon populations. Ecol. Freshw. Fish 22: 508-519. doi:10.1111/eff.12046. 
Waples, R.S. 1991. Pacific salmon, Oncorynchus spp., and the definition of "species" under the Endangered Species Act. Mar. Fish. Rev. 53(3): 11-22.

Waples, R.S., Beechie, T., and Pess, G.R. 2009. Evolutionary history, habitat disturbance regime, and anthropogenic changes: What do these mean for resilience of Pacific salmon populations? Ecol. Soc. 14(1).

Waples, R.S., Gustafson, R.G., Weitkamp, L.A., Myers, J.M., Johnson, O.W., Busby, P.J., Hard, J.J., Bryant, G.J., Waknitz, F.W., Neely, K., Teel, D., Grant, W.S., Winans, G.A., Phelps, S., Marshall, A., and Baker, B.M. 2001. Characterizing diversity in salmon from the Pacific Northwest. J. Fish Biol. 59: 1-41. doi:10.1006/jfbi.2001.1764.

Waples, R.S., Pess, G.R., and Beechie, T.J. 2008. Evolutionary history of Pacific salmon in dynamic environments. Evol. Appl. 1(2): 189-206. doi:10.1111/j.17524571.2008.00023.x.

Ward, E.J., Pess, G.R., Anlauf-Dunn, K., Jordan, C.E., and Hilborn, R. 2012. Applying time series models with spatial correlation to identify the scale of variation in habitat metrics related to threatened coho salmon (Oncorhynchus kisutch) in the Pacific Northwest. Can. J. Fish. Aquat. Sci. 69(11): 1773-1782. doi:10.1139/f2012-096.

Watters, J.V., Lema, S.C., and Nevitt, G. a. 2003. Phenotype management: a new approach to habitat restoration. Biol. Conserv. 112: 435-445. doi:Doi: 10.1016/s0006-3207(02)00343-9.

Weatherley, A., and Rogers, S.C. 1978. Some aspects of age and growth. In Ecology of freshwater fish production. Edited by S.D. Gerking. John Wiley \& Sons, New York City, NY. pp. 52-74.

Weiss, A. 2001. Topographic position and landforms analysis. In Poster presentation, ESRI User Conference. ESRI User Conference, San Diego, California, California. doi:http://www.jennessent.com/downloads/TPI-poster-TNC_18x22.pdf.

Wigington, P.J., Ebersole, J.L., Colvin, M.E., Leibowitz, S.G., Miller, B., Hansen, B., Lavigne, H.R., White, D., Baker, J.P., Church, M.R., Brooks, J.R., Cairns, M.A., and Compton, J.E. 2006. Coho salmon dependence on intermittent streams. Front. Ecol. Environ. 4(10): 513-518.

Wilbur, H.M., and Rudolf, V.H.W. 2006. Life-History evolution in uncertain environments: bet hedging in time. Am. Nat. 168(3): 398-411. doi:10.1086/506258.

Wipfli, M.S., and Baxter, C. V. 2010. Linking ecosystems, food webs, and fish production: Subsidies in salmonid watersheds. Fisheries 35(8): 373-387. doi:10.1577/1548-8446-35.8.373.

Zimmerman, D.W. 2012. A note on consistency of non-parametric rank tests and related rank transformations. Br. J. Math. Stat. Psychol. 65(1): 122-144. 
doi:10.1111/j.2044-8317.2011.02017.x.

Zimmerman, D.W., and Zumbo, B.D. 1993. Rank transformations and the power of the student t-test and Welch t-test for nonnormal populations with unequal variances. Can. J. Exp. Psychol. Can. Psychol. Exp. 47(3): 523-539. doi:10.1037/h0078850.

Zimmerman, M.S., Kinsel, C., Beamer, E., Connor, E.J., and Pflug, D.E. 2015. Abundance, survival, and life history strategies of juvenile Chinook salmon in the Skagit River, Washington. Trans. Am. Fish. Soc. 144(3): 627-641. doi:10.1080/00028487.2015.1017658.

Zydlewski, G.B., Haro, A., Whalen, K.G., and McCormick, S.D. 2001. Performance of stationary and portable passive transponder detection systems for monitoring of fish movements. J. Fish Biol. 58(5): 1471-1475. doi:10.1111/j.10958649.2001.tb02302.x. 


\section{Appendix A: PIT antenna site design and detection metrics}

Table A1. PIT detection site description and sample size of PIT tagged individual fish. Number of detected fish is the total number of unique fish detected per detection site and release group size is the total number of PIT tagged individuals released per study stream. Some fish were detected at multiple detection sites per stream. Detection limitations mean partial to no detection capability at a site, due to equipment malfunctions.

\begin{tabular}{|c|c|c|c|c|c|c|}
\hline $\begin{array}{l}\text { Study } \\
\text { stream }\end{array}$ & Detection site & Array type & Detections limited & $\begin{array}{l}\text { Number } \\
\text { of fish } \\
\text { detected }\end{array}$ & $\begin{array}{l}\text { Distance to } \\
\text { stream } \\
\text { mouth }(\mathrm{m})\end{array}$ & $\begin{array}{l}\text { Release } \\
\text { group } \\
\text { size }\end{array}$ \\
\hline DUT & $\begin{array}{l}\text { Downstream } \\
\text { detection site }\end{array}$ & $\begin{array}{l}\text { Paired } \\
\text { antennas }\end{array}$ & N/A & 337 & 680 & 2830 \\
\hline \multirow[t]{2}{*}{ GRE } & $\begin{array}{l}\text { Downstream } \\
\text { detection site }\end{array}$ & $\begin{array}{l}\text { Paired } \\
\text { antennas }\end{array}$ & $\begin{array}{c}1 / 15 / 15-1 / 21 / 15 \\
5 / 5 / 15-6 / 4 / 15\end{array}$ & 411 & 6300 & 2778 \\
\hline & $\begin{array}{l}\text { Upstream } \\
\text { detection site }\end{array}$ & $\begin{array}{l}\text { Single } \\
\text { antenna }\end{array}$ & N/A & 983 & 9980 & \\
\hline \multirow[t]{2}{*}{ MIL } & $\begin{array}{l}\text { Downstream } \\
\text { detection site }\end{array}$ & $\begin{array}{l}\text { Paired } \\
\text { antennas }\end{array}$ & N/A & 702 & 2000 & 3724 \\
\hline & $\begin{array}{l}\text { Upstream } \\
\text { detection site }\end{array}$ & $\begin{array}{l}\text { Paired } \\
\text { antennas }\end{array}$ & $\begin{array}{c}2 / 5 / 15-2 / 9 / 15 \\
4 / 9 / 15-4 / 14 / 15\end{array}$ & 674 & 6100 & \\
\hline \multirow[t]{2}{*}{ WIL } & $\begin{array}{l}\text { Downstream } \\
\text { detection site }\end{array}$ & $\begin{array}{l}\text { Paired } \\
\text { antennas }\end{array}$ & $12 / 1 / 14-12 / 30 / 14$ & 49 & 410 & 2255 \\
\hline & $\begin{array}{l}\text { Upstream } \\
\text { detection site }\end{array}$ & $\begin{array}{l}\text { Paired } \\
\text { antennas }\end{array}$ & & 102 & 3700 & \\
\hline
\end{tabular}




\section{Appendix B: Landscape and in-stream habitat methods and data summaries}

Table B1. Shelter rating categories, based on California salmonid stream habitat restoration manual (Flosi et al. 2010). Shelter ratings were calculated by estimating the shelter rating value and then multiplying it by percent coverage, forming a shelter index on a scale from 0 to 500.

Shelter Rating: Pool shelter is the product of shelter complexity and percent shelter cover.

Shelter rating values are:

Value 1: Unit has no shelter

Value 2: Unit is lacking significant shelter and complexity. Unit has no LWD. Unit contains at least one of the following features in limited availability: SWD, Boulders, root masses, undercut bank, submerged vegetation, bubble curtain.

Value 3: Unit generally provides shelter, but lacks complexity, containing at least two of the following features in limited availability: LWD, SWD, Boulders, root masses, undercut bank, submerged vegetation, bubble curtain.

Value 4: Unit provides quality shelter from at least three of the following complex features: >1 LWD, > 2 SWD, undercut bank, large root mass, extensive aquatic vegetation/ submerged branches, $>4$ undercut boulders.

Value 5: Unit has excellent shelter with at least four complex shelter features (each available in extensive amounts). Unit must include $>2$ LWD and numerous SWD. Unit is difficult to navigate and survey.

In-stream Shelter Percent Cover: A measure of the area of the unit occupied by in-stream shelter as observed from an overhead view. 
Table B2. Landscape and in-stream variables used in predictive models to determine landscape influences on fish movement and growth patterns. Variables used in statistical analysis have their abbreviated, dataset name included in parentheses.

\begin{tabular}{|c|c|c|c|}
\hline Variable & Units & Source & Method \\
\hline \multicolumn{4}{|l|}{ Basin Characteristics } \\
\hline Stream lines & $\mathrm{m}$ & DEM derived & Calculated using ArcGIS Hydrology tool set \\
\hline Basin area & $\mathrm{m}^{2}$ & DEM derived & $\begin{array}{l}\text { Calculated using ArcGIS watershed delineation tool. Delineated as } \\
\text { upslope influence per PIT antenna site and stream mouth. }\end{array}$ \\
\hline Riparian buffers & $\mathrm{m}^{2}$ & DEM derived & $\begin{array}{l}\text { Calculated using ArcGIS buffer tool at } 30,60 \text {, and } 120 \text { meter extents } \\
\text { around the streamlines per basin. }\end{array}$ \\
\hline Stream name & categorical & $\begin{array}{l}\text { USGS Geographic } \\
\text { Names Information } \\
\text { System }\end{array}$ & Release stream for each hatchery release group. \\
\hline Basin name & categorical & $\begin{array}{l}\text { USGS Geographic } \\
\text { Names Information } \\
\text { System }\end{array}$ & $\begin{array}{l}\text { Release stream mouth, downstream detection site, or upstream } \\
\text { detection site. }\end{array}$ \\
\hline Stream length & $\mathrm{m}$ & DEM derived & Length of stream habitat calculated using ArcGIS Hydrology tool set. \\
\hline Drainage density & $\mathrm{m}$ & DEM derived & Stream length/basin area \\
\hline Relief ratio & $\mathrm{m}$ & DEM derived & Distance between minimum and maximum elevation point per basin. \\
\hline Distance to ocean & $\mathrm{m}$ & DEM derived & Length of each basin mouth to the ocean. \\
\hline Distance to stream mouth & $\mathrm{m}$ & DEM derived & Length of each basin mouth to the mouth of overall basin. \\
\hline Mean slope (MN Slope) & percent & DEM derived & Percent slope calculated from DEM layers in ArcGIS. \\
\hline Maximum near stream slope & percent & DEM derived & $\begin{array}{l}\text { Maximum percent slope calculated from DEM layers in ArcGIS per } \\
\text { basin streamline. Considered near-stream rather than stream because } \\
\text { of the } 10 \text {-meter scale accuracy of DEM layers. }\end{array}$ \\
\hline $\begin{array}{l}\text { Mean canopy coverage }(\mathrm{MN} \\
\mathrm{CC})\end{array}$ & percent & $\begin{array}{l}\text { National Land Cover } \\
\text { Database } 2011\end{array}$ & Mean canopy coverage calculated per basin and riparian buffer area. \\
\hline Mean impervious surface & percent & $\begin{array}{l}\text { National Land Cover } \\
\text { Database } 2011\end{array}$ & $\begin{array}{l}\text { Mean percent impervious surface calculated per basin and riparian } \\
\text { buffer area (Impervious). }\end{array}$ \\
\hline
\end{tabular}




\begin{tabular}{|c|c|c|c|}
\hline Variable & Units & Source & Method \\
\hline Land use type & percent & $\begin{array}{l}\text { National Land Cover } \\
\text { Database } 2011\end{array}$ & $\begin{array}{l}\text { Land cover classifications calculated per basin and riparian buffer area } \\
\text { (Dev. Open, Dev. Low, Dev. Med., Dev. High, Cultivated Crops, } \\
\text { Barren Land, Conifer Forest, Deciduous Forest, Mixed Forest, Shrub, } \\
\text { Herbaceous, Herbaceous Wetland, Wooded Wetland) }\end{array}$ \\
\hline $\begin{array}{l}\text { Topographic Wetness Index } \\
\text { (TWI), mean and standard } \\
\text { deviation (MN TWI, SD } \\
\text { TWI) }\end{array}$ & index & DEM derived & $\begin{array}{l}1-10 \text { scaled index representing soil moisture conditions }(1=\text { high } \\
\text { run-off potential, } 10=\text { high pooling potential) (Beven and Kirkby } \\
\text { 1979). }\end{array}$ \\
\hline $\begin{array}{l}\text { Slope Position classification } \\
\text { (SPC) }\end{array}$ & percent & DEM derived & $\begin{array}{l}\text { Basin-scale percent coverage per six classification of slope types } \\
\text { (Weiss 2001). Classifications are Valley, Lower Slope (lower), Flat } \\
\text { Slope (flat), Middle Slope (middle), Upper slope (Upper), and Ridge. }\end{array}$ \\
\hline \multicolumn{4}{|l|}{ In-Stream Habitat } \\
\hline $\begin{array}{l}\text { Macroinvertebrate abundance, } \\
\text { mean and standard deviation } \\
(\mathrm{MN} \text { BMI, SD BMI) }\end{array}$ & count & $\begin{array}{l}\text { field collected, laboratory } \\
\text { estimated }\end{array}$ & Mean benthic abundance per habitat basin. \\
\hline $\begin{array}{l}\text { Shelter rating: mean and } \\
\text { coefficient of variation (MN } \\
\text { Shelter, CV Shelter) }\end{array}$ & index & field measurement. & $\begin{array}{l}\text { Calculated using the California Fish and Wildlife salmonid habitat } \\
\text { protocol (Flosi et al. 2010). }\end{array}$ \\
\hline \multicolumn{4}{|l|}{ In-Stream Habitat } \\
\hline Wetted width, bankfull width, & proportion & field measurement & $\begin{array}{l}\text { Variation in mean habitat unit width measurements }(\mathrm{m}) \text { among each } \\
\text { study stream }(\mathrm{m}) \text {. }\end{array}$ \\
\hline $\begin{array}{l}\text { Coefficient of variation (CV } \\
\text { WW, CV BF, CV), Wetted } \\
\text { Width: bankfull width, } \\
\text { coefficient of variation (CV } \\
\text { WW:BF) }\end{array}$ & proportion & field measurement & $\begin{array}{l}\text { Variation in habitat unit ratio of mean bankfull width to mean wetted } \\
\text { width }(\mathrm{m}) \text {. }\end{array}$ \\
\hline
\end{tabular}


Table B3. Summary of basin characteristics for each study stream. DS=downstream, US=upstream.

\begin{tabular}{|c|c|c|c|c|c|}
\hline Study Stream & Basin type & $\begin{array}{l}\text { Basin area } \\
\left(\mathrm{km}^{2}\right)\end{array}$ & $\begin{array}{l}\text { Stream } \\
\text { length }(\mathbf{k m})\end{array}$ & $\begin{array}{l}\text { Basin Mouth: distance to } \\
\text { Ocean }(\mathbf{k m})\end{array}$ & $\begin{array}{l}\text { Basin Mouth: distance to } \\
\text { stream mouth }(\mathrm{km})\end{array}$ \\
\hline \multirow{2}{*}{ DUT } & DS Basin & 30.6 & 41.9 & 17.3 & 0.68 \\
\hline & Entire Basin & 30.9 & 42.7 & 16.6 & 0.00 \\
\hline \multirow{2}{*}{ GRE } & DS Basin & 87.1 & 119.2 & 43.6 & 6.30 \\
\hline & US Basin & 25.7 & 36.0 & 47.2 & 9.98 \\
\hline \multirow{3}{*}{ MIL } & DS Basin & 56.7 & 77.3 & 55.1 & 2.00 \\
\hline & Entire Basin & 57.1 & 79.2 & 53.1 & 0.00 \\
\hline & US Basin & 29.8 & 38.9 & 59.2 & 6.10 \\
\hline WIL & DS Basin & 22.1 & 32.0 & 4.76 & 0.41 \\
\hline
\end{tabular}


Table B4. Summary of geomorphology data for study basins $(n=11)$. MN = mean, $\mathrm{SD}=$ standard deviation, $\mathrm{TWI}=$ Topographic Wetness Index, DS=downstream, US=upstream. Valley, Low Slope, Flat Slope, Middle Slope, Upper Slope, and Ridge are percent coverage classifications.

\begin{tabular}{|c|c|c|c|c|c|c|c|c|c|c|c|c|}
\hline $\begin{array}{l}\text { Study } \\
\text { Stream }\end{array}$ & Basin type & $\begin{array}{l}\text { Drainage } \\
\text { Density }\end{array}$ & $\begin{array}{l}\text { Relief } \\
\text { Ratio }\end{array}$ & $\begin{array}{l}\text { MN \% } \\
\text { Slope }\end{array}$ & Valley & $\begin{array}{l}\text { Low } \\
\text { Slope }\end{array}$ & $\begin{array}{l}\text { Flat } \\
\text { Slope }\end{array}$ & $\begin{array}{l}\text { Middle } \\
\text { Slope }\end{array}$ & $\begin{array}{l}\text { Upper } \\
\text { Slope }\end{array}$ & Ridge & $\begin{array}{l}\text { MN } \\
\text { TWI }\end{array}$ & $\begin{array}{l}\text { SD } \\
\text { of } \\
\text { TWI } \\
\end{array}$ \\
\hline \multirow{2}{*}{ DUT } & DS Basin & 0.00137 & 0.213 & 32.102 & 43.9 & 1.39 & 0.31 & 2.54 & 1.50 & 50.3 & 2.34 & 0.526 \\
\hline & Entire Basin & 0.00138 & 0.119 & 32.126 & 44.0 & 1.40 & 0.31 & 2.54 & 1.50 & 50.2 & 2.34 & 0.527 \\
\hline \multirow{3}{*}{ GRE } & DS Basin & 0.00137 & 0.050 & 14.436 & 39.6 & 4.97 & 6.14 & 3.19 & 3.91 & 42.2 & 2.65 & 0.578 \\
\hline & Entire Basin & 0.00139 & 0.045 & 16.681 & 41.0 & 4.53 & 5.49 & 3.03 & 3.58 & 42.4 & 2.61 & 0.593 \\
\hline & US Basin & 0.00140 & 0.043 & 21.360 & 41.7 & 2.23 & 1.41 & 2.94 & 2.25 & 49.5 & 2.51 & 0.573 \\
\hline \multirow{3}{*}{ MIL } & DS Basin & 0.00136 & 0.061 & 38.047 & 46.9 & 1.12 & 0.03 & 2.27 & 1.13 & 48.5 & 2.24 & 0.535 \\
\hline & Entire Basin & 0.00139 & 0.056 & 37.793 & 46.8 & 1.18 & 0.27 & 2.27 & 1.26 & 48.2 & 2.25 & 0.543 \\
\hline & US Basin & 0.00130 & 0.076 & 40.771 & 47.2 & 1.04 & 0.01 & 2.14 & 1.03 & 48.6 & 2.23 & 0.524 \\
\hline \multirow{3}{*}{ WIL } & DS Basin & 0.00145 & 0.061 & 30.895 & 47.9 & 1.47 & 0.11 & 2.77 & 1.42 & 46.4 & 2.38 & 0.547 \\
\hline & Entire Basin & 0.00152 & 0.061 & 30.875 & 47.9 & 1.47 & 0.11 & 2.77 & 1.42 & 46.3 & 2.39 & 0.548 \\
\hline & US Basin & 0.00145 & 0.091 & 31.551 & 46.9 & 1.50 & 0.12 & 2.74 & 1.37 & 47.4 & 2.37 & 0.523 \\
\hline
\end{tabular}


Table B5. Summary of in-stream data for study basins $(\mathrm{n}=11) . \mathrm{MN}=$ mean, $\mathrm{SD}=$ standard deviation, $\mathrm{BMI}=\mathbf{b e n t h i c}$ macroinvertebrate abundance, $\mathrm{CV}=$ coefficient of variation, $\mathrm{DS}=$ downstream, $\mathrm{US}=$ upstream.

\begin{tabular}{lllllllll}
\hline $\begin{array}{l}\text { Study } \\
\text { Stream }\end{array}$ & Basin type & MN BMI & SD BMI & $\begin{array}{l}\text { MN shelter } \\
\text { rating }\end{array}$ & $\begin{array}{l}\text { CV, shelter } \\
\text { rating }\end{array}$ & $\begin{array}{l}\text { CV, Wetted } \\
\text { Width (m) }\end{array}$ & $\begin{array}{l}\text { CV, } \\
\text { Bankfull } \\
\text { Width (m) }\end{array}$ & $\begin{array}{l}\text { CV, Wetted } \\
\text { Width: Bankfull } \\
\text { Width }\end{array}$ \\
\hline \multirow{2}{*}{ DUT } & DS Basin & 1017 & 1164 & 35 & 1 & 2.8 & 3.0 & 3.0 \\
& Entire Basin & 849 & 1038 & 27 & 1 & 1.7 & 2.4 & 2.8 \\
\multirow{2}{*}{ GRE } & DS Basin & 3717 & 1528 & 7 & 1 & 6.5 & 5.9 & 5.1 \\
& Entire Basin & 2920 & 1892 & 19 & 1 & 3.1 & 2.1 & 3.3 \\
& US Basin & 3717 & 1528 & 7 & 1 & 6.5 & 5.9 & 5.1 \\
MIL & DS Basin & 633 & 454 & 51 & 2 & 5.4 & 4.2 & 11.5 \\
& Entire Basin & 834 & 579 & 45 & 1 & 3.8 & 2.1 & 1.9 \\
& US Basin & 538 & 372 & 52 & 2 & 6.3 & 4.5 & 3.2 \\
& DS Basin & 498 & 456 & 22 & 1 & 2.3 & 12.4 & 2.6 \\
& Entire Basin & 498 & 456 & 22 & 1 & 1.9 & 1.0 & 0.9 \\
& US Basin & 508 & 607 & 16 & 1 & 2.5 & 16.5 & 2.9 \\
\hline
\end{tabular}


Table B6. Summary of vegetation coverage for study basins. All values are percent coverage $(\mathrm{n}=11)$. $\mathrm{DS}=\mathrm{downstream}$, US= upstream.

\begin{tabular}{|c|c|c|c|c|c|c|c|c|c|c|}
\hline $\begin{array}{l}\text { Study } \\
\text { Stream }\end{array}$ & Basin type & $\begin{array}{l}\text { MN } \\
\text { Canopy }\end{array}$ & $\begin{array}{l}\text { Deciduous } \\
\text { forest }\end{array}$ & $\begin{array}{l}\text { Conifer } \\
\text { forest }\end{array}$ & $\begin{array}{l}\text { Mixed } \\
\text { forest }\end{array}$ & $\begin{array}{l}\text { Shrub/ } \\
\text { Scrub }\end{array}$ & Herbaceous & $\begin{array}{l}\text { Wooded } \\
\text { wetland }\end{array}$ & $\begin{array}{l}\text { Herbaceous } \\
\text { wetland }\end{array}$ & $\begin{array}{l}\text { Barren } \\
\text { surface }\end{array}$ \\
\hline \multirow{2}{*}{ DUT } & DS Basin & 60.4 & 0.5 & 67.0 & 3.0 & 13.0 & 10.4 & 0.227 & 0.000 & 0.000 \\
\hline & Entire Basin & 60.5 & 0.5 & 66.8 & 3.0 & 12.9 & 10.3 & 0.350 & 0.000 & 0.124 \\
\hline \multirow{3}{*}{ GRE } & DS Basin & 27.3 & 1.7 & 18.7 & 5.8 & 14.6 & 39.4 & 0.936 & 0.007 & 0.123 \\
\hline & Entire Basin & 30.7 & 2.1 & 22.5 & 6.1 & 13.8 & 36.1 & 0.846 & 0.006 & 0.098 \\
\hline & US Basin & 46.1 & 1.6 & 44.8 & 7.5 & 13.8 & 23.6 & 0.203 & 0.000 & 0.122 \\
\hline \multirow{3}{*}{ MIL } & DS Basin & 63.5 & 3.7 & 63.9 & 12.6 & 8.7 & 8.7 & 0.000 & 0.000 & 0.088 \\
\hline & Entire Basin & 63.1 & 3.7 & 63.4 & 12.6 & 8.7 & 8.7 & 0.000 & 0.000 & 0.000 \\
\hline & US Basin & 71.1 & 2.8 & 80.2 & 5.9 & 6.1 & 3.1 & 0.000 & 0.000 & 0.000 \\
\hline \multirow{3}{*}{ WIL } & DS Basin & 54.7 & 1.3 & 59.1 & 4.8 & 12.0 & 16.3 & 2.564 & 0.265 & 0.000 \\
\hline & Entire Basin & 54.7 & 1.3 & 59.0 & 4.8 & 12.0 & 16.2 & 2.569 & 0.289 & 0.000 \\
\hline & US Basin & 58.9 & 0.9 & 68.0 & 3.7 & 7.7 & 15.3 & 0.612 & 0.000 & 0.000 \\
\hline
\end{tabular}


Table B7. Summary agriculture and development for study basins. All values are percent coverage $(n=11)$. DS=downstream, US=upstream.

\begin{tabular}{|c|c|c|c|c|c|c|c|}
\hline $\begin{array}{l}\text { Study } \\
\text { Stream }\end{array}$ & Basin type & $\begin{array}{l}\text { MN } \\
\text { Impervious } \\
\text { surface }\end{array}$ & $\begin{array}{l}\text { Developed open } \\
\text { space }\end{array}$ & $\begin{array}{l}\text { Low } \\
\text { development } \\
\text { intensity }\end{array}$ & $\begin{array}{l}\text { Medium } \\
\text { development } \\
\text { intensity }\end{array}$ & $\begin{array}{l}\text { High } \\
\text { development } \\
\text { intensity }\end{array}$ & Cropland \\
\hline \multirow{2}{*}{ DUT } & DS Basin & 0.25 & 5.30 & 0.177 & 0.115 & 0.000 & 0.000 \\
\hline & Entire Basin & 0.30 & 5.59 & 0.242 & 0.117 & 0.000 & 0.000 \\
\hline \multirow{3}{*}{ GRE } & DS Basin & 2.08 & 10.66 & 2.029 & 0.761 & 0.154 & 5.071 \\
\hline & Entire Basin & 2.12 & 10.74 & 2.024 & 0.853 & 0.159 & 4.506 \\
\hline & US Basin & 0.41 & 6.90 & 0.035 & 0.028 & 0.000 & 1.314 \\
\hline \multirow{3}{*}{ MIL } & DS Basin & 0.07 & 2.37 & 0.011 & 0.000 & 0.000 & 0.000 \\
\hline & Entire Basin & 0.08 & 2.40 & 0.017 & 0.000 & 0.000 & 0.550 \\
\hline & US Basin & 0.03 & 1.99 & 0.000 & 0.000 & 0.000 & 0.000 \\
\hline \multirow{3}{*}{ WIL } & DS Basin & 0.12 & 3.66 & 0.020 & 0.000 & 0.000 & 0.000 \\
\hline & Entire Basin & 0.12 & 3.70 & 0.020 & 0.000 & 0.000 & 0.000 \\
\hline & US Basin & 0.09 & 3.77 & 0.000 & 0.000 & 0.000 & 0.000 \\
\hline
\end{tabular}




\section{Appendix C: PCA supporting data for Chapter 2 and Chapter 3 results}

Table C1. PCA loading values (eigenvectors) model with basin and riparian-scale variables from Chapter 2 watershed analysis. Includes basin and in-stream watershed characteristics $(n=11)$. Scale denoted in parentheses for predictor variables: Basin $=$ full basin-scale, $120=120-\mathrm{m}$ riparian scale, $60=60-\mathrm{m}$ riparian scale, $30=30-m$ riparian scale, stream $=$ near-stream scale $(10-m)$.

\begin{tabular}{lll}
\hline Predictor Variable & PC1 & PC2 \\
\hline Geomorphology & & \\
\hline Barren Land & 0.089 & -0.004 \\
Barren Land (120) & 0.085 & -0.014 \\
Drainage Density & -0.019 & 0.182 \\
Max. Slope (Stream) & -0.113 & -0.046 \\
Min. Slope (Stream) & -0.079 & -0.132 \\
MN Slope & -0.123 & -0.072 \\
MN Slope (120) & -0.118 & -0.090 \\
MN Slope (30) & -0.118 & -0.082 \\
MN Slope (60) & -0.117 & -0.091 \\
MN Slope (Stream) & -0.118 & 0.003 \\
MN TWI & 0.122 & 0.082 \\
Relief Ratio & -0.040 & 0.006 \\
SD TWI & 0.118 & 0.024 \\
SPC Flat Slope & 0.131 & 0.003 \\
SPC Low Slope & 0.131 & 0.024 \\
SPC Middle Slope & 0.102 & 0.131 \\
SPC Ridge & -0.100 & -0.067 \\
SPC Upper Slope & 0.132 & 0.023 \\
SPC Valley & -0.121 & 0.028 \\
\hline Vegetation & & \\
\hline Conifer Forest & -0.129 & -0.030 \\
Conifer Forest (120) & -0.129 & 0.025 \\
Conifer Forest (30) & -0.127 & 0.031 \\
Conifer Forest (60) & -0.128 & 0.031 \\
Conifer Forest (Stream) & -0.127 & 0.033 \\
Deciduous Forest & -0.005 & -0.167 \\
\hline Deciduous Forest (120) & 0.001 & -0.194 \\
Deciduous Forest (30) & 0.023 & -0.167 \\
Deciduous Forest (60) & 0.014 & -0.180 \\
Deciduous Forest (Stream) & 0.022 & -0.162 \\
Herbaceous & 0.125 & 0.063 \\
Herbaceous (120) & 0.131 & 0.016 \\
Herbaceous (30) & 0.130 & 0.007 \\
Herbaceous (60) & 0.130 & 0.016 \\
Herbaceous (Stream) & 0.130 & 0.006 \\
Herbaceous Wetland & -0.034 & 0.183 \\
Herbaceous Wetland (120) & -0.034 & 0.183 \\
Herbaceous Wetland (30) & -0.036 & 0.181 \\
Herbaceous Wetland (60) & -0.035 & 0.182 \\
& & \\
\hline
\end{tabular}




\begin{tabular}{|c|c|c|}
\hline Predictor Variable & PC1 & PC2 \\
\hline Herbaceous Wetland (Stream) & -0.036 & 0.180 \\
\hline Mixed Forest & -0.005 & -0.167 \\
\hline Mixed Forest (120) & 0.017 & -0.171 \\
\hline Mixed Forest (30) & 0.040 & -0.172 \\
\hline Mixed Forest (60) & 0.029 & -0.176 \\
\hline Mixed Forest (Stream) & 0.051 & -0.163 \\
\hline $\mathrm{MN}$ CC & -0.127 & -0.060 \\
\hline MN CC (120) & -0.131 & -0.027 \\
\hline MN CC (30) & -0.129 & -0.027 \\
\hline MN CC (60) & -0.129 & -0.030 \\
\hline MN CC (Stream) & -0.129 & -0.026 \\
\hline Shrub & 0.094 & 0.093 \\
\hline Shrub (120) & 0.118 & -0.047 \\
\hline Shrub (30) & 0.109 & -0.083 \\
\hline Shrub (60) & 0.111 & -0.081 \\
\hline Shrub (Stream) & 0.106 & -0.076 \\
\hline Wooded Wetland & 0.000 & 0.208 \\
\hline Wooded Wetland (120) & 0.002 & 0.209 \\
\hline Wooded Wetland (30) & 0.008 & 0.212 \\
\hline Wooded Wetland (60) & 0.003 & 0.211 \\
\hline Wooded Wetland (Stream) & 0.018 & 0.211 \\
\hline \multicolumn{3}{|l|}{ Development and Agriculture } \\
\hline Cultivated Crops & 0.130 & -0.006 \\
\hline Cultivated Crops (120) & 0.128 & -0.025 \\
\hline Cultivated Crops (30) & 0.126 & -0.032 \\
\hline Cultivated Crops (60) & 0.126 & -0.033 \\
\hline Cultivated Crops (Stream) & 0.123 & -0.039 \\
\hline Dev. High & 0.126 & 0.006 \\
\hline Dev. High (120) & 0.126 & 0.006 \\
\hline Dev. High (30) & 0.125 & 0.006 \\
\hline Dev. High (60) & 0.125 & 0.006 \\
\hline Dev. High (Stream) & 0.125 & 0.006 \\
\hline Dev. Low & 0.127 & 0.007 \\
\hline Dev. Low (120) & 0.119 & 0.011 \\
\hline Dev. Low (30) & 0.120 & 0.014 \\
\hline Dev. Low (60) & 0.113 & 0.015 \\
\hline Dev. Low (Stream) & 0.098 & 0.016 \\
\hline Dev. Med (120) & 0.124 & 0.006 \\
\hline Dev. Med (30) & 0.120 & 0.006 \\
\hline Dev. Med (60) & 0.121 & 0.006 \\
\hline Dev. Med (Stream) & 0.115 & 0.007 \\
\hline Dev. Medium & 0.127 & 0.005 \\
\hline Dev. Open & 0.129 & 0.037 \\
\hline Dev. Open (120) & 0.095 & -0.060 \\
\hline Dev. Open (30) & 0.064 & -0.159 \\
\hline Dev. Open (60) & 0.065 & -0.135 \\
\hline Dev. Open (Stream) & 0.073 & -0.144 \\
\hline Impervious & 0.130 & 0.008 \\
\hline Impervious (120) & 0.128 & 0.009 \\
\hline Impervious (30) & 0.128 & -0.018 \\
\hline Impervious (60) & 0.127 & -0.007 \\
\hline
\end{tabular}




\begin{tabular}{lll}
\hline Predictor Variable & PC1 & PC2 \\
Impervious (Stream) & 0.125 & -0.006 \\
\hline In-Stream Habitat & & \\
\hline CV BF & -0.029 & 0.079 \\
CV Shelter & -0.036 & -0.146 \\
CV WW & 0.038 & -0.134 \\
CV WW:BF & 0.012 & -0.135 \\
MN BMI & 0.117 & -0.020 \\
MN Shelter & -0.077 & -0.144 \\
SD BMI & 0.119 & -0.007 \\
\hline
\end{tabular}


Table C2. PCA loading values (eigenvectors) model with basin-scale variables only from Chapter 2 watershed analysis. Includes basin and in-stream watershed characteristics $(n=11)$.

\begin{tabular}{lll}
\hline Predictor Variable & PC1 & PC2 \\
\hline Geomorphology & & \\
\hline Barren Land & 0.1465 & 0.0297 \\
Drainage Density & 0.0003 & -0.3685 \\
MN Slope & -0.2212 & 0.0613 \\
MN TWI & 0.2215 & -0.0738 \\
Relief Ratio & -0.0691 & -0.0515 \\
SPC Flat Slope & 0.2193 & 0.0778 \\
SPC Low Slope & 0.2233 & 0.0403 \\
SPC Middle Slope & 0.1979 & -0.1767 \\
SPC Ridge & -0.1766 & 0.0405 \\
SPC Upper Slope & 0.2262 & 0.0378 \\
SPC Valley & -0.2007 & -0.1086 \\
\hline Vegetation & & \\
\hline Conifer Forest & -0.2216 & -0.0146 \\
Deciduous Forest & -0.0400 & 0.3008 \\
Herbaceous & 0.2228 & -0.0410 \\
Herbaceous Wetland & -0.0303 & -0.3216 \\
Mixed Forest & -0.0380 & 0.2710 \\
MN CC & -0.2245 & 0.0358 \\
Shrub & 0.1703 & -0.1344 \\
Wooded Wetland & 0.0323 & -0.3478 \\
\hline Development and Agriculture & & \\
\hline Cultivated Crops & 0.2173 & 0.0918 \\
Dev. High & 0.2090 & 0.0720 \\
Dev. Low & 0.2103 & 0.0677 \\
Dev. Medium & 0.2098 & 0.0665 \\
Dev. Open & 0.2227 & -0.0001 \\
Impervious & 0.2181 & 0.0647 \\
\hline In-Stream Habitat & & \\
\hline CV BF & -0.0234 & -0.1379 \\
CV Shelter & -0.0853 & 0.3141 \\
CV WW & 0.0476 & 0.3203 \\
CV WW:BF & 0.0010 & 0.2795 \\
MN BMI & 0.1988 & 0.1034 \\
MN Shelter & -0.1613 & 0.2217 \\
SD BMI & 0.1995 & 0.0534 \\
SD TWI & 0.2028 & 0.0190 \\
\hline & & \\
\hline
\end{tabular}


Table C3. PCA loading values (eigenvectors) model for Chapter 3 analysis of habitat effect on movement strategy across literature reviewed studies $(n=16)$. Shortened variable names are ESA = Endangered Species Act listing, Strategies $=$ number of unique movement strategies per study.

\begin{tabular}{lll}
\hline Variable & PC1 & PC2 \\
\hline Basin Latitude $\left({ }^{\circ} \mathrm{N}\right)$ & -0.0569 & 0.3821 \\
Basin Area $\left(\mathrm{km}^{2}\right)$ & -0.0237 & 0.1134 \\
Not Listed $(\mathrm{ESA})$ & -0.1488 & 0.3801 \\
Species of Concern (ESA) & -0.0413 & 0.2414 \\
Threatened (ESA) & 0.1402 & -0.4933 \\
Study Years & -0.0818 & 0.1642 \\
Strategies & 0.1166 & -0.3329 \\
Main Channel Rearing & -0.1470 & 0.3063 \\
Tributary Rearing & -0.0117 & -0.1076 \\
Estuary Rearing & 0.0803 & -0.2255 \\
Pond/Lake Rearing & 0.0393 & 0.1479 \\
Parr & -0.4781 & -0.1529 \\
Smolt & 0.4781 & 0.1529 \\
Spring & 0.4868 & 0.1112 \\
Winter & -0.4567 & -0.1484 \\
\hline
\end{tabular}


Table C4. PCA loading values (eigenvectors) model for Chapter 3 analysis of initial fish fork length statistical effect on growth across literature reviewed studies $(n=8)$. ESA = Endangered Species Act listing.

\begin{tabular}{lll}
\hline Variable & PC1 & PC2 \\
\hline Basin Latitude $\left({ }^{\circ} \mathrm{N}\right)$ & -0.4629 & -0.0106 \\
Basin Area $\left(\mathrm{km}^{2}\right)$ & 0.4631 & 0.0236 \\
Species of Concern $(\mathrm{ESA})$ & -0.4452 & -0.1442 \\
Threatened $(\mathrm{ESA})$ & 0.4452 & 0.1442 \\
Study Years & 0.0515 & -0.6930 \\
Main Channel Rearing & 0.4137 & -0.2104 \\
Initial fork length effect on growth rate & -0.0326 & 0.6582 \\
\hline
\end{tabular}




\section{Appendix D: Random forest model supporting data}

Table D1. Variable importance scores for all predictor variables in the three random forest models. Basin type included in parentheses after variable name for in-stream and landscape variables. Importance scores are mean decrease in model accuracy per variable per model, divided by the standard deviation among trees in mean decreasing model accuracy.

\begin{tabular}{lll}
\hline Predictor Variable & $\begin{array}{l}\text { Mean Decrease in Model } \\
\text { Accuracy (\%) }\end{array}$ & Variable Type \\
\hline Model: Upstream movement day & & Climate \\
\hline Temperature (US Basin) & 145.33 & Climate \\
Precipitation (US Basin) & 136.12 & Watershed \\
PC 2 (US Basin) & 64.11 & Watershed \\
PC 1 (US Basin) & 61.23 & Fish Size \\
Pre-winter relative FL & 10.50 & Fish Size \\
Pre-winter K & 9.03 & \\
\hline Model: Downstream movement day & & Fish Movement \\
\hline US Movement Day & 141.91 & Climate \\
Temperature (DS Basin) & 54.34 & Climate \\
Precipitation (DS Basin) & 45.78 & Climate \\
Temperature (US Basin) & 29.33 & Watershed \\
PC 2 (DS Basin) & 26.10 & Watershed \\
PC 2 (US Basin) & 25.87 & Watershed \\
PC 1 (US Basin) & 24.26 & Watershed \\
PC 1 (DS Basin) & 23.79 & Climate \\
Precipitation (US Basin) & 18.04 & Fish Size \\
Pre-winter relative FL & 11.89 & Fish Size \\
\hline Model: Growth rate & & Fish Size \\
\hline Pre-winter relative FL & 118.23 & Fish Size \\
Spring relative FL & 78.14 & Watershed \\
DS Movement Day & 32.07 & Watershed \\
PC 2 (DS Basin) & 29.19 & Fish Size \\
PC 1 (DS Basin) & 20.70 & Climate \\
Pre-winter K & 19.88 & \\
Temperature (DS Basin) & 5.73 & 3.38 \\
Precipitation (DS Basin) & & \\
\hline & & \\
\hline
\end{tabular}




\section{Appendix E: Directional classification supporting data}

Table E1. Influential factors analyzed for influence on pre-smolt outmigration and growth of coho salmon. Positive and negative relationships were statistically significant in the studies while non-relationships were not found to be statistically significant by the authors. Positive relationships were noted when an increase in factor quantity or quality corresponded with later timing of movement (spring movement) or greater growth rate and negative relationships were noted when an increase in factor quantity or quality corresponded with an earlier timing of movement (pre-spring movement) or lower growth rate. Inner-seasonal variations in relationships between factors and movement and growth responses were noted by multiple directional relationship symbols.

\begin{tabular}{|c|c|c|c|}
\hline $\begin{array}{l}\text { Unique pre-smolt and smolt movement } \\
\text { strategies }\end{array}$ & Influential movement factors $(+/-/ \not)$ & Influential growth factors $(+/-/ \neq)$ & Reference \\
\hline $\begin{array}{l}\text { Age- } 1 \text { smolts early in the summer and } \\
\text { then late in the summer ; age- } 2 \text { smolts } \\
\text { early in the summer }\end{array}$ & $\begin{array}{l}\text { Distance to ocean }(+) \text {, age }(+) \text {, fish } \\
\text { length }(+) \text {, distance to ocean*age }(-)\end{array}$ & N/A & $\begin{array}{l}\text { (Thedinga } \\
\text { et al. 1994) }\end{array}$ \\
\hline ( & $\begin{array}{l}\text { age }(-), \text { streamflow ( }+ \text { for age- } 0 \text { and } \\
\text { age- } 1, \neq \text { for age- } 2) \text {, size }(- \text { for age- } 0) \text {, } \\
\text { estuary rearing limited for age- } 0\end{array}$ & $\mathrm{~N} / \mathrm{A}$ & $\begin{array}{l}\text { (Murphy et } \\
\text { al. 1997) }\end{array}$ \\
\hline $\begin{array}{l}\text { movement into small-tributary habitat in } \\
\text { the spring and remaining until the } \\
\text { following fall; fall migrations between } \\
\text { small-tributary habitat and main-stream } \\
\text { habitat (occasionally multiple times } \\
\text { during the season), overwintering in } \\
\text { small-tributary habitat }\end{array}$ & small-tributary rearing $(+)$ & $\mathrm{N} / \mathrm{A}$ & $\begin{array}{l}\text { (Bramblett } \\
\text { et al. 2002) }\end{array}$ \\
\hline $\begin{array}{l}\text { Fall/winter age- } 0 \text {; age- } 1 \text { early spring - } \\
\text { summer; age- } 2 \text {, early spring }\end{array}$ & $\begin{array}{l}\text { Lake-rearing*age }(-), \text { stream- } \\
\text { rearing*age }(+) \text {, age }(+) \text {, growth }(-)\end{array}$ & Lake-rearing $(+)$, stream-rearing $(-)$ & $\begin{array}{l}\text { (Irvine et al } \\
\text { 1989) }\end{array}$ \\
\hline $\mathrm{N} / \mathrm{A}$ & $\begin{array}{l}\text { Stream-type rearing }(-) \text {, pond-type } \\
\text { rearing }(+) \text {, off-channel habitat area } \\
(+)\end{array}$ & $\begin{array}{l}\text { Stream-type rearing }(-) \text {, Pond-type rearing } \\
(+) \text {, density }(-)\end{array}$ & $\begin{array}{l}\text { (Rosenfeld } \\
\text { et al. 2008) }\end{array}$ \\
\hline Summer parr and winter parr & Streamflow $(+/ \neq)$, temperature $(-/ \neq)$ & N/A & $\begin{array}{l}\text { (Hartman et } \\
\text { al. 1982) }\end{array}$ \\
\hline
\end{tabular}




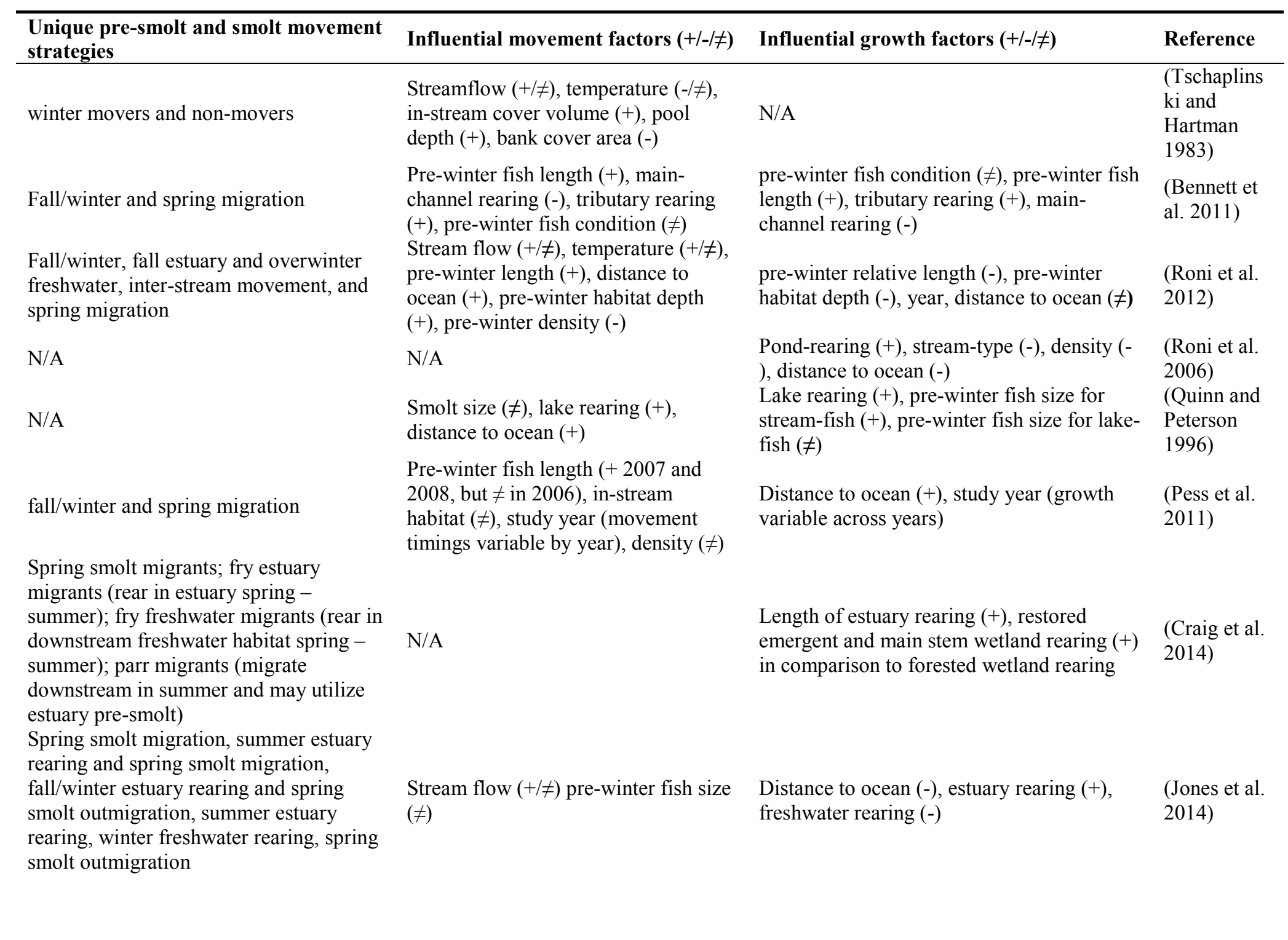




\begin{tabular}{|c|c|c|c|}
\hline $\begin{array}{l}\text { Unique pre-smolt and smolt movement } \\
\text { strategies }\end{array}$ & Influential movement factors $(+/-/ \neq)$ & Influential growth factors $(+/-/ \neq)$ & Reference \\
\hline $\begin{array}{l}\text { Natal stream reach, non-natal stream, } \\
\text { mobile (multiple streams) }\end{array}$ & Distance to non-natal stream (-) & $\begin{array}{l}\text { pre-winter fish weight }(+) \text {, movement to } \\
\text { intermittent upper watershed tributary }(+), \\
\text { streamflow }(-) \text {, stream temperature }(+), \\
\text { spawning density }(+)\end{array}$ & $\begin{array}{l}\text { (Ebersole et } \\
\text { al. 2006a) }\end{array}$ \\
\hline $\begin{array}{l}\text { Fall/winter (small number, personal } \\
\text { observation) and spring smolt migration }\end{array}$ & Distance to ocean $(+)$ & $\begin{array}{l}\text { Pre-winter fish length }(+) \text {, temperature }(+) \text {, } \\
\text { intermittent tributary rearing }(+) \text {, main- } \\
\text { channel rearing }(-) \text {, percent bedrock }(\neq) \text {, } \\
\text { black spot present }(\neq) \text {, spawner biomass }(\neq) \text {, } \\
\text { deciduous riparian canopy cover }(\neq), \\
\text { distance to ocean }(-)\end{array}$ & $\begin{array}{l}\text { (Ebersole et } \\
\text { al. 2009) }\end{array}$ \\
\hline $\begin{array}{l}\text { Fall/winter to estuary, fall estuary and } \\
\text { freshwater overwinter, spring migration }\end{array}$ & $\begin{array}{l}\text { Stream flow }(+/ \neq) \text {, distance to ocean } \\
(+), \text { salinity }(+)\end{array}$ & $\begin{array}{l}\text { Estuary ecotone rearing }(+) \text {, upper } \\
\text { watershed freshwater rearing }(-) \text {, distance to } \\
\text { ocean }(+)\end{array}$ & $\begin{array}{l}\text { (Miller and } \\
\text { Sadro 2003) }\end{array}$ \\
\hline Fall/winter and spring smolt migration & $\begin{array}{l}\text { Fall/winter movement and stream } \\
\text { flow }(+) \text {, pre-winter fish length*year } \\
(+/-) \text {, distance to ocean }(-)\end{array}$ & Movement season $(+/-)$ & $\begin{array}{l}\text { (Rebenack } \\
\text { et al. 2015) }\end{array}$ \\
\hline
\end{tabular}

